
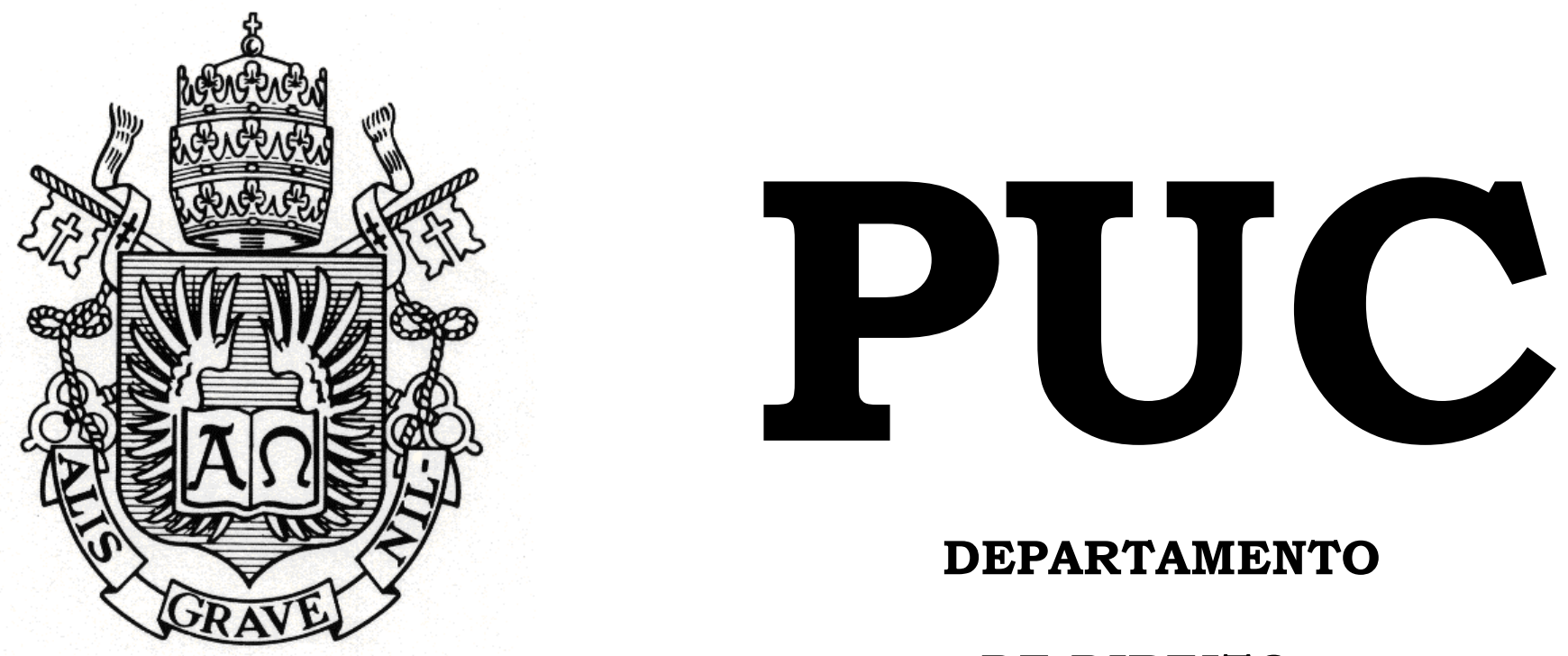

DEPARTAMENTO

DE DIREITO

\title{
A RESERVA FLORESTAL LEGAL NA LEGISLAÇÃO NACIONAL
}

por

MARIA VITÓRIA PALHARES

ORIENTADORA: ISABELLA FRANCO GUERRA 2012.1 


\title{
A RESERVA FLORESTAL LEGAL NA LEGISLAÇÃO NACIONAL
}

\author{
por

\section{MARIA VITÓRIA PALHARES}

Monografia apresentada ao

Departamento de Direito da Pontificia Universidade Católica do Rio de Janeiro (PUC-Rio) para a obtenção do Título de Bacharel em Direito.

Orientadora: ISABELLA FRANCO GUERRA 


\section{DEDICATÓRIA}

Ao meu querido avô Luis, por quem tenho grande admiração, que diante de sua tão empenhada dedicação na realização de sua profissão, inspirou-me na escolha desta formação intelectual. 


\section{AGRADECIMENTOS}

Meus mais sinceros agradecimentos aos meus pais, a quem devo minha vida e minha formação moral, pela credibilidade depositada em mim. Agradeço os anos de dedicação, o amor incondicional que me oferecem e o constante incentivo e apoio, essenciais para a conclusão deste caminho.

Agradeço aos meus irmãos, por estarem sempre ao meu lado, como exemplos e referências ao longo de toda à minha vida.

Aos meus amigos, por me encorajarem a seguir em frente.

À minha orientadora, Isabella Franco Guerra, pela assistência, atenção e preocupação dedicadas a este trabalho.

Ao corpo docente do curso do Direito da PUC-Rio por todos os ensinamentos transmitidos ao longo dos anos. 


\section{RESUMO}

A presente monografia busca enfatizar e reforçar a importância do instituto da Reserva Florestal Legal, como importante instrumento de proteção e preservação do meio ambiente.

A escolha do tema decorre do fato de que, apesar de atualmente a questão ambiental ser um dos temas mais evidentes nos debates internacionais acerca do futuro da humanidade, sendo o Brasil exemplo para os demais países no que tange à suas leis de proteção ambiental, o Código Florestal de 1965 foi revogado pela Lei nº. 12.651 de 25 de maio de 2012, sob o principal argumento de que suas normas inviabilizavam o desenvolvimento econômico do País.

Para tanto, analisa-se o regime jurídico ambiental, mais especificamente no que concerne à flora brasileira, concluindo-se ser a sua proteção essencial à concretização do direito fundamental ao meio ambiente ecologicamente equilibrado promovedor de sadia qualidade de vida humana, conforme previsão da Constituição Federal de 1988, incluindo-se nessa análise os princípios de Direito Ambiental como instrumentos de observância obrigatória na elaboração da legislação ambiental.

Destacam-se as disposições constitucionais que viabilizam a coexistência da proteção ambiental e do desenvolvimento econômico como comprovação de que a Reserva Florestal Legal não interfere neste último, sendo essencial à proteção do meio ambiente e, principalmente, da peculiar biodiversidade existente no território brasileiro.

Por fim, o regime jurídico da Reserva Florestal Legal é examinado minuciosamente, bem como as suas alterações introduzidas pelo novo Código Florestal, demonstrando que estas não condizem com o discurso brasileiro de redução das emissões de gases do efeito estufa através da preservação das florestas. 
Palavras chaves: Meio ambiente, direito fundamental, Código Florestal, Reserva Florestal Legal, Biodiversidade, desenvolvimento sustentável. 


\section{EPÍGRAFE}

“De uma coisa sabemos: a terra não pertence ao homem, é o homem que pertence à terra.

Disto temos certeza. Todas as coisas estão interligadas, como o sangue que une uma família. Tudo está relacionado entre si. Tudo quanto agride a terra, agride os filhos da terra. Não foi o homem quem teceu a trama da vida: ele é meramente um fio da mesma. Tudo que ele fizer à trama, a si próprio fará.”

Cacique Seattle

"O mundo tornou-se perigoso, porque os homens aprenderam a dominar a natureza antes de se dominarem a si mesmos." 


\section{SUMÁRIO}

Introdução

1. A importância da tutela ambiental

1.1. A preocupação com o bem ambiental

1.2. A proteção constitucional do meio ambiente

1.3. A importância das florestas para a qualidade de vida dos seres humanos

1.4. A proteção constitucional das florestas

1.4.1. Espaços territoriais especialmente protegidos

1.4.2. Competências constitucionais em matéria florestal

1.5. Os princípios constitucionais informadores do Direito Ambiental Brasileiro

1.5.1. Os princípios e a sua importância

1.5.2. Princípio da dignidade da pessoa humana

1.5.3. Princípio democrático, da participação e da informação

1.5.4. Princípio da função socioambiental da propriedade

1.5.5. Princípio do desenvolvimento sustentável

1.5.6. Princípio da precaução

1.5.7. Princípio da prevenção

1.5.8. Princípio do equilíbrio

2. A Reserva Florestal Legal

2.1. Previsão legal

2.2. Conceito

2.3. Percentuais de Reserva Florestal Legal 
2.3.1. Zoneamento Ecológico-Econômico

2.4. Localização das áreas de Reserva Florestal Legal

2.5. Regime de Manejo Florestal Sustentável

2.6. Registro da Reserva Florestal Legal no Cadastro Ambiental Rural

2.7. A Reserva Florestal Legal como obrigação

2.8. Recomposição, regeneração natural e compensação da Reserva Florestal Legal

2.8.1. Servidão Ambiental

2.8.2. Cota de Reserva Ambiental

3. O Código Florestal de 2012 - Lei nº 12.651 de 25 de maio de 2012

3.1. Implicações da Lei nº 12.651 de 25 de maio de 2012 nas áreas de Reserva Florestal Legal

3.2. Princípio da vedação ao retrocesso

4. Conclusão

5. Bibliografia 



\section{Introdução}

Percebe-se, atualmente, que a questão ambiental é tema recorrente no cenário econômico, social e político mundial, intimamente ligada à preocupação com o futuro da humanidade.

É certo que os recursos naturais disponíveis na natureza são essenciais para o desenvolvimento das atividades dos seres humanos, sendo, por esse motivo, por eles usufruídos indiscriminadamente. Não só os recursos naturais fornecidos pelo meio ambiente como também o próprio espaço por ele ocupado é alvo da ação antrópica ansiosa por desenvolver atividades majoritariamente econômicas.

Entretanto, os avanços científicos possibilitaram a constatação de que os recursos naturais são limitados e que o uso indiscriminado dos mesmos acarreta a sua exaustão, uma vez que não respeita a capacidade de resiliência da Terra. Do mesmo modo, constatou-se que a manutenção de um meio ambiente ecologicamente equilibrado é essencial para a qualidade de vida do ser humano, na medida em que mantém a qualidade do ar, da água, e etc.

Por esse motivo, a presente monografia procede à análise do instituto da Reserva Florestal Legal, diante de seu novo regime jurídico, instituído, recentemente, pela Lei $\mathrm{n}^{\circ}$. 12.651 de 25 de maio de 2012 que revogou o Código Florestal de 1965, buscando-se traçar um panorama comparativo entre tais normas e enfatizando a importância desse instituto como uma medida de resguardo da higidez do meio ambiente. As florestas existentes no território brasileiro são grandes responsáveis pela manutenção da qualidade da vida humana e, ainda assim, são alvos de intensas perturbações provocadas pelo próprio homem.

A Constituição de 1988 dedicou um capítulo exclusivo ao meio ambiente, prevendo diversos instrumentos e princípios de observância obrigatória tanto pelo Poder Público como pela coletividade na promoção de efetiva proteção e preservação da natureza.

Nesse sentido, o instituto da Reserva Florestal Legal tem como fundamento os princípios informadores do Direito Ambiental, tais como os previstos constitucionalmente, sendo um importante instrumento de proteção do meio ambiente ao impor restrições à utilização de parte das florestas existentes nos contornos das propriedades rurais. 
E é justamente por ser um instituto limitador do direito de propriedade, sofre, atualmente, severas críticas no sentido de que inviabilizaria o desenvolvimento econômico tão almejado pelo Brasil.

Tais críticas deram origem à tramitação de diversos projetos de lei que visam modificar a legislação florestal, especialmente no que tange às áreas de proteção ambiental, incluindo-se a Reserva Florestal Legal. Dentre tais projetos, destaca-se aqui o Projeto de Lei $\mathrm{n}^{\circ} .1 .876$ de 1999, transformado, após aprovação em ambas as casas do Congresso Nacional e sanção da Presidente da República, na lei ordinária nº 12.651 de 25 de maio de 2012, a qual revogou o Código Florestal de 1965.

Fala-se em sanção, pois apesar de alguns dispositivos do projeto em comento terem sido vetados pela Presidente, o que enseja a apreciação de tais vetos pelo Congresso Nacional, nenhum deles interfere no regime jurídico da Reserva Florestal Legal. Portanto, o presente trabalho é elaborado com base no novo Código Florestal instituído no corrente ano.

Assim sendo, para o exame do referido instituto esta monografia está estruturada em três capítulos.

O primeiro deles trata da proteção constitucional concedida ao bem ambiental. Para tanto, discorre sobre a importância do meio ambiente e sua respectiva tutela constitucional para depois apresentar a importância das florestas para a concretização do direito ao meio ambiente ecologicamente equilibrado, a qual também possui tutela constitucional. Como finalização do capítulo, há a exposição de alguns princípios constitucionais informadores do Direito Ambiental que se relacionam direta ou indiretamente com o tema central deste trabalho.

O segundo capítulo cuida especialmente das áreas da Reserva Florestal Legal como um dos instrumentos viabilizadores da preservação e conservação da flora e da biodiversidade brasileiras, destacando-se a sua previsão legal, conceito e demais características.

Por fim, o terceiro capítulo analisa as modificações introduzidas pela Lei $n^{0} .12 .651$ de 25 de maio de 2012 somente no que concerne à Reserva Florestal Legal, que, conforme será demonstrado, ao alterar o regime jurídico desse instituto trouxe implicações em âmbito social e econômico. 


\section{A Importância da Tutela Ambiental}

\subsection{A preocupação com o bem ambiental}

Os debates sobre a importância do meio ambiente e a necessidade de sua proteção são, atualmente, nítidos e constantes tanto em âmbito internacional como nacional. Esta é uma questão de extrema relevância, mas que gera grandes conflitos de difícil solução, sendo o principal deles a falsa dicotomia existente entre desenvolvimento econômico/progresso social e proteção ambiental.

É cediço que o homem sempre utilizou os recursos naturais para a sua sobrevivência e desenvolvimento de suas atividades. Entretanto, tal utilização poderia ser caracterizada como abundante, excessiva, na medida em que a natureza era vista apenas como um instrumento capaz de atender às necessidades humanas.

Com o progresso da ciência e o desenvolvimento de diversos estudos versando sobre o meio ambiente, tornou-se necessário modificar a visão que o homem possuía acerca da natureza. Concluiu-se que os padrões de consumo e de exploração dos recursos naturais são capazes de causar grandes degradações ambientais com graves consequências, como o fim de tais recursos, a poluição do ar, a extinção de espécies, bem como o aumento das desigualdades sociais.

Aquela visão antropocêntrica, que considera que o centro do Universo é o ser humano e que por isso a natureza é apenas um instrumento de promoção do seu bem-estar, não deve ser considerada como unânime ou incontestável. Ao revés, deve-se ceder lugar à visão ecocêntrica, que reconhece na natureza um valor próprio, intrínseco, independente do papel que representa para o ser humano e que, portanto, é merecedora de proteção.

Edis Milaré ao discorrer sobre o assunto observa que a visão antropocêntrica angaria cada vez mais desafetos e antiadeptos e explica que a passagem da visão antropocêntrica para a visão ecocêntrica se deu depois de longos processos de mudança. ${ }^{1}$

A concessão de valor intrínseco à natureza não pretende anular o valor do ser humano, mas sim despertar a consciência de que enquanto atores de um mesmo cenário, homem e natureza devem coexistir, de forma harmônica, cabendo, então, àquele adotar posturas éticas em prol do meio ambiente, sem se limitar à concepção de que a natureza é mero instrumento

\footnotetext{
${ }^{1}$ MILARÉ, Édis. Direito do ambiente: a gestão ambiental em foco: doutrina, jurisprudência, glossário. $7^{\mathrm{a}}$ ed. São Paulo: Revista dos Tribunais, 2011. p. 114-115.
} 
necessário à satisfação de suas necessidades. ${ }^{2}$

A formação da conscientização ambiental surge, então, após a percepção de que a capacidade humana de transformar a natureza através da fruição ilimitada, excessiva e abundante dos recursos naturais gera significativos impactos ao meio ambiente não só deteriorando a natureza em si, ao alterar processos ecológicos, mas também a sua própria qualidade de vida, ao deteriorar o seu habitat, qual seja o planeta Terra.

A preocupação com o meio ambiente deve justificar-se, portanto, não só pelas perturbações que a sua degradação ocasiona a toda a humanidade, mas também pelas consequências da simples deterioração do meio em si, visto que a natureza possui valor intrínseco e deverá ser conservada e preservada inclusive em prol das futuras gerações.

Percebe-se, ainda, que os impactos ambientais gerados pela utilização do meio ambiente transcendem as fronteiras dos países, atingindo todos os seres que habitam o planeta e, por isso, a adoção de uma postura ética, de respeito à natureza, deverá ser adotada por toda a humanidade.

Nesse sentido, observa Leonardo Boff:

"Para viverem como humanos, os homens e as mulheres precisam criar certo consensos, coordenar certas ações, coibir certas práticas e elaborar expectativas e projetos coletivos. (...) Hoje as relações são extremamente complexas. Postula-se uma referência para a totalidade dos seres humanos, habitantes do mesmo planeta, que agora se descobrem como espécie, interdependentes, vivendo numa mesma casa e com um destino comum. Se não criarem um acordo quanto a exigências éticas e morais mínimas, como poderão coexistir pacificamente, preservar o lar comum e garantir um futuro para todos?"3

A degradação ambiental pode ocorrer de diversos modos, atingindo o meio ambiente como um todo ou cada elemento que o integra.

Nesse sentido, a situação da flora brasileira merece destaque, uma vez que o ritmo de sua destruição permanece acelerado em prol das ameaças formadas pela extração ilegal de madeira e pelo uso alternativo do solo principalmente para a formação de pastagens e plantios agrícolas. O desmatamento é fator de maior preocupação dos ambientalistas porque ocasiona a descaracterização total do meio ambiente, envolvendo um impacto ambiental muito acentuado com consequências não tão conhecidas.

Segundo a publicação pelo Instituto Brasileiro de Geografia e Estatística - IBGE dos Indicadores de Desenvolvimento Sustentável de 2010, o Brasil está incluído em um grupo de

\footnotetext{
${ }^{2}$ COSTA NETO, Nicolao Dino de Castro e. Proteção Jurídica do Meio Ambiente - I Florestas. Belo Horizonte: Del Rey, 2003. p. 31.

${ }^{3}$ BOFF, Leonardo. Ethos Mundial: um consenso mínimo entre os humanos. Rio de Janeiro: Record,2009.p.29.
} 
doze países que abrigam 70\% (setenta por cento) da biodiversidade total do planeta. ${ }^{4}$ As espécies encontradas no território brasileiro estão abrigadas em seus mais diversos biomas, tais como a Floresta Amazônica, a Mata Atlântica e o Cerrado.

Entretanto, o processo de desflorestamento acentuou-se nas últimas décadas por conta, principalmente, do desenvolvimento da atividade agropecuária, o que provoca a extinção tanto das espécies animais quanto das vegetais, com a consequente diminuição da biodiversidade brasileira.

No mesmo estudo citado acima, o IBGE divulga que o desflorestamento da região amazônica já atingiu o patamar de 15\% (quinze por cento) de sua área total, enquanto que o cerrado já possui metade de sua área deteriorada pela ação antrópica. ${ }^{5}$ A situação da Mata Atlântica é ainda mais preocupante, visto que os dados divulgados em maio deste ano pelo Instituto Nacional de Pesquisas Espaciais (INPE) indicam que restam apenas 7,9\% da mata original deste bioma. ${ }^{6}$

É nesse cenário de crescente degradação ambiental, quando as consequências nocivas das atividades humanas já são passíveis de percepção e merecedoras de mudanças urgentes e inevitáveis ${ }^{7}$ que as leis ambientais são introduzidas no ordenamento jurídico brasileiro com o escopo de proteger o meio ambiente, garantindo a sadia qualidade do ser humano, e, simultaneamente, de impor limitações às suas ações.

Surge, então, um novo ramo dentro do Direito, denominado de Direito Ambiental, que buscará promover a máxima proteção possível ao meio ambiente, garantindo o direito do ser humano de viver em um ambiente equilibrado, promovedor de saúde e qualidade de vida, ao mesmo tempo em que regula a atividade humana em prol de seu próprio bem.

Ressalta-se que ao regular a atividade humana de modo a evitar a ocorrência de impactos ambientais, o Direito Ambiental não visa frear o desenvolvimento e o progresso econômico, mas sim possibilitar a ocorrência deste em harmonia com a natureza, contribuindo para a perpetuação tanto da espécie humana como das demais espécies animais e vegetais, sem permitir que os recursos naturais se esgotem causando prejuízos à vida das

\footnotetext{
4 Indicadores de Desenvolvimento Sustentável 2010. IBGE. p. $137 . \quad$ Disponível em http://www.ibge.gov.br/home/geociencias/recursosnaturais/ids/ids2010.pdf Acesso em 25 de maio de 2010.

5 Indicadores de Desenvolvimento Sustentável 2010. IBGE. p. 82, 89 e 96. Disponível em http://www.ibge.gov.br/home/geociencias/recursosnaturais/ids/ids2010.pdf Acesso em 25 de maio de 2012.

${ }^{6}$ Bioma Mata Atlântica encolheu 13 mil hectares. O Eco. Disponível em http://www.oeco.com.br/noticias/26057-biomamata-atlantica-encolheu-13-mil-hectares Acesso em 30 de maio de 2012.

${ }^{7}$ GRANZIERA. Maria Luiza Machado. Direito Ambiental. $2^{a}$ ed. São Paulo: Atlas, 2011. P.5
} 
gerações futuras.

O Direito Ambiental busca, então, harmonizar a relação homem-meio ambiente e, para tanto, é composto por um conjunto de normas e princípios informadores que protegem o meio ambiente e/ou impõe limitações às atividades humanas para a efetivação dessa proteção.

Nos dizeres de Maria Luiza Machado Granziera,

“o Direito Ambiental, assim, constitui o conjunto de regras jurídicas de direito público que norteiam as atividades humanas, ora impondo limites, ora induzindo comportamentos por meio de instrumentos econômicos, com o objetivo de garantir que essas atividades não causem danos ao meio ambiente, impondo-se a responsabilização e as consequentes sanções aos transgressores dessas normas.” 8

\subsection{A Proteção Constitucional do Meio Ambiente}

A Constituição Federal de 1988 é a lei suprema do ordenamento jurídico brasileiro, o que significa dizer que todos os demais atos normativos devem dela derivar e com ela acordar, sob pena de serem considerados inconstitucionais. Esta é a orientação contida no Princípio da Supremacia da Constituição, que traduz, em outras palavras, que a Constituição Federal, enquanto norma primeira, valida os demais atos normativos presentes no ordenamento jurídico brasileiro, ocupando grau máximo na relação hierárquica existente entre eles. ${ }^{9}$

Desta forma, como não poderia ser diferente, é ela a principal fonte do Direito Ambiental, a qual dedica um capítulo exclusivo para o meio ambiente, sem deixar de mencioná-lo e destacá-lo em diversos outros dispositivos, transparecendo o constituinte que a sua atuação esteve sempre norteada pelo princípio da preservação e proteção ambiental.

O artigo 225 da Constituição Federal de 1988 inaugura o capítulo destinado à tutela do meio ambiente e seu caput assim dispõe:

"Todos têm direito ao meio ambiente ecologicamente equilibrado, bem de uso comum do povo e essencial à sadia qualidade de vida, impondo-se ao Poder Público e à coletividade o dever de defendêlo e preservá-lo para as presentes e futuras gerações.”

Paulo de Bessa Antunes observa que são impostos ao Poder Público e à coletividade dois deveres distintos: 1) não promover a degradação do meio ambiente; e 2) promover a sua recuperação ${ }^{10}$, somados, ao fator futuro, que é o interesse das próximas gerações. Percebe-se, então, que o direito ao meio ambiente é um direito difuso, que a todos pertence, Poder Público e coletividade, incluindo-se, ainda, as futuras gerações. Todos aqueles que utilizam

\footnotetext{
${ }^{8}$ GRANZIERA. Maria Luiza Machado. Direito Ambiental. $2^{\mathrm{a}}$ ed. São Paulo: Atlas, 2011. p. 6.

${ }^{9}$ LENZA, Pedro. Direito Constitucional Esquematizado. 14 a ed. São Paulo: Saraiva, 2010. p. 195.

${ }^{10}$ ANTUNES, Paulo de Bessa. Direito Ambiental. $12^{\mathrm{a}}$ ed. Rio de Janeiro: Lumen Juris, 2010. p. 67.
} 
recursos naturais possuem a obrigação de zelar pelo meio ambiente, sem prejudicar os interesses das gerações futuras, que também possuem o direito ao meio ambiente ecologicamente equilibrado.

Constata-se ainda pelo disposto no citado artigo que o direito ao meio ambiente foi erigido à categoria de direito fundamental, reconhecendo-se a sua extrema relevância no âmbito jurídico brasileiro como uma extensão do direito à vida, uma vez que este não se resume somente ao direito de estar vivo e sim, também, de ter uma vida saudável.

Caracteriza-se como um direito humano de terceira geração ${ }^{11}$ e, diferentemente dos direitos e deveres individuais e coletivos, previstos no artigo $5^{\circ}$ da Constituição Federal de 1988, é um direito fundamental constitucional que não é destinado apenas aos "brasileiros e aos estrangeiros residentes no País”, mas sim a todos os indivíduos indistintamente. ${ }^{12}$

Paulo de Bessa Antunes explica que "todos, tal como presente no artigo 225, tem o sentido de qualquer indivíduo que se encontre em território nacional, independente de sua condição jurídica perante o nosso ordenamento jurídico.”13

Com a inclusão de todo e qualquer ser humano no rol daqueles que possuem tal direito, sem fazer qualquer distinção entre eles, o constituinte originário comprovou, mais uma vez, a grande importância do meio ambiente para a perpetuação da vida humana e, consequentemente, a relevância de termos um ramo do direito especializado na sua proteção.

Além disso, a lei fundamental considera o meio ambiente como um bem de uso comum do povo, “portanto é bem que não está na disponibilidade particular de ninguém nem de pessoa privada, nem de pessoa pública.” ${ }^{14}$ Daí decorre a ideia de que o direito ao meio ambiente equilibrado é um direito difuso ${ }^{15}$, o que significa dizer, novamente, que a todos pertence, sem que seja passível de individualização.

Portanto, mesmo que determinado bem ambiental esteja sob o domínio privado, é possível, com base constitucional, impor limitações ao uso, gozo e fruição desse bem, com

\footnotetext{
${ }^{11}$ STF, ADI no. 3540/DF, Relator Ministro Celso de Mello, Brasília, 01 de setembro de 2005: "Todos têm direito ao meio ambiente ecologicamente equilibrado. Trata-se de um típico direito de terceira geração (ou de novíssima dimensão), que assiste a todo gênero humano. Incumbe, ao Estado e à própria coletividade, a especial obrigação de defender e preservar, em benefício das presentes e futuras gerações, esse direito de titularidade coletiva e de caráter transindividual.”

${ }^{12}$ Constituição Federal de 1988, artigo 5º caput: "Todos são iguais perante a lei, sem distinção de qualquer natureza, garantindo-se aos brasileiros e aos estrangeiros residentes no País, a inviolabilidade do direito à vida, à liberdade, à igualdade, à segurança e à propriedade, nos termos seguintes: (...)”

${ }^{13}$ ANTUNES, Paulo de Bessa. Direito Ambiental. 12 a ed. Rio de Janeiro: Lumen Juris, 2010. p. 65.

${ }^{14}$ SILVA, José Afonso da. Direito Ambiental Constitucional.9a ed. São Paulo: Malheiros, 2011. p. 55.

${ }^{15}$ O Código de Defesa do Consumidor apresenta o conceito de direito difuso em seu artigo 81, parágrafo único, inciso I, que assim estabelece: "Interesse ou direitos difusos, assim entendidos para efeitos deste Código, os transindividuais, de natureza indivisível, de que sejam titulares pessoas indeterminadas e ligadas por circunstâncias de fato.”
} 
fulcro também no princípio da supremacia do interesse público sobre o interesse privado, que vigora no ordenamento jurídico brasileiro norteando toda e qualquer atuação do Poder Público. ${ }^{16}$

Compreende-se o meio ambiente, conforme definido na Lei 6.938 de 31 de agosto de 1981, que dispõe sobre a Política Nacional do Meio Ambiente, como “o conjunto de condições, leis, influências e interações de ordem física, química e biológica, que permite, abriga e rege a vida humana em todas as suas formas”. ${ }^{17}$

Extrai-se deste conceito legal que o meio ambiente pode ser considerado como um macrobem ou como microbens isolados, conforme nos ensina Maria Luiza Machado Granziera:

"macrobem - à medida que consiste em um todo a ser protegido de forma holística e que pode traduzir-se no patrimônio ambiental -, possui forte conteúdo de abstração, ao contrário dos elementos que o compõem - microbens -, esses bastante concretos (uma floresta, uma espécie rara, um manancial), possuidores de regime jurídico próprio, de acordo com a suas características." ${ }^{\text {18 }}$

Assim, para a garantia de um "meio ambiente ecologicamente equilibrado", a Constituição Federal prevê diversos instrumentos que abrangem tanto a defesa do meio ambiente considerado como um todo (macrobem), quanto de cada bem ambiental que o compõe (microbens), como por exemplo, as florestas, que por serem elementos integrantes do meio ambiente também gozam de proteção jurídica constitucional.

\subsection{A importância das florestas para a qualidade de vida dos seres humanos}

A floresta, como elemento integrante do meio ambiente, desempenha papel fundamental para a manutenção da vida de diversas espécies, dentre elas o ser humano. Juntamente com a sua vegetação, seus animais, tipo de solo e clima, as florestas formam ecossistemas que, por sua vez, formam a biosfera, que é o conjunto de regiões do planeta em condições de sustentar a vida de forma permanente. ${ }^{19}$

Rogério da Cruz Caradori afirma que as florestas

"sempre estiveram presentes em nossas vidas, desde o surgimento de nossa espécie, seja fornecendo alimento para nossa própria subsistência, seja fornecendo matéria-prima para a construção de abrigos e

\footnotetext{
${ }^{16}$ Nesse sentido, ver DI PIETRO, Maria Sylvia Zanella. 25a ed. Direito Administrativo. São Paulo: Atlas, 2012. p. 65-68

${ }^{17}$ Lei ${ }^{\circ}$. 6.938 de 31-08-1981, artigo $3^{\circ}$, inciso I.

${ }^{18}$ GRANZIERA, Maria Luiza Machado. Direito Ambiental. $2^{\mathrm{a}}$ ed. São Paulo: Atlas, 2011. p. 7.

${ }^{19}$ LINHARES, Sérgio; GEWANDSZNAJDER, Fernando. Biologia hoje: volume 3. 10ª ed. São Paulo: Ática, 1999. p. 241 e 242.
} 
também, desde há muito tempo atrás, matéria-prima para o beneficiamento de produtos presentes em nosso dia a dia, tanto para um simples ato de conforto ou para a cura de muitas doenças.” ${ }^{20}$

Constata-se, então, que a manutenção de áreas florestais é fundamental para a sobrevivência da humanidade e demais formas de vida e que, consequentemente, necessita da proteção jurídica do Direito Ambiental como instrumento de concretização do direito fundamental ao meio ambiente ecologicamente equilibrado, garantido constitucionalmente. ${ }^{21}$

Ante a inexistência na legislação brasileira de um conceito jurídico normativo para o termo florestas, destaca-se aqui a definição trazida pelo dicionário Houaiss: “denso conjunto de árvores que cobrem vasta extensão de terra.”22

Este conceito traz em si uma função ecológica primordial desempenhada por esse ecossistema, que é a cobertura do solo, também destacada pelo revogado Código Florestal de 1965, Lei 4.771 de 15 de Setembro de 1965 e mantida pela Lei ${ }^{\circ}$. 12.651 de 25 de maio de 2012, ao reconhecerem às florestas e às demais formas de vegetação utilidade para o solo que revestem:

"As florestas existentes no território nacional e as demais formas de vegetação nativa, reconhecidas de utilidade às terras que revestem, são bens de interesse comum a todos os habitantes do País, exercendo-se os direitos de propriedade com as limitações que a legislação em geral e especialmente este Lei estabelecem.” 23

A floresta atua, então, como principal protetora do solo. A sua substituição por culturas ou pastagens expõe a superfície terrestre à ação de agentes naturais, como os ventos e as chuvas, responsáveis pelo processo de erosão, que, apesar de ser um fenômeno natural, tem intensidade variável determinada por diversos fatores, tal como a cobertura vegetal. A supressão desta pelo homem intensifica o processo de erosão, ocasionando desequilíbrios ambientais que resultarão em desmoronamentos e assoreamentos de rios d'água, além de diminuir a infiltração de água no solo para abastecimento dos reservatórios subterrâneos, uma vez que, desprovido da proteção de sua vegetal natural, o escoamento superficial das águas das chuvas aumenta, elevando o nível dos rios. ${ }^{24}$

\footnotetext{
${ }^{20}$ CARADORI, Rogério da Cruz. O Código Florestal e a legislação extravagante: teoria e prática da proteção florestal. São Paulo: Atlas, 2009. p. 2.

${ }^{21}$ ANTUNES, Paulo de Bessa. Direito Ambiental. 12 a ed. Rio de Janeiro: Lumen Juris, 2010. p. 495.

${ }^{22}$ HOUAISS, Antônio; VILLAR, Mauro de Salles. Dicionário Houaiss da Língua Portuguesa. $1^{\text {a }}$ ed. Rio de Janeiro: Objetiva, 2001.

${ }^{23}$ Lei $n^{\circ}$. 4.771/1965, artigo $1^{\circ}$, caput (revogado). Lei $n^{\circ} 12.651 / 2012$, artigo $1^{\circ}$-A, §2 ${ }^{\circ}$.

${ }^{24}$ SANCHÉZ, Luis Enrique. Avaliação de impacto ambiental: conceito e métodos. São Paulo: Oficina de Textos, 2008. p. 35 e 36.
} 
Outro papel fundamental desempenhado pelas florestas é a manutenção da biodiversidade. Elas são responsáveis por abrigarem a fauna e, como seres vegetais que são, produzem, através da fotossíntese (processo de transformação de dióxido de carbono, água e sais minerais em compostos orgânicos e oxigênio com o aproveitamento da luz solar) os compostos orgânicos que servirão de alimento a todos os outros seres vivos. ${ }^{25}$

Cumpre destacar aqui que a biodiversidade brasileira é das mais complexas, tal é a sua magnitude, sendo o Brasil um país peculiar quando se fala em natureza, privilegiado por sua riqueza de espécies.

Não obstante, consomem o gás carbônico produzido pela respiração e pela decomposição transformando-o em substância orgânica. Entretanto, como se sabe, as atividades desenvolvidas pela humanidade também liberam gás carbônico na atmosfera e em velocidade muito mais rápida do que a capacidade de assimilação deste gás pela fotossíntese, causando assim um desequilíbrio no ciclo do carbono. A destruição das florestas por si só é capaz de gerar tal desequilíbrio, ocasionando, consequentemente, um aumento progressivo de gás carbônico na atmosfera. ${ }^{26}$

O efeito estufa e o aquecimento global, temas recorrentes nos debates mundiais sobre meio ambiente, encontram justificativas na presença desse e outros gases em excesso na atmosfera. Isto porque contribuem para a formação de uma barreira que retém na superfície terrestre o calor irradiado pela luz solar, aumentando, assim, a temperatura do planeta.

Este aumento de temperatura pode provocar a elevação do nível de água dos oceanos, devido à expansão térmica da água, e também devido ao derretimento das calotas polares, constatando-se, então, que as florestas são também importantes para o controle do clima das regiões.

Conclui-se, portanto, que todos os elementos integrantes do meio ambiente estão sistematicamente conectados, o que faz com que a alteração de um deles influencie todos os demais.

\footnotetext{
${ }^{25}$ LINHARES, Sérgio; GEWANDSZNAJDER, Fernando. Biologia hoje: volume 3. $10^{\mathrm{a}}$ ed. São Paulo: Ática, 1999. p. 247.

${ }^{26}$ LINHARES, Sérgio; GEWANDSZNAJDER, Fernando. Biologia hoje: volume 3. 10a ed. São Paulo: Ática, 1999. p. 264 a 266.
} 
Por fim, as florestas desempenham também um papel econômico fundamental, pois, para muitos países, são fontes de atividades econômicas, como é o caso do Brasil, onde já há inúmeras leis destinadas à regulamentar esse tipo de exploração florestal. ${ }^{27}$

As florestas são, então, essenciais à manutenção da vida, pois nos dizeres de Paulo Affonso Leme Machado

“conscientes estamos de que sem as florestas não haverá água, não haverá fertilidade do solo, a fauna depende da floresta e nós -seres humanos - sem florestas não vivemos. As florestas fazem parte de ecossistemas, onde os elementos são interdependentes e integrados.” 28

\subsection{A Proteção Constitucional das Florestas}

A flora, como bem ambiental integrante do meio ambiente, goza de proteção jurídica constitucional e consiste no conjunto de todas as espécies vegetais que cobrem o território nacional. Ela é o gênero, do qual as florestas, os mangues, cerrados, caatingas, dentre outros, são espécies. $^{29}$

Como proteção jurídica concedida à flora, prevê o artigo 225, §1 ${ }^{\circ}$, inciso VII da Constituição Federal de 1988 que incumbe ao Poder Público proteger a flora, vedadas, na forma da lei, as práticas que coloquem em risco sua função ecológica ou que provoquem a extinção de espécies.

Além disso, o inciso III desse mesmo dispositivo constitucional determina como incumbência do Poder Público a definição de espaços territoriais a serem protegidos, sendo a alteração e a supressão somente mediante lei e vedada qualquer utilização que comprometa a integridade dos atributos que justifiquem sua proteção.

\subsubsection{Espaços territoriais especialmente protegidos}

A previsão constitucional desses espaços se justifica como uma medida de efetivação do direito ao meio ambiente ecologicamente equilibrado, previsto no caput do artigo 225 da Constituição Federal de 1988. A Lei 6.938/1981 também faz menção expressa a tais espaços como instrumentos da Política Nacional do Meio Ambiente. ${ }^{30}$

\footnotetext{
${ }^{27}$ ANTUNES, Paulo de Bessa. Direito Ambiental. 12ª ed. Rio de Janeiro: Lumen Juris, 2010. p. 496.

${ }^{28}$ MACHADO, Paulo Affonso Leme. Direito Ambiental Brasileiro. 14 ${ }^{\circ}$ ed. São Paulo: Malheiros. 2006. p. 721.

${ }^{29}$ SILVA, José Afonso da. Direito Ambiental Constitucional. 9a edição. São Paulo: Malheiros, 2011. p. 168.

${ }^{30}$ Lei 6.938 de 31 de agosto de 1981, artigo 9º, inciso VI, com redação dada pela Lei 7.804 de 18 de julho de 1989.
} 
Entretanto, ambas as normas não trazem uma definição jurídica do que são os espaços territoriais especialmente protegidos, sendo necessário recorrer à doutrina para conceituá-los. Assim sendo, segundo José Afonso da Silva:

\begin{abstract}
"espaços territoriais especialmente protegidos são áreas públicas ou privadas (porção do território nacional) dotadas de atributos ambientais que requeiram sua sujeição, pela lei, a um regime jurídico de interesse público que implique sua relativa imodificabilidade e sua utilização sustentada, tendo em vista a preservação e proteção de integridade de amostras de todas a diversidade de ecossistemas, a proteção ao processo evolutivos das espécies, a preservação e proteção dos recursos naturais." ${ }^{31}$
\end{abstract}

Em sentido ecológico, os espaços territoriais especialmente protegidos juntamente com os seus componentes formam um ecossistema e, por esse motivo, são dignos de proteção especial, já que ecossistemas abrigam a biodiversidade. ${ }^{32}$

Na verdade, são diversos os fatores que ensejam a proteção dessa porção do território nacional, conforme afirma Maria Luiza Machado Granziera, que podem

“consistir nas características físicas ou bióticas de uma determinada área que, por sua relevância ambiental, ensejam um regime jurídico específico, ou simplesmente na necessidade de manutenção da cobertura vegetal do território brasileiro, como é o caso da reserva legal.”33

Verifica-se, portanto, que determinados espaços territoriais a serem definidos pelo Poder Público serão submetidos a um regime jurídico especial, decorrente da necessidade de preservação e conservação de atributos ambientais que são a eles inerentes.

Tal regime jurídico especial é um regime de interesse público e traduz uma dificuldade imposta pelo constituinte ao próprio Poder Público demarcador de espaços protegidos, posto que não poderá suprimi-los ou alterá-los sem o devido processo legislativo, o qual, segundo Paulo Affonso Leme Machado, garante “maior participação social para a decisão de manter ou suprimir a vegetação”. 34

Portanto, a Constituição Federal de 1988 não proíbe toda e qualquer utilização de tais espaços, mas sim aquela que comprometa a totalidade dos atributos ambientais que justificaram a sua proteção especial. E a alteração ou supressão dos mesmos somente poderá ocorrer mediante lei autorizativa.

Cumpre ressaltar ainda que a norma constitucional ao determinar a instituição de espaços territoriais especialmente protegidos não faz menção sobre o domínio dos mesmos, o

\footnotetext{
${ }^{31}$ SILVA, José Afonso da. Direito Ambiental Constitucional. 9a ed. São Paulo: Malheiros, 2011. p. 239.

${ }^{32}$ FERREIRA, Heline Sivini. Política Ambiental Constitucional. In: CANOTILHO, José Joaquim Gomes; LEITE, José Rubens Morato (Org.). Direito constitucional ambiental brasileiro. $4^{\text {a }}$ ed. São Paulo: Saraiva, 2011. p. 264.

${ }^{33}$ GRANZIERA, Maria Luiza Machado. Direito Ambiental. 2a ed. São Paulo: Atlas, 2011. p. 442.

${ }^{34}$ MACHADO, Paulo Affonso Leme. Direito ambiental brasileiro. 14 ed. São Paulo: Malheiros, 2006. p. 724.
} 
que nos resta compreender que são passíveis de demarcação tanto em áreas públicas quanto em áreas privadas. ${ }^{35}$

Mesmo tratando-se de áreas privadas, ainda assim se submeterão ao regime especial de interesse público, consistindo uma limitação ao exercício do direito de propriedade em virtude da supremacia desse interesse sobre o particular. ${ }^{36}$

Além disso, não há menção expressa também em relação aos tipos de vegetação que deverão estar incluídas nesses espaços e, por esse motivo, entende-se que toda e qualquer forma de vegetação que possua características fundamentais que justifiquem a criação desses espaços, qual seja, a preservação e conservação da biodiversidade, devem ser passíveis de proteção. ${ }^{37}$

Atualmente, em sentido amplo, podem-se definir os espaços territoriais especialmente protegidos como sendo as Áreas de Preservação Permanente, Reservas Florestais Legais e Unidades de Conservação.

Não obstante o dever constitucional imposto ao Poder Público de criar espaços de proteção ambiental, a própria Constituição Federal de 1988 em seu artigo 225, §4º , definiu que a "Floresta Amazônica brasileira, a Mata Atlântica, a Serra do Mar, o Pantanal MatoGrossense e a Zona Costeira são patrimônio nacional e sua utilização far-se-á, na forma da lei, dentro de condições que assegurem a preservação do meio ambiente, inclusive quanto ao uso de recursos naturais”.

Observa-se, enfim, que todas as disposições constitucionais pertinentes à proteção e preservação da flora transparecem a sua enorme importância para o meio ambiente e para a conservação da qualidade de vida do ser humano. Conforme nos ensina Maria Luiza Machado “a função ecológica da flora é, assim manter em equilíbrio as relações dos organismos entre si e com o meio físico. A flora é o elemento de ligação entre o solo, a fauna, o clima, a água e a umidade do ar.”38

\footnotetext{
${ }^{35}$ CARADORI, Rogério da Cruz. O Código Florestal e a legislação extravagante: a teoria e a prática da proteção florestal. São Paulo: Atlas, 2009. p. 20.

${ }^{36}$ GRANZIERA, Maria Luiza Machado. Direito Ambiental. 2a ed. São Paulo: Atlas, 2011. p. 443.

${ }^{37}$ CARADORI, Rogério da Cruz. O Código Florestal e a legislação extravagante: a teoria e a prática da proteção florestal. São Paulo: Atlas, 2009. p. 21.

${ }^{38}$ GRANZIERA, Maria Luiza Machado. Direito Ambiental. 2a ed. São Paulo: Atlas, 2011. p. 223.
} 


\subsubsection{Competências Constitucionais em Matéria Ambiental}

As competências em matéria ambiental estabelecidas pela Constituição Federal de 1988 seguem os mesmos princípios da repartição de competências em geral e são atribuídas a todos os entes que compõem a Federação. ${ }^{39}$ Destacam-se aqui apenas as competências que versam expressamente sobre a flora e as florestas.

Assim sendo, o artigo 23, inciso VII, prevê como competência comum da União, dos Estados, do Distrito Federal e dos Municípios a proteção do meio ambiente e preservação das florestas e da flora. Ressalta-se que o constituinte incluiu as florestas juntamente com a flora, o que não seria necessário, pois o conceito de flora abrange as florestas, sendo o gênero do qual esta espécie pertence.

Esta competência é comum, atribuída a todos os entes federativos, os quais irão exercê-la igualmente. Além disso, é denominada de competência material e, conforme nos ensina José Afonso da Silva, “é uma competência mais voltada para a execução das diretrizes, políticas e preceitos relativos à proteção ambiental.” ${ }^{40}$

Quanto à competência em matéria legislativa, dispõe o artigo 24, incisos VI, VII e VIII da Constituição Federal de 1988 que compete à União, aos Estados e ao Distrito Federal legislar sobre florestas, caça, pesca, fauna, conservação da natureza, defesa do solo e dos recursos naturais, proteção do meio ambiente e controle da poluição; sobre o patrimônio histórico, cultural, artísticos, turísticos e paisagísticos; e sobre responsabilidade por dano ao meio ambiente, ao consumidor, a bens e direitos de valor artístico, estético, histórico, turísticos e paisagístico.

Ressalta-se que tal competência é concorrente, ou seja, "prevê a possibilidade de disposição sobre determinada matéria por mais de um ente federativo" ${ }^{41}$, e apesar de os Municípios não estarem explicitamente aí incluídos, concede-se a eles também a competência para legislar sobre matéria ambiental por força do disposto no artigo 30, inciso II, da Constituição Federal de 1988, visto que é plausível reconhecer que nesse dispositivo “entra também a competência para suplementar a legislação federal e estadual na matéria.”42

\footnotetext{
${ }^{39}$ FERREIRA, Heline Silvini. Competências Ambientais. In: CANOTILHO, José Joaquim Gome; LEITE, José Rubens Morato (Orgs.) Direito Constitucional Ambiental Brasileiro. 4a ed. São Paulo: Saraiva, 2011. p. 228.

${ }^{40}$ SILVA, José Afonso da. Direito Ambiental Constitucional. $9^{a}$ ed. Malheiros: São Paulo, 2011. p. 79.

${ }^{41}$ FERREIRA, Heline Silvini. Competências Ambientais. In: CANOTILHO, José Joaquim Gome; LEITE, José Rubens Morato (Orgs.) Direito Constitucional Ambiental Brasileiro. 4a ed. São Paulo: Saraiva, 2011. p. 237.

${ }^{42}$ SILVA, José Afonso da. Direito Ambiental Constitucional. 9a ed. São Paulo: Malheiros, 2011. p. 82.
} 
No âmbito dessa competência concorrente, caberá, então, à União estabelecer normas gerais e aos demais entes federados normas suplementares de acordo com os interesses locais e dentro dos limites fixados pelas normas federais. ${ }^{43}$

\subsection{Os Princípios Constitucionais informadores do Direito Ambiental Brasileiro}

\subsubsection{Os princípios e a sua importância}

Dentre os diversos elementos formadores do direito, encontramos os princípios. Para o universo jurídico, os princípios são enunciados orientadores que integram e complementam a norma jurídica no momento de sua aplicação, bem como auxiliam e norteiam o legislador no momento de sua criação. ${ }^{44}$

Nesse sentido, dispõe o artigo $4^{\circ}$ da Lei de Introdução às normas do Direito Brasileiro (Decreto-Lei $\mathrm{n}^{\circ}$. 4.657 de 4 de Setembro de 1942) que “quando a norma jurídica for omissa, o juiz decidirá o caso de acordo com a analogia, os costumes e os princípios gerais de direito.”

As normas jurídicas, ainda que em constante transformação e adaptação, não são capazes de responder tão rapidamente aos reflexos das inovações tecnológicas nas relações humanas, o que geram demandas jurídicas que, por vezes, trazem situações de omissões e lacunas da lei e que, no momento de sua aplicação, precisam ser sanadas. Para tanto, o juiz poderá recorrer, dentre outros elementos integradores do direito, aos princípios. ${ }^{45}$

O Direito Ambiental, assim como os demais ramos do Direito, possui princípios próprios que conferem fundamento ao conteúdo das normas de proteção ao meio ambiente e, conforme preleciona Paulo de Bessa Antunes é “a partir deles que as matérias que ainda não foram objeto de legislação específica podem ser tratadas pelo Poder Judiciário e pelos diferentes aplicadores do Direito (...).” 46

Assim, os princípios ambientais encontram-se, em sua maioria, no texto constitucional, e a razão de ser desta inclusão é a necessidade de se conferir uma proteção mais eficaz aos bens por ele tutelados. ${ }^{47}$ É como nos dizeres de Miguel Reale que afirma que alguns

\footnotetext{
${ }^{43}$ GRANZIERA, Maria Luiza Machado. Direito Ambiental. 2a ed. São Paulo: Atlas, 2011. p. 90.

${ }^{44}$ REALE, Miguel. Lições Preliminares de Direito. $27^{\mathrm{a}}$ ed. São Paulo: Saraiva, 2002. p. 304

${ }^{45}$ REALE, Miguel. Lições Preliminares de Direito. $27^{a}$ ed. São Paulo: Saraiva, 2002. p. 304

${ }^{46}$ ANTUNES, Paulo de Bessa. Direito Ambiental. 12 a ed. Rio de Janeiro: Lumen Juris, 2010. p.21.

${ }^{47}$ GUERRA, Isabella Franco; LIMMER, Flávia C. Princípios Constitucionais Informadores do Direito Ambiental. In: PEIXINHO, Manoel Messias; GUERRA, Isabella Franco; NASCIMENTO FILHO, Firly (Orgs.). Os princípios da Constituição de 1988. Rio de Janeiro: Lumen Juris, 2006. p. 654.
} 
princípios são tão importantes que "o legislador lhe confere força de lei, com a estrutura de modelos jurídicos, inclusive no plano constitucional (...)”. 48

Destacam-se neste capítulo os princípios constitucionais informadores do Direito Ambiental que mais se aproximam do tema principal deste trabalho. Entretanto, considerando que o Direito Ambiental se encontra em formação e transformação, com constante atividade legislativa, a doutrina não é pacífica na enunciação e na denominação dos princípios que o integram, não sendo prudente, portanto, falar-se na existência de um rol taxativo de princípios ambientais.

\subsubsection{Princípio da Dignidade da Pessoa Humana}

Conforme previsão constitucional, a proteção ambiental visa manter o meio ambiente ecologicamente equilibrado, apto a conceder ao ser humano uma sadia qualidade de vida ${ }^{49}$, como um de seus direitos fundamentais. ${ }^{50}$

Observa-se, então, que o meio ambiente ecologicamente equilibrado é um dos atributos necessários para a promoção da sadia qualidade de vida do homem e que esta, por sua vez, é preocupação essencial do princípio da dignidade da pessoa humana, fundamento da República Federativa do Brasil. ${ }^{51}$ Portanto, resta claro que a existência de um meio ambiente ecologicamente equilibrado é elemento essencial à vida digna do ser humano, ou seja, é indispensável, imprescindível.

Nesse sentido, afirma Paulo de Bessa Antunes: “o direito estabelecido pelo artigo 225 da Constituição é fundado no princípio da dignidade da pessoa humana e somente nele encontra a sua justificativa final” ${ }^{52}$, e foi por este motivo que o constituinte originário erigiuo à categoria de direito constitucional fundamental.

A Conferência das Nações Unidas sobre o Homem e o Meio Ambiente, realizada em Estocolmo no ano de 1972 (Conferência de Estocolmo), serviu de inspiração para a redação do artigo 225 da Constituição Federal de 1988, visto que já consagrava o princípio da dignidade da pessoa humana como fundamento da necessidade de tutela ambiental em seu princípio 1, que assim preconiza:

\footnotetext{
${ }^{48}$ REALE, Miguel. Lições Preliminares de Direito. 27ª ed. São Paulo: Saraiva, 2002. p. 305.

${ }^{49}$ Constituição Federal de 1988, artigo 225, caput.

${ }^{50}$ SILVA, José Afonso da. Direito Ambiental Constitucional. 9a ed. São Paulo: Malheiros, 2011. p. 60.

${ }^{51}$ Constituição Federal de 1998, artigo $1^{\circ}$, inciso III.

52 ANTUNES, Paulo de Bessa. Direito Ambiental. 12a ed. Rio de Janeiro: Lumen Juris, 2010. p. 24.
} 
"O homem tem o direito fundamental à liberdade, à igualdade e ao desfrute de condições de vida adequadas, em um meio ambiente de qualidade tal que permite levar uma vida digna e gozar de bemestar, tendo a solene obrigação de proteger e melhorar o meio ambiente para as gerações presentes e futuras." 53

A Conferência das Nações Unidas sobre Meio Ambiente e Desenvolvimento, realizada no Rio de Janeiro no ano de 1992 (Conferência do Rio de Janeiro), também incluiu dentre os seus princípios a importância do direito ao meio ambiente equilibrado como requisito para a vida digna do ser humano: “Os seres humanos estão no centro das preocupações relacionados com o desenvolvimento sustentável. Têm direito a uma vida saudável e produtiva em harmonia com a natureza.”54

Portanto, conclui-se que o direito ao meio ambiente é um direito humano fundamental, constituindo-se um dos requisitos para que o ser humano alcance a sua dignidade, princípio norteador de todo o ordenamento jurídico brasileiro. O ser humano faz parte do meio ambiente e, neste sentido, a proteção ambiental inclui também a sua própria proteção. ${ }^{55}$

\subsubsection{Princípio democrático, princípio da participação e princípio da informação}

Os princípios da participação e da informação estão incluídos no princípio democrático, o qual, conforme nos ensina Paulo de Bessa Antunes,

"assegura aos cidadãos o direito de, na forma da lei ou regulamento, participar das discussões para a elaboração das políticas públicas ambientais e de obter informações dos órgãos públicos sobre matéria referente à defesa do meio ambiente e de empreendimentos utilizadores de recursos ambientais e que tenham significativas repercussões sobre o ambiente, resguardado o sigilo industrial.,"56

O direito à informação relaciona-se diretamente com o princípio da publicidade dos atos, recorrente no ordenamento jurídico brasileiro. A Constituição Federal de 1988 prevê que a Administração Pública deve obedecer ao princípio da publicidade ${ }^{57}$, o que garante a transparência de sua atuação e a divulgação, para a sociedade, de informações sobre as suas práticas.

\footnotetext{
53 Declaração de Estocolmo (1972), Princípio 1. Ministério do Meio ambiente. Disponível em www.mma.gov.br/estruturas/agenda21/_arquivos/estocolmo.doc. Acesso em 19 abril 2012.

${ }^{54}$ Declaração do Rio sobre Meio Ambiente e Desenvolvimento, Princípio 1. Ministério do Meio Ambiente. Disponível em www.mma.gov.br/sitio/index.php?ido=conteudo.monta\&idEstrutura=18\&idConteudo=576. Acesso em 19 abril 2012.

${ }_{55}$ GRANZIERA, Maria Luiza Machado. Direito Ambiental. 2a ed. São Paulo: Atlas, 2011. p. 56.

${ }^{56}$ ANTUNES, Paulo de Bessa. Direito Ambiental. $12^{\text {a }}$ ed. Rio de Janeiro: Lumen Juris, 2010. p. 26.

${ }^{57}$ Constituição Federal de 1988, artigo 37, caput.
} 
Prevê, ainda, no capítulo destinado aos direitos e deveres individuais e coletivos, que todos têm direito a receber informações dos órgãos públicos, “sob pena de responsabilidade, ressalvadas aquelas cujo sigilo seja imprescindível à segurança da sociedade e do Estado.”58

No âmbito ambiental, o princípio democrático, juntamente com os princípios da informação e da participação, decorre da previsão constitucional de que a proteção e preservação do meio ambiente é um dever tanto do Poder Público quanto de toda a coletividade. A transparência das políticas públicas ambientais é essencial para que os indivíduos possam de fato cumprir com esse dever estabelecido constitucionalmente, sendo a informação imprescindível para que atuem junto ao Poder Público na defesa do meio ambiente.

Para a concretização do direito à informação, foi editada a Lei $n^{0}, 10.650 / 2003$, que dispõe sobre o acesso público aos dados e informações existentes nos órgãos e entidades integrantes do SISNAMA (Sistema Nacional do Meio ambiente).

Os órgãos integrantes do SISNAMA, por força dessa lei, são obrigados a conceder ao público acesso aos documentos e processos administrativos que versem sobre matéria ambiental e a fornecer informações ambientais de que disponham, dando-se relevância a algumas matérias especificadas na lei. ${ }^{59}$

As informações acima referidas podem ser solicitadas por qualquer indivíduo, desde que apresente requerimento no qual assuma o comprometimento de não utilizá-las para fins comerciais. $^{60}$

Para facilitar a divulgação das informações ambientais, a Lei da Política Nacional do Meio Ambiente (Lei 6.938/1981) prevê em seu artigo 9º inciso VII, como um dos instrumentos do exercício dessa política, o SISNIMA - Sistema Nacional de Informações -, que reunirá todas as informações ambientais em um sistema de dados, servindo de base para o Poder Público e toda a coletividade nas tomadas de decisões.

A obrigatoriedade da prestação de informações pelo Poder Público é mais um instrumento de preservação e proteção do meio ambiente e da qualidade de vida do ser humano, conforme afirma Maria Luiza Machado Granziera ao dizer que o direito à

\footnotetext{
${ }^{58}$ Constituição Federal de 1988, artigo $5^{\circ}$, inciso XXXIII.

${ }^{59}$ Lei $\mathrm{n}^{\circ} .10 .650$ de 16-04-2003, artigo $2^{\circ}$, caput, incisos I a VIII.

${ }^{60}$ Lei $\mathrm{n}^{\circ} .10 .650$ de $16-04-2003$, artigo $2^{\circ}, \S 2^{\circ}$.
} 
informação “confirma-se como fator de proteção aos direitos do cidadão, em sua mais básica expressão: o direito à vida.",61

O princípio da participação está correlacionado ao princípio da informação, uma vez que a participação da coletividade só poderá ser afirmada se esta possuir informações suficientes a possibilitar a sua intervenção perante o Poder Público.

A Conferência do Rio de Janeiro (1992) faz menção expressa a ambos os princípios em seu princípio 10, quando afirma que:

"A melhor maneira de tratar questões ambientais é assegurar a participação, no nível apropriado, de todos os cidadãos interessados. No nível nacional, cada indivíduo terá acesso adequado às informações relativas ao meio ambiente de que disponham as autoridades públicas, inclusive informações acerca de materiais e atividades perigosas em suas comunidades, bem como a oportunidade de participar nos processos decisórios. Os Estados irão facilitar e estimular a conscientização e a participação popular, colocando as informações à disposição de todos. Será propiciado o acesso efetivo a mecanismos judiciais e administrativos, inclusive no que se refere à compensação e reparação de danos.",62

O direito ao meio ambiente ecologicamente equilibrado é um direito difuso, que não diz respeito especificamente a uma pessoa ou a um grupo de pessoas e sim a um número indeterminado de pessoas. Assim sendo, nada mais coerente do que viabilizar a participação de qualquer interessado nos procedimentos que interfiram direta ou indiretamente no meio ambiente, bem indispensável à sadia qualidade de vida do ser humano.

Nesse sentido, a Constituição brasileira de 1988 prevê diversos instrumentos que tornam os indivíduos aptos a participar da proteção ambiental. Dentre tais instrumentos podemos destacar o Estudo Prévio de Impacto Ambiental, que deverá ser público e submetido à audiência pública ${ }^{63}$; a Ação Popular, cuja legitimidade pertence a qualquer cidadão, conforme previsão do artigo 5º, inciso LXXIII e a Ação Civil Pública, que, apesar de somente poder ser proposta por determinadas pessoas jurídicas ou pelo Ministério Público, é um importante instrumento de proteção do meio ambiente. ${ }^{64}$

A participação popular nas políticas públicas ambientais também poderá ocorrer através de ONG’s (Organizações Não Governamentais) e OSCIP’s (Organizações da Sociedade Civil de Interesse Público). Estas últimas são assim qualificadas por receberem fomento estatal e possuem como uma de suas finalidades previstas na Lei 9.790/1999, artigo

\footnotetext{
${ }^{61}$ GRANZIERA, Maria Luiza Machado. Direito Ambiental. 2a ed. São Paulo: Atlas, 2011. p. 68.

${ }^{62}$ Declaração do Rio sobre Meio Ambiente e Desenvolvimento. Ministério do Meio Ambiente. Disponível em www.mma.gov.br/sitio/index.php?ido=conteudo.monta\&idEstrutura=18\&idConteudo=576. Acesso em 19 abril 2012 .

${ }^{63}$ Constituição Federal de 1988, artigo 225, §1º, inciso IV.

${ }^{64}$ Constituição Federal de 1988, artigo 129, inciso III; Lei nº. 7.347 de 24-7-1985.
} 
$3^{\circ}$, inciso VI, a defesa, preservação e conservação do meio ambiente e promoção do desenvolvimento sustentável.

A atuação dessas organizações justifica-se pelo fato de que a participação de uma pessoa jurídica criada exclusivamente com o intuito de proteger e preservar o meio ambiente certamente terá mais força do que a participação de indivíduos isolados. Entretanto, Paulo Affonso Leme Machado observa que elas só serão eficazes "se tiverem credibilidade moral, pluralidade e idoneidade na sua composição (...).” 65

\subsubsection{Princípio da Função Socioambiental da Propriedade}

A Constituição Federal de 1988 dispõe em seu artigo 5º inciso XXII, que "é garantido o direito de propriedade” e, logo em seguida, no inciso XXIII deste mesmo artigo, estabelece que "a propriedade atenderá à sua função social." ${ }^{66}$

Constata-se, então, que a propriedade está condicionada ao cumprimento de sua função social, não podendo mais ser considerada como um direito absoluto. Ademais, há diversas limitações previstas no ordenamento jurídico brasileiro que poderão ser impostas ao seu exercício. ${ }^{67}$ Conforme nos ensina José Afonso da Silva, "limitações ao direito de propriedade consistem nos condicionamentos que atingem os caracteres tradicionais desse direito, pelo que era tido como direito absoluto, exclusivo e perpétuo." ${ }^{\text {„68 }}$

Entretanto, a exigência constitucional de que a propriedade deverá cumprir a sua função social não se caracteriza como uma limitação externa a esse direito, uma vez que as limitações relacionam-se com o exercício do direito, enquanto que a função social relacionase com a propriedade em si mesma, integrando o seu conteúdo como necessária à sua conceituação e reconhecimento legal. ${ }^{69}$

Nesse contexto, esta exigência constitucional representa uma evolução no conceito de propriedade. O que antes era um bem de interesse meramente privado e de utilização livre e

\footnotetext{
${ }^{65}$ MACHADO, Paulo Affonso Leme. Direito Ambiental Brasileiro. 14 a ed. São Paulo: Malheiros, 2006. p. 91.

${ }^{66}$ Constituição da República Federativa do Brasil de 1988, artigo 5º incisos XXII e XXIII.

${ }^{67}$ Entendimento pacificado nos tribunais brasileiros, a exemplo do Tribunal de Justiça do Rio de Janeiro, que assim decidiu no julgamento do Agravo de Instrumento 0004469-70-2012.8.19.0000, Desembargador Elton Leme. Rio de Janeiro, 16 de fevereiro de 2012: “(...) há muito esse direito perdeu o caráter individualista absoluto e passou a ser condicionado a deveres atrelados ao interesse da coletividade e às regras de harmonioso convício social.”

${ }^{68}$ SILVA, José Afondo da. Curso de Direito Constitucional Positivo. 27ª ed. São Paulo: Malheiros, 2006. p. 279.

${ }^{69}$ SILVA, José Afondo da. Curso de Direito Constitucional Positivo. 27 ed. São Paulo: Malheiros, 2006. p. 281 e 282.
} 
plena, hoje é um bem também de interesse público, que se configura como a obrigação de gerar benefícios e ao mesmo tempo de evitar danos a terceiros. ${ }^{70}$

A propriedade é assim, então, um poder dever: o proprietário tem a obrigação de explorá-la para estar em conformidade com o Direito ${ }^{71}$. Em outras palavras, a proteção ao direito de propriedade só será efetiva caso esta cumpra com a sua função social.

Entretanto, a função social não se resume à exploração econômica da propriedade. O artigo 170 da carta constitucional brasileira prevê que a ordem econômica observará os princípios da propriedade privada e da função social da propriedade e terá por fim assegurar a todos existência digna, conforme os ditames da justiça social. ${ }^{72}$

Este dispositivo constitucional reafirma o instituto da propriedade condicionada ao cumprimento de sua função social, mas relativiza, ainda mais, o seu conceito, visto que a mesma deverá observar o interesse social, de modo a não causar prejuízos para a sociedade. ${ }^{73}$

Não obstante, dispõe o artigo 182 da Constituição Federal de 1988 em seu §2 que a propriedade urbana cumpre a sua função social quando atendidas as exigências impostas pelo Plano Diretor da cidade em que se encontra localizada e este deverá, necessariamente, estabelecer instrumentos de preservação e proteção ambiental.

No mesmo sentido, prevê o artigo 186, no que tange à propriedade rural, que a sua função social é cumprida quando atendidos, simultaneamente, dentre outros, os requisitos de aproveitamento racional e adequado da propriedade, utilização adequada dos recursos naturais disponíveis e preservação do meio ambiente. ${ }^{74}$

O Código Civil de 2002 complementa tais dispositivos constitucionais em seu artigo $1228, \S 1^{\circ}$ :

"o direito de propriedade deve ser exercido em consonância com as suas finalidades econômicas e sociais e de modo que sejam preservados, de conformidade com o estabelecido em lei especial, a flora, a fauna, as belezas naturais, o equilíbrio ecológico e o patrimônio histórico e artístico, bem como evitada a poluição do ar e das águas.”

Assim como o Código Florestal de 2012 quando em seu artigo 28 proíbe a conversão de vegetação nativa para uso alternativo do solo na propriedade rural que possuir área

\footnotetext{
${ }^{70}$ GRANZIERA, Maria Luiza Machado. Direito Ambiental. $2^{a}$ ed. São Paulo: Atlas, 2011. p. 82.

${ }^{71}$ Superior Tribunal de Justiça. Agravo Regimental no Recurso Especial nº. 1138517/MG. Relator Ministro Humberto Martins. Brasília, 18 de agosto de 2011.

${ }^{72}$ Constituição Federal de 1988, artigo 170, incisos II e III.

${ }^{73}$ Constituição Federal de 1988, artigo 170, caput.

${ }^{74}$ Constituição Federal de 1988, artigo 186, incisos I e II.
} 
abandonada. ${ }^{75}$ Tal disposição faz parecer a intenção do legislador de "punir" aqueles proprietário que não utilizam parte de sua propriedade, não cumprindo com a função social da mesma.

O Código Florestal de 1965 já previa tal situação, porém com maior alcance, uma vez que incluía ainda nessa proibição as propriedades rurais com área desmatada abandonada, subutilizada ou utilizada de forma inadequada. ${ }^{76}$

Constata-se, portanto, com os dispositivos jurídicos citados acima que o legislador brasileiro atrelou a propriedade ao cumprimento de outros valores de cunho social que deverão obrigatoriamente ser respeitados, sob pena de a propriedade não ser juridicamente garantida e respeitada.

Dentre tais valores destaca-se aqui a preservação do meio ambiente, caracterizando a função socioambiental da propriedade, a qual legitima diversos institutos ambientais que restringem o exercício do direito de propriedade, como é o caso da Reserva Florestal Legal ${ }^{77}$, conforme o entendimento do Superior Tribunal de Justiça: “as Áreas de Preservação Permanente (APPs) e a Reserva Legal densificam e concretizam a função ecológica da propriedade (artigos 170, VI, 186, II e 225 da Constituição Federal) (...).”78

A Reserva Florestal Legal, como será oportunamente tratado, é, então, uma limitação administrativa imposta à propriedade que encontra fundamento neste princípio da função socioambiental da propriedade.

\subsubsection{Princípio do Desenvolvimento Sustentável}

O princípio do desenvolvimento sustentável abrange a ideia de desenvolvimento econômico levando-se em consideração a preocupação ambiental e social, que é um tema atualmente indispensável nas discussões internacionais e nacionais sobre meio ambiente, conforme nos ensina Paulo de Bessa Antunes “as principais declarações internacionais sobre meio ambiente sempre levam em consideração a necessidade de desenvolvimento econômico, que deverá ser realizado de forma sustentável."79

\footnotetext{
${ }^{75}$ Lei $n^{\circ}$. 12.651 de 25-05-2012, artigo 28.

${ }^{76}$ Lei no $.4 .771 / 1965$, artigo 37-A, caput, revogado pela Lei no ${ }^{\circ}$ 12.651/2012.

${ }^{77}$ COSTA NETO, Nicolao Dino de Castro e. Proteção Jurídica do Meio Ambiente - I Florestas.Belo Horizonte: Del Rey, 2003. p. 56.

${ }^{78}$ Superior Tribunal de Justia. Recurso Especial nº 948.921/SP. Relator Ministro Herman Benjamin. Brasília, 23 de outubro de 2007.

${ }^{79}$ ANTUNES, Paulo de Bessa. Direito Ambiental. 12a ed. Rio de Janeiro: Lumen Juris, 2010. p. 24.
} 
Nesse contexto, a Conferência de Estocolmo (1972) já previa a necessidade de conservação dos recursos naturais em prol dos interesses das gerações futuras, pois conforme preleciona Maria Luiza Machado Granziera, “a Conferência da ONU de 1972 deflagrou o alerta, pois mostrou ao mundo os efeitos do desenvolvimento e da industrialização sem um planejamento e uma cautela especial na preservação dos recursos naturais”. ${ }^{80}$

Entretanto, o conceito de desenvolvimento sustentável engendrou-se internacionalmente na Conferência do Rio de Janeiro de 1992, que teve por base o Relatório Brundtland, elaborado pela Comissão Mundial sobre Meio Ambiente e Desenvolvimento e apresentado à Organização das Nações Unidas (ONU) em $1987 .{ }^{81}$

Tal relatório afirma que desenvolvimento sustentável é desenvolvimento que "satisfaz as necessidades presentes, sem comprometer a capacidade das futuras gerações de suprir suas próprias necessidades." 82

Contata-se que esta definição tem por fulcro o princípio da solidariedade intergeracional somado à premissa de que os recursos naturais são finitos e necessários à sobrevivência da raça humana e que, portanto, não há como explorá-los indefinidamente em prol do progresso econômico.

Aqueles empreendedores que, necessariamente, utilizam recursos naturais para desenvolverem suas atividades, devem ter uma perspectiva futura, no sentido de avaliarem a disponibilidade desses recursos para que não cheguem a sua exaustão.

O mesmo ocorre em relação às florestas, que deverão ser exploradas de forma racional, "evitando-se o desflorestamento descontrolado,"83 com a adoção de medidas protecionistas, tais como a que veremos mais adiante.

Portanto, contata-se que as necessidades humanas, ao contrário dos recursos naturais, são ilimitadas e, por este motivo, as políticas econômicas, sociais e ambientais deverão ser integradas, na busca da sustentabilidade. ${ }^{84}$

\footnotetext{
${ }^{80}$ GRANZIERA, Maria Luiza Machado. Direito Ambiental. 2a ed. São Paulo: Atlas, 2011. p. 58.

${ }^{81}$ GRANZIERA, Maria Luiza Machado. Direito Ambiental. 2a ed. São Paulo: Atlas, 2011. p. 44 e 45.

${ }^{82}$ Relatório Brudtland e a sustentabilidade. Mudanças climáticas. Disponível em http://www.mudancasclimaticas.andi.org.br/node/91 Acesso em 07 de maio de 2012.

${ }^{83}$ COSTA NETO, Nicolao Dino de Castro e. Proteção Jurídica do Meio Ambiente - I Florestas. Belo Horizonte: Del Rey, 2003. p. 62.

84 AMADO, Frederico Augusto Di Trindade. Direito Ambiental Esquematizado. $2^{\mathrm{a}}$ ed. Rio de Janeiro: Forense, São Paulo: Método, 2011. p. 44.
} 
É esta a ideia contida no Princípio 04 da Conferência do Rio de Janeiro (1992): “Para alcançar o desenvolvimento sustentável, a proteção ambiental constituirá parte integrante do processo de desenvolvimento e não pode ser considerada isoladamente deste.”,85

As normas que versam sobre a tutela ambiental, então, não objetivam excluir o progresso econômico e sim adequá-lo à preservação do meio ambiente. Têm por escopo promover uma relação de harmonia do homem para com o ambiente em que vive, sem que seja necessário frear as suas atividades econômicas, sem que se prejudique a qualidade de vida da sociedade e a disponibilidade dos recursos naturais.

É o que se extrai do artigo 170, inciso VI, da Constituição Federal de 1988 ao prever que a ordem econômica tem por fim assegurar a todos existência digna, conforme os ditames da justiça social, observado, dentre outros, o princípio de defesa do meio ambiente. E, no mesmo sentido, a Lei da Política Nacional do Meio Ambiente, Lei 6.938 de 1981, em seu artigo $4^{\circ}$, inciso I, ao determinar que a política ambiental "visará à compatibilização do desenvolvimento econômico social com a preservação da qualidade do meio ambiente e do equilíbrio ecológico”.

Inclusive o Superior Tribunal Federal no julgamento sobre a regulamentação de importação de pneus usados divulgado em seu Informativo $\mathrm{n}^{\circ} .552$ decidiu proibir a prática dessa atividade econômica com fundamento na proteção ambiental prevista no artigo constitucional acima citado:

"Entendeu-se, em síntese, que, apesar da complexidade dos interesses e dos direitos envolvidos, a ponderação dos princípios constitucionais revelaria que as decisões que autorizaram a importação de pneus usados ou remoldados teriam afrontado os preceitos constitucionais da saúde e do meio ambiente ecologicamente equilibrado e, especificamente, os princípios que se expressam nos artigos 170, I e VI, e seu parágrafo único, 196 e 225, todos da CF.”86

Portanto, as atividades econômicas e, principalmente, aquelas que envolvam a utilização de recursos naturais devem obrigatoriamente compatibilizar as suas práticas com a proteção ambiental. Isto não diz respeito somente ao setor privado. Ao revés, a proteção do meio ambiente deverá constar como requisito indispensável no desenvolvimento das políticas públicas econômicas.

Entretanto, de acordo com a autora Maria Luiza Machado Granziera

\footnotetext{
${ }^{85}$ Declaração do Rio sobre Meio Ambiente e Desenvolvimento. Ministério do Meio Ambiente. Disponível em www.mma.gov.br/sitio/index.php?ido=conteudo.monta\&idEstrutura=18\&idConteudo=576. Acesso em 19 abril 2012. ${ }^{86}$ Supremo Tribunal Federal, ADPF n ${ }^{\circ}$ 101/DF, Relatora Ministra Carmen Lúcia, Brasília, 24 de junho de 2009.
} 
“esse conceito não propõe ações facilmente assimiláveis. Os conflitos existem na composição entre desenvolvimento e proteção do ambiente. O consenso e a compreensão sobre a preservação do meio ambiente para as gerações futuras é um desafio a ser incorporado nas ações humanas” ${ }^{87}$.

Para se garantir o cumprimento do princípio do desenvolvimento sustentável torna-se necessário a adoção de instrumentos que controlem e fiscalizem a prática das atividades humanas do início ao fim, no sentido de se verificar o cumprimento das normas de proteção ambiental, evitando-se, assim, a superveniência de danos que possam perdurar por tempo indefinido, pois "não basta que inicialmente se comprove a sustentabilidade de um empreendimento quando do seu licenciamento. É preciso que essa sustentabilidade perdure, ao longo de toda a atividade" ${ }^{88}$.

Assim, a legislação florestal deve ser efetiva, com previsão de instrumentos capazes de controlar a exploração das florestas ao mesmo tempo em que as preserva. A floresta é fonte essencial para determinadas atividades econômicas, mas não pode ser vista somente como um objeto de obtenção de vantagens econômicas e sim como elemento ambiental que necessita de proteção para resguardar a qualidade de vida dos seres humanos, sendo indispensável, então, a regulamentação de sua exploração.

Portanto, o conceito de desenvolvimento sustentável consiste no desenvolvimento econômico com a observância obrigatória da defesa do meio ambiente, ou seja, na exploração adequada dos recursos naturais, de modo que não comprometa de forma drástica o meio natural e, consequentemente, prejudique a sadia qualidade de vida das gerações presentes e vindouras $^{89}$.

\subsubsection{Princípio da Precaução}

A política de proteção ambiental não se limita à mitigação e reparação do dano, mas prevê instrumentos capazes de evitá-lo e combatê-lo antes mesmo de sua concretização. É com este último intuito, de obstar a ocorrência do dano que os princípios da prevenção e precaução relacionam-se.

A particularidade do bem tutelado pelas normas protecionistas ambientais justifica o caráter preventivo e precavido destas. Portanto, o ditado popular "melhor prevenir do que remediar” deverá sempre ser aplicado ao Direito Ambiental, uma vez que as agressões ao

\footnotetext{
${ }^{87}$ GRANZIERA, Maria Luiza Machado. Direito Ambiental. 2a ed. São Paulo: Atlas, 2011. p. 58.

${ }^{88}$ GRANZIERA, Maria Luiza Machado. Direito Ambiental. 2a ed. São Paulo: Atlas, 2011. p. 60.

${ }^{89}$ SILVA, José Afonso da. Direito Ambiental Constitucional. 9a ed. São Paulo: Malheiros, 2011. p. 27.
} 
meio ambiente são, normalmente, de difícil reparação ou demandam longo prazo, quando não são irreversíveis.

O Superior Tribunal de Justiça recentemente reconheceu que os princípios em questão são basilares da tutela ambiental, conforme se depreende do trecho destacado abaixo:

"Não custa pontuar que, na seara ambiental, o aspecto temporal ganha contornos de maior importância, pois, como se sabe, a potencialidade das condutas lesivas aumente com a submissão do meio ambiente aos agentes degradadores. Tanto é assim que os princípios basilares da Administração Pública são o da prevenção e da precaução, cuja base empírica é justamente a constatação de que o tempo não é um aliado, e sim um inimigo da restauração e da recuperação ambiental."90

Literalmente, os termos precaução e prevenção são sinônimos. Entretanto, a doutrina ambiental distingue-os quanto às características dos riscos que pretendem inibir, definindo que o princípio da prevenção tem por objeto os riscos concretos, visíveis, conhecidos, enquanto que o princípio da precaução os riscos abstratos e de difícil visualização. ${ }^{91}$

Assim é que a prevenção tem por objeto um risco certo e conhecido. Não há dúvidas de que determinado dano ambiental irá ocorrer. Já a precaução é permeada de incertezas sobre a sucessão do dano. O risco existe, mas a probabilidade de gerar um dano não é comprovada cientificamente. ${ }^{92}$

Por este motivo, eles serão aqui tratados separadamente como dois princípios distintos e autônomos.

Conforme o dicionário Houaiss da língua portuguesa, precaução é uma "medida antecipada que visa a prevenir um mal”, também sinônimo de prudência, cautela e cuidado. ${ }^{93}$

No âmbito do Direito Ambiental, a precaução traduz a impossibilidade de realização de determinada atividade quando não se tenha certeza dos danos que ela causará ao meio ambiente, ou ainda, se tais danos forem considerados irreversíveis. ${ }^{94}$

A afirmação de Jean-Marc Lavieille, citado por Paulo Affonso Leme Machado, resume perfeitamente o conteúdo do princípio da precaução: “O princípio da precaução

\footnotetext{
${ }^{90}$ Superior Tribunal de Justiça. Recurso Especial nº. 1116964/PI. Relator Ministro Mauro Campbell Marques. Brasília, 15 de março de 2011.

91 LEITE, José Rubens Morato. Sociedade de Risco e Estado.In: CANOTILHO, José Joaquim Gomes; LEITE, José Rubens Morato (Orgs.)Direito Constitucional Ambiental Brasileiro.4 ${ }^{\mathrm{a}}$ ed. São Paulo: Saraiva, 2011. p. 194.

92 AMADO, Frederico Augusto Di Trindade. Direito Ambiental Esquematizado. $2^{\mathrm{a}}$ ed. Rio de Janeiro: Forense; São Paulo: Método, 2011. p. 41.

93 HOUAISS, Antônio; VILLAR, Mauro de Salles. Dicionário Houaiss da Língua Portuguesa.Rio de Janeiro: Objetiva, 2001.

${ }^{94}$ GUERRA, Isabella Franco; LIMMER, Flávia C. Princípios Constitucionais Informadores do Direito Ambiental. In: PEIXINHO, Manoel Messias; GUERRA, Isabella Franco; NASCIMENTO FILHO; Firly. Os Princípios da Constituição de 1988.2 ${ }^{\mathrm{a}}$ ed. Rio de Janeiro: Lumen Juris, 2006. p. 659.
} 
consiste em dizer que não somente somos responsáveis sobre o que nós sabemos, sobre o que nós deveríamos saber, mas, também, sobre o de que nós deveríamos duvidar”. 95

Em âmbito nacional, apesar de implicitamente previsto na Constituição Federal de 1988, o princípio da precaução concretiza-se em suas disposições relativas à avaliação dos impactos ambientais dos empreendimentos, mediante a realização do Estudo Prévio de Impacto Ambiental ${ }^{96}$, e é prenunciado, também, em legislações complementares ${ }^{97}$ e resoluções do CONAMA (Conselho Nacional do Meio Ambiente), órgão integrante do Sistema Nacional de Meio Ambiente, regulado pela lei 6.938/1991.

Já no âmbito internacional, a Conferência do Rio de Janeiro (1992) consagrou-o em seu princípio 15, que assim prevê:

"De modo a proteger o meio ambiente, o princípio da precaução deve ser amplamente observado pelos Estados, de acordo com suas capacidades. Quando houver ameaça de danos sérios ou irreversíveis, a ausência de absoluta certeza científica não deve ser utilizada como razão para postergar medidas eficazes e economicamente viáveis para precaver a degradação ambiental”. ${ }^{98} 99$

Desta conferência resultou a Convenção sobre Mudança do Clima e a Convenção da Biodiversidade, que também preveem expressamente tal princípio, sendo o Brasil parte signatária em ambas.

O Ministro Carlos Britto em seu voto proferido nos autos do Agravo Regimental interposto na Ação Cível Originária n876, que teve por objeto a transposição do Rio São Francisco, reconhece a importância do princípio da precaução:

"Ressalto que esse artigo 225 é de núcleo semântico plurissignificativo, dos mais importantes da Constituição brasileira, pelos bens jurídicos tutelados num só dispositivo. Aí, a Constituição faz das futuras gerações uma preocupação, cuidando de interesses de quem não existe ainda - interessante isso. As futuras gerações já estão sendo objeto de proteção constitucional por via do artigo 225.

A partir desse artigo é que surgem vários princípios de caráter ambiental, como o princípio da precaução e o da prevenção, que embora coloquialmente sejam palavras sinônimas, sejam coisas iguais, tecnicamente não: um, objetiva evitar riscos ao meio ambiente, com todas as medidas necessárias de prevenção; outro, que é o da precaução, traduz-se no seguinte: em caso de dúvida, se há ou se não há lesão ao meio ambiente, não se faz a obra. Estanca-se ou paralisa-se a atividade.”100

\footnotetext{
95 Apud. MACHADO, Paulo Affonso Leme. Direito Ambiental Brasileiro. 14 a ed. São Paulo: Malheiros, 2006. p. 72.

${ }^{96}$ Constituição Federal de 1988, artigo 225, §1º, inciso IV.

${ }^{97}$ A exemplo da Lei 9.605/98, artigo 54, §3 .

${ }^{98}$ Declaração do Rio sobre Meio Ambiente e Desenvolvimento. Ministério do Meio Ambiente. Disponível em www.mma.gov.br/sitio/index.php?ido=conteudo.monta\&idEstrutura=18\&idConteudo=576. Acesso em 19 abril 2012.

${ }^{99}$ Apesar desta Declaração não ter natureza jurídica de tratado internacional, o que faz com que não vincule juridicamente os seus signatários, é considerada uma convenção ética e moral reconhecida mundialmente, com grande importância em âmbito ambiental internacional.

${ }^{100}$ Supremo Tribunal Federal, ACO nº 876 MC-Agr/BA, Ministro Menezes Direito, Bahia, 19.12.2007.
} 
Cumpre ressaltar que o princípio da precaução não tem por escopo inviabilizar o desenvolvimento econômico. ${ }^{101}$ Ao contrário, ele visa alertar os empreendedores, no planejamento de seus empreendimentos, e os órgãos ambientais, no licenciamento de tais atividades, sobre a necessidade da adoção de medidas capazes de auxiliar a tomada de decisões em casos onde não se conheça plenamente os danos ambientais. ${ }^{102}$

Pretende-se demonstrar que determinada atividade só poderá se concretizar caso existam conhecimentos consideráveis sobre os seus efeitos no meio ambiente e suficientes à orientação na adoção de medidas que evitem a degradação ambiental. Caso contrário, ou seja, quando não existir a certeza de que aquela atividade não causará danos irreversíveis ao meio ambiente, o seu licenciamento não deverá ocorrer ${ }^{103}$, ou seja, “a incerteza científica quanto a lesividade atua em prol do meio ambiente (in dubio pro ambiente).”104

É nesse aspecto que o princípio da precaução relaciona-se com o princípio do desenvolvimento sustentável, uma vez que os empreendedores ao desenvolverem atividades que de algum modo envolvem o meio ambiente deverão certificar-se de que o mesmo será protegido e para tanto analisa-se previamente os riscos dos impactos.

\subsubsection{Princípio da prevenção}

O princípio da prevenção trabalha com riscos já identificados, de natureza e extensão conhecidas cientificamente e "versa sobre a busca da compatibilização entre a atividade a ser licenciada e a proteção ambiental, mediante a imposição de condicionantes ao projeto”. 105

Tal como o princípio da precaução, este princípio concretiza-se também na disposição constitucional relativa ao Estudo Prévio de Impacto Ambiental, no âmbito do processo de Licenciamento Ambiental, exigido para aqueles empreendimentos que sejam lesivos ao meio ambiente, ainda que potencialmente. ${ }^{106}$

Então, o Estudo de Impacto Ambiental e o Licenciamento Ambiental são instrumentos da Política Nacional do Meio Ambiente que materializam o princípio da prevenção e, realizados anteriormente à instalação do empreendimento, são capazes de prever os aspectos

\footnotetext{
${ }^{101}$ GRANZIERA, Maria Luiza Machado. Direito Ambiental. 2a ed. São Paulo: Atlas, 2011. p. 63.

${ }^{102}$ MACHADO, Paulo Affonso Leme. Direito Ambiental Brasileiro. 14 a ed. São Paulo: Malheiros, 2006. p. 65.

${ }^{103}$ GRANZIERA, Maria Luiza Machado. Direito Ambiental. 2a ed. São Paulo: Atlas, 2011. p. 62.

${ }^{104}$ COSTA NETO, Nicolao Dino de Castro e. Proteção Jurídica do Meio Ambiente - I Florestas. Belo Horizonte: Del Rey, 2003. p. 70.

${ }^{105}$ GRANZIERA, Maria Luiza Machado. Direito Ambiental. $2^{\mathrm{a}}$ ed. São Paulo: Atlas, 2011. p. 60.

${ }^{106}$ Constituição Federal de 1988, artigo 225, §1 ${ }^{\circ}$, inciso IV.
} 
ambientais negativos, evitando-os, mitigando-os ou minimizando-os, sem que com isso seja necessário inviabilizar a concretização de determinada atividade econômica.

Conforme já mencionado, é certo que remediar para o Direito Ambiental muitas vezes não é suficiente, tendo em vista que a degradação ambiental, geralmente, tem natureza irreversível. E quando não irreversíveis, os danos ambientais são de difícil reparação, levando-se anos ou séculos para que aquele meio afetado seja recomposto.

Por isso é que, conforme disposição constitucional, o Estudo de Impacto Ambiental deverá ser elaborado previamente a realização da atividade, a fim de que impeça a superveniência de degradação ambiental.

É essa a ideia da prevenção em âmbito ambiental: o homem não deve atuar sobre o meio ambiente sem a prévia avaliação das consequências dessa atuação. Ao revés, ele deve atuar com vistas a evitar a concretização de danos que podem ser irreversíveis. Já que se possui noção dos impactos que aquela atividade irá causar ao meio ambiente, deve-se, então, fazer o possível para minimizá-los.

Assim, afirma Maria Luiz Machado Granziera que

"havendo uma análise prévia dos impactos que um determinado empreendimento possa causar ao meio ambiente é possível adotando-se medidas compensatórias e mitigadoras, e mesmo alterando-se o projeto em análise, se for o caso, assegurar a sua realização, garantindo-se os benefícios econômicos dele decorrentes, sem causar danos ao meio ambiente" ${ }^{107}$.

Portanto, para o Direito Ambiental prevenir é adotar medidas capazes de evitar a concretização de determinado dano anteriormente ao planejamento do empreendimento que com ele possui relação de causalidade. A prevenção tem um papel importantíssimo para a tutela ambiental. Com conhecimentos científicos suficientes para prever os danos oriundos de uma atividade, deve-se impor ao empreendedor obrigações apropriadas para impedir a deterioração do meio ambiente.

\subsubsection{Princípio do Equilíbrio}

Este princípio impõe aos aplicadores do Direito Ambiental uma análise profunda das consequências que a implantação de determinada atividade irá gerar em âmbito ambiental, social, político, econômico, etc.

${ }^{107}$ GRANZIERA, Maria Luiza Machado. Direito Ambiental. 2a ed. São Paulo: Atlas, 2011. p. 61. 
A exploração do meio ambiente deve ser útil a toda a comunidade nacional e até mesmo global, sem que comprometa excessivamente a capacidade de renovação dos recursos naturais e à qualidade de vida do ser humano.

Conforme os ensinamentos de Paulo de Bessa Antunes "princípio do equilíbrio é o princípio pelo qual devem ser pesadas todas as implicações de uma intervenção no meio ambiente, buscando-se adotar a solução que melhor concilie um resultado globalmente positivo" ${ }^{108}$.

${ }^{108}$ ANTUNES, Paulo de Bessa. Direito Ambiental. 12ª ed. Rio de Janeiro: Lumen Juris, 2010. p. 46. 


\section{A Reserva Florestal Legal}

\subsection{Previsão Legal}

O primeiro Código Florestal brasileiro foi promulgado no ano de 1934, durante o governo de Getúlio Vargas, baixado pelo Decreto 23.793 de 23 de janeiro de 1934, dispondo em seu artigo $1^{0}$ que as florestas eram bens de interesse comum do povo, bem como classificando-as conforme sua finalidade em protetoras, remanescentes, modelo e de rendimento. Previa, ainda, a instituição de áreas de proteção, denominadas à época de florestas protetoras. 109

Em uma leitura geral de seus dispositivos, percebe-se que a preocupação primordial do legislador era regulamentar a exploração econômica das florestas e não essencialmente em conservar e preservar as suas características físicas e bióticas.

No entanto, pode-se afirmar que a ideia da Reserva Florestal legal foi introduzida no ordenamento jurídico brasileiro com o Código Florestal de 1934, embora não possuísse, àquela época, os contornos tais como possui atualmente, bem como sem uma denominação formal, mas permeada do mesmo fundamento de se preservar parte da cobertura vegetal da propriedade.

É o que se observa com a leitura de seu artigo 23: "nenhum proprietário de terras cobertas de mattas poderá abater mais de três quartas partes da vegetação existente”, ${ }^{110}$ com algumas exceções por ele estabelecidas.

Ainda assim, o Código Florestal de 1934 tornou-se ineficaz, pois, conforme nos ensina José Afonso da Silva, “suas normas não tiveram aplicação rigorosa que impedisse a contínua devastação de nossas florestas e outras formas de vegetação”. 111

E, por este motivo, foi substituído pelo Código Florestal de 1965, instituído pela Lei $\mathrm{n}^{\circ}$. 4.471 de 15 de setembro de 1965, o qual foi significativamente alterado pela Medida Provisória nº 2.166-67 de 2001.

Os avanços obtidos pela legislação de 1934 não só foram mantidos e aperfeiçoados no Código Florestal de 1965, como a instituição de um regime jurídico específico para as áreas de Reserva Florestal Legal, como também ocorreram inovações primordiais para a efetiva

\footnotetext{
109 Decreto $\mathrm{n}^{\mathrm{o}}$. 23.793 de 23 de janeiro de 1934, artigo $1^{\circ}$. Disponível em <http://www.planalto.gov.br/ccvil_03/decreto/1930-1949/d23793.htm>

${ }^{110}$ Decreto $n^{\circ} .23 .793$ de 23 de janeiro de 1934, artigo 23, caput. Disponível em <http://www.planalto.gov.br/ccvil_03/decreto/1930-1949/d23793.htm>

${ }^{111}$ SILVA, José Afonso da. Direito Ambiental Constitucional. 9a ed. São Paulo: Malheiros, 2011. p. 174.
} 
proteção e conservação das florestas, como por exemplo, a criação dos espaços de preservação permanente.

Mesmo com a previsão de normas eficazes para a conservação e preservação da flora brasileira, o Código Florestal de 1965 há muito é alvo de críticas oriundas principalmente do setor agrícola no que se refere, especialmente, às áreas de proteção citadas acima, que por serem instrumentos que atingem o direito de propriedade, mais especificamente a propriedade rural, inviabilizariam o desenvolvimento econômico do Brasil.

Tais críticas ensejaram a tramitação de diversos projetos de lei perante o Congresso Nacional com o objetivo de reformular a lei de proteção florestal e, consequentemente, desconstituir os avanços alcançados em matéria de conservação florestal, aumentando, assim, a área rural produtiva do país.

O debate em torno do Código Florestal retornou à pauta de discussão no cenário político com a tramitação do Projeto de Lei 1.876 de 1999, que se caracterizou erroneamente como uma disputa entre o setor ruralista e o setor ambientalista. Erroneamente porque a questão ambiental é multidisciplinar, envolvendo diversos outros setor da sociedade, muito além dos que verdadeiramente foram envolvidos na discussão sobre tal projeto de lei,

Foi nesse contexto, sem a realização de um debate amplo que levasse em consideração a complexidade e especificidade do bem ambiental, que o Projeto de Lei ${ }^{\circ}$. 1.876 de 1999 foi aprovado em ambas as casas do Congresso Nacional e sancionado pela Presidente da República, Dilma Roussef às vésperas da realização da Conferência das Nações Unidas sobre Desenvolvimento Sustentável, que será realizada no Rio de Janeiro, em junho do presente ano.

Ainda que tenha ela apresentado alguns vetos ao projeto, os quais serão analisados pelo Congresso Nacional, o projeto de lei foi transformado na lei ordinária $n^{\circ}$. 12.651 de 25 de maio de 2012, a qual revogou o Código Florestal de 1965 instituindo, então, um novo Código Florestal, atualmente em vigor, o qual estabelece o regime jurídico do instituto da Reserva Florestal Legal que será aqui minuciosamente delineado, uma vez que os mencionados vetos não interferem diretamente neste instituto.

Além dos vetos, a Presidente da República adotou a Medida Provisória nº 571 de 25 de maio de 2012 para alterar a mencionada Lei $n^{\circ}$. 12.651/2012, incluindo, assim, diversos dispositivos antes não previstos no texto aprovado pelos deputados e senadores federais. 
Dentre as modificações incluídas pela MP acima citada, destaca-se a inserção do artigo $1^{\mathrm{o}}$-A no texto original aprovado pelo Congresso Nacional. Esse dispositivo transparece a prioridade o compromisso nacional com o desenvolvimento sustentável ao prever que a Lei $n^{\circ}$. 12.651/2012 tem como fundamento central a proteção e o uso sustentável das florestas e demais formas de vegetação em harmonia com a promoção do desenvolvimento econômico com a observância de alguns princípios, tais como:

"II- afirmação do compromisso soberano do Brasil com a preservação de suas florestas e demais formas de vegetação nativa, da biodiversidade, do solo e dos recursos hídricos, e com a integridade do sistema climático, para o bem-estar das gerações presentes e futuras;

(...)

IV- consagração do compromisso do País com o modelo de desenvolvimento ecologicamente sustentável que concilie o uso produtivo da terra e a contribuição de serviços coletivos das florestas e demais formas de vegetação nativa privadas;

V- ação governamental de proteção e uso sustentável das florestas (...);

VII - fomento à inovação para o uso sustentável, a recuperação e a preservação das florestas e demais formas de vegetação nativa; e

VIII - criação e mobilização de incentivos jurídicos e econômicos para fomentar a preservação e a recuperação da vegetação nativa, e para promover o desenvolvimento de atividades produtivas sustentáveis.” 112

Entretanto, como serão adiante analisadas, as alterações introduzidas por essa lei regridem em alguns aspectos quanto à proteção e preservação das florestas, deixando transparecer a intenção do legislador também em privilegiar a produção rural brasileira.

Ressalta-se que o Código Florestal traz normas gerais de aplicabilidade em todo território nacional que tem por objeto não só as florestas, mas todas as formas de vegetação, desde que consideradas úteis ao solo que revestem, sendo esta a única condição necessária para o ensejo de sua proteção, o que revela que as terras propriamente ditas também estão enquadradas no rol dos bens jurídicos tutelados pela lei florestal. ${ }^{113}$

Assim prevê o seu artigo $2^{\circ}$ :

"As florestas existentes no território nacional e as demais formas de vegetação, reconhecidas de utilidade às terras que revestem, são bens de interesse comum a todos os habitantes do País, exercendo-se os direitos de propriedade, com as limitações que a legislação em geral e especialmente este Lei estabelecem.

$\S 1^{\circ}$ - Na utilização e exploração da vegetação, as ações ou omissões contrárias às disposições desta Lei são consideradas uso irregular da propriedade, aplicando-se, para o caso, o procedimento sumário previsto no inciso II do artigo 275 da Lei no .5 .869 de 11 de janeiro de 1973-Código de Processo Civil, sem prejuízo da responsabilidade civil, nos termos do $\S 1^{\circ}$ do artigo 14 da Lei $n^{\circ} .6 .938$ de 31 de agosto de 1981, e das sanções administrativas, civis e penais."

\footnotetext{
112 Lei no. 12.651 de 25 de maio de 2012, artigo 1-A, caput e incisos II, IV e V.

${ }^{113}$ ANTUNES, Paulo de Bessa. Direito Ambiental. 12 a ed. Rio de Janeiro: Lumen Juris, 2011. p. 511.

${ }^{114}$ Lei $n^{\circ}$. 12.651 de 25 de maio de 2012, artigo $2^{\circ}$, caput e $\$ 1^{\circ}$.
} 
Tal previsão é reprodução do artigo $1^{\circ}$ do Código Florestal de 1965, exceto no que diz respeito à caracterização das ações e omissões contrárias a legislação florestal, que no antigo código eram consideradas como uso nocivo da propriedade, sendo atualmente consideradas como uso irregular da propriedade, parecendo não existir significativas diferenças entre um termo e outro.

A caracterização das florestas como bens de interesse comum traduz a relevância desses ecossistemas para a humanidade, que, por esse motivo, submete-se a um regime jurídico especial. São, portanto, consideradas bens de interesse público, ainda que estejam sob o domínio privado. ${ }^{115}$

A identidade do proprietário de uma floresta não modificará o dever legal de protegêla e conservá-la. Conforme nos ensina Maria Luiza Machado Granziera:

"o exercício do direito de propriedade, à luz do Código Florestal, ficou condicionado às limitações que a legislação estabelece e que se referem a todas as regras e restrições à supressão de vegetação, seja nas Áreas de Preservação Permanente e Reserva Legal, e a outros regimes de proteção (....)."116

Além disso, considera-se uso irregular da propriedade as ações ou omissões relacionadas à utilização e exploração das florestas que sejam contrárias a disposições do Código Florestal. Como a redação do Código Florestal de 1965 referia-se ao uso nocivo da propriedade, os doutrinadores ambientais definem-no como sendo aquele uso que deteriora, prejudica e causa danos, ou seja, é a utilização da propriedade em desconformidade com a sua função social e ambiental. ${ }^{117}$

Entende-se que a expressão uso irregular também pretende significar aquele uso incompatível com o cumprimento da função social da propriedade.

O sistema normativo adotado pelo atual Código Florestal visa estimular a produção rural ao mesmo tempo em que visa racionalizar o uso das florestas com a previsão de diversos instrumentos, alguns de cunho econômico, necessários à conservação ambiental, que em comparação à legislação florestal de 1965 foram flexibilizados em prol do desenvolvimento econômico do país.

Dentre tais instrumentos, destacam-se como mais relevantes do ponto de vista protecionista os espaços de preservação permanente definidos pelo inciso II do artigo $3^{\circ}$ e regulados pelo artigo $4^{\circ}$ e seguintes, e as áreas de Reserva Florestal Legal, objeto principal do

\footnotetext{
${ }^{115}$ SILVA, José Afonso da. Direito Ambiental Constitucional. 9a ed. São Paulo: Malheiros, 2011. p. 176.

${ }^{116}$ GRANZIERA, Maria Luiza Machado. Direito Ambiental. $2^{\text {a }}$ ed. São Paulo: Atlas, 2011. p. 225.

${ }^{117}$ MACHADO, Paulo Affonso Leme. Direito Ambiental Brasileiro. 14 ed. São Paulo: Malheiros, 2066. p. 720.
} 
presente trabalho, as quais são conceituadas pelo inciso III do artigo $3^{\circ}$ e regulamentadas pelo artigo 12 e seguintes.

Cumpre destacar aqui que o Código Florestal utiliza a nomenclatura “reserva legal”. Entretanto, conforme a doutrina ambiental, o termo Reserva Florestal Legal torna-se mais adequado, pois é instituto jurídico diretamente relacionado à proteção florestal e conforme explica Edis Milaré evita-se com este termo confusões com o princípio da reserva legal previsto constitucionalmente, o qual determina que "ninguém será obrigado a fazer ou deixar de fazer alguma coisa senão em virtude de lei." termo Reserva Florestal Legal, exceto quando ocorrerem menções expressas aos dispositivos legais florestais.

\subsection{Conceito}

Como um dos instrumentos de efetivação do direito ao meio ambiente ecologicamente equilibrado, o instituto da Reserva Florestal Legal determina que uma parcela das florestas que se encontram sob os contornos de propriedades rurais deverá ser retirada da atividade econômica e só poderá ser submetida a determinados regimes de exploração. ${ }^{119}$

O Código Florestal traz a definição do instituto da Reserva Florestal como sendo

"a área localizada no interior de uma propriedade ou posse rural, delimitada nos termos do art. 12 com a função de assegurar o uso econômico de modo sustentável dos recursos naturais do imóvel rural, auxiliar a conservação e a reabilitação dos processos ecológicos e promover a conservação da biodiversidade, bem como o abrigo e a proteção da fauna silvestre e da flora nativa." ${ }^{, 120}$

Percebe-se que a principal preocupação do legislador ao criar este instituto foi preservar e conservar o meio ambiente, especialmente a cobertura vegetal, conservando, consequentemente, a biodiversidade brasileira. Reduz, com isso, a possibilidade de desmatamento de novas áreas ao mesmo tempo em que incentiva a sua utilização de forma sustentável.

Entretanto, o legislador optou por incluir como uma das funções da Reserva Florestal Legal o uso econômico dos recursos naturais. Na verdade, a prioridade dessas áreas não deveria ser promover benefícios econômicos, mas sim, conforme dito acima, preservar e conservar a flora brasileira.

\footnotetext{
${ }^{118}$ Constituição Federal, artigo 5ㅜ inciso II.

${ }^{119}$ ANTUNES, Paulo de Bessa. Direito Ambiental. 12 a ed. Rio de Janeiro: Lumen Juris, 2011. p. 540.

${ }^{120}$ Lei $n^{\circ} .12 .651$ de 25 de maio de 2012, artigo $3^{\circ}$, inciso III.
} 
De qualquer modo, o uso econômico deverá ser realizado de modo sustentável, o que concretiza o princípio do desenvolvimento sustentável, bem como a imposição constitucional de se preservar e conservar o meio ambiente para as gerações presentes e futuras. Nesse sentido, discorre Paulo Affonso Leme Machado: "usa-se menos a propriedade, para usar-se sempre. A existência de uma Reserva Florestal, mas do que uma imposição legal, é um ato de amor a si e a seus descendentes.” 121

Extrai-se ainda do dispositivo normativo citado acima que a incidência da área de Reserva Florestal Legal se dá somente em propriedades rurais, não importando se são de domínio público ou privado.

Sobre este último ponto, não existia na legislação florestal de 1965 considerações explícitas. No entanto, comparando-se a redação original do artigo 16 do Código Florestal de 1965, que regulava o instituto da Reserva Florestal Legal, com aquela introduzida pela Medida Provisória nº 2.166-67 de 2001, era possível a interpretação de que a área de proteção recairia tanto sobre as propriedades rurais privadas quanto sobre as públicas.

Isto porque a redação original do caput do artigo 16 estabelecia que as florestas de domínio privado seriam suscetíveis de exploração desde que observados os limites de preservação, ou seja, desde que cumpridos os percentuais de área de Reserva Florestal Legal. Não fazia menção, portanto, às propriedades rurais públicas, criando, com isso, uma ressalva quanto à incidência do instituto.

Tal redação foi revogada e consequentemente a ressalva que trazia em si, sendo substituída por nova escrita do artigo em comento, que não mencionava a titularidade das propriedades rurais sob as quais recairia a restrição protecionista, concluindo-se, enfim, que a exceção legal quanto à incidência de Reserva Florestal Legal em propriedades rurais públicas não mais prospera no sistema normativo do Código Florestal.

Entretanto, com a promulgação da Lei $\mathrm{n}^{\circ}$. 12.651/2012 não restam mais dúvidas quanto à titularidade da propriedade rural na qual incidirá a obrigação do cumprimento de manter áreas de Reserva Florestal Legal, uma vez que seu artigo 17, caput, estabelece explicitamente que parte da cobertura de vegetação nativa dos imóveis rurais deverá ser conservada pelo proprietário do imóvel rural, possuidor ou ocupante a qualquer título, pessoas físicas ou jurídicas, de direito público ou privado. ${ }^{122}$

\footnotetext{
${ }^{121}$ MACHADO, Paulo Affonso Leme. Direito Ambiental Brasileiro. 14 ${ }^{\mathrm{a}}$ ed. São Paulo: Malheiros, 2006. p. 741.

${ }^{122}$ Lei $n^{\circ} .12 .651$ de 25 de maio de 2012, artigo 17, caput.
} 
A Reserva Florestal Legal é uma obrigação geral decorrente diretamente de lei e que, como tal, não gera para o seu proprietário o direito à indenização, caracterizando-se, conforme o entendimento do Superior Tribunal de Justiça, como limitação administrativa à propriedade:

“Em nosso sistema normativo (Código Florestal - Lei. 4771/65, artigo 16 e parágrafos; Lei 8.171/91, artigo 99), a obrigação de demarcar, averbar e restaurar a área de reserva legal nas propriedades rurais constitui (a) limitação administrativa ao uso da propriedade privada destinada a tutelar o meio ambiente, que deve ser defendido e preservado para as presentes e futuras gerações ( $\mathrm{CF}$, artigo 225)."

Cumpre observar que no julgado citado acima o Superior Tribunal de Justiça faz menção à averbação da Reserva Florestal Legal, exigência do antigo Código Florestal de 1965 que não foi preservada pela lei nº. 12.651/2012, conforme será oportunamente tratado.

Não obstante, Paulo de Bessa Antunes entende que a Reserva Florestal Legal não consiste propriamente em uma limitação à propriedade e sim em um elemento essencial à caracterização legal das propriedades florestais e aquelas que não possuírem tal elemento são juridicamente inexistentes. ${ }^{124}$

Na verdade, conforme já exposto, o elemento essencial para o reconhecimento legal da propriedade é, conforme os ditames constitucionais, o cumprimento de sua função social, princípio hoje ampliado para abranger a proteção do meio ambiente, caracterizando, assim, o princípio da função socioambiental das propriedades. A Reserva Florestal Legal não se confunde com este principio e é nele que encontra seu maior respaldo. Então, constitui-se uma limitação administrativa à propriedade, que tem por fundamento um dos elementos essenciais à caracterização desta, qual seja o cumprimento de sua função socioambiental.

De qualquer forma, a Reserva Florestal Legal concretiza a determinação do Código Florestal de que as florestas são bens de interesse comum de todos os habitantes do País, ${ }^{125}$ sendo, ainda, um importante instrumento de efetivação do direito ao meio ambiente ecologicamente equilibrado, previsto constitucionalmente, na medida em que tutela não só as florestas como também o solo, ar, fauna e demais elementos ambientais.

Além disso, a Reserva Florestal Legal consiste em um dos espaços especialmente protegidos já analisados, que deverão ser definidos pelo Poder Público com o escopo de

\footnotetext{
${ }^{123}$ Superior Tribunal de Justiça. Recurso Especial no . 1.179.316/SP, Relator Ministro Teoria Albino Zavascki, Brasília, 15 de junho de 2010.

${ }^{124}$ ANTUNES, Paulo de Bessa. Direito Ambiental. $12^{\text {a }}$ ed. Rio de Janeiro: Lumen Juris, 2011. p. 536 e 537.

${ }^{125}$ ANTUNES, Paulo de Bessa. Direito Ambiental. 12 ${ }^{\mathrm{a}}$ ed. Rio de Janeiro: Lumen Juris, 2011. p. 541.
} 
promover um meio ambiente equilibrado, nos termos do artigo 225 , $\S 1^{\circ}$, inciso III, da Constituição Federal de 1988.

Por fim, cabe ressaltar aqui que a Reserva Florestal Legal poderá ser instituída mediante o regime de condomínio ou coletivamente entre propriedades rurais, respeitado, é claro, os percentuais previstos para cada imóvel, os quais serão descritos adiante. ${ }^{126}$

O condomínio é um instituto regido pelo Código Civil de $2002^{127}$ e seu artigo 1.314 , caput, prevê que "cada condômino pode usar da coisa conforme sua destinação, sobre ela exercer todos os direitos compatíveis com a indivisão (...).”

Percebe-se que cada proprietário poderá utilizar a área destinada à Reserva Florestal Legal. Mas, ainda que instituída sobre esse regime, cada imóvel deverá respeitar o percentual que a lei determina e a sua instituição dependerá de aprovação do órgão ambiental estadual, bem como a averbação deverá ser realizada em relação a todos os imóveis envolvidos.

\subsection{Percentuais de Reserva Florestal Legal}

A sistemática da imposição da Reserva Florestal Legal que era prevista no Código Florestal de 1965 foi instituída pela Medida Provisória nº 2.166-67/01, alterando-o e estabelecendo os percentuais mínimos das propriedades florestais que deveriam ser mantidos a título de Reserva Florestal Legal e destinados à tutela do meio ambiente, sendo variáveis conforme a região em que a propriedade estaria inserida e a natureza de sua vegetação.

A Lei $n^{\circ}$. 12.651/2012 manteve os percentuais originários estabelecidos no Código de 1965, modificando apenas a literalidade do artigo que os previam.

Assim sendo, os percentuais mínimos atuais para as diversas regiões brasileiras destinados à preservação e manutenção das florestas e demais formas de vegetação são os seguintes:

“I -localizado na Amazônia Legal:

a) $80 \%$ (oitenta por cento), no imóvel situado em área de florestas;

b) $35 \%$ (trinta e cinco por cento), no imóvel situado em área de cerrado;

c) $20 \%$ (vinte por cento), no imóvel situado em área de campos gerais;

II - localizado nas demais regiões do País: 20\% (vinte por cento)."

O termo Amazônia Legal, utilizado no item I acima descrito, é mais um conceito político do que propriamente geográfico, que visa facilitar as ações governamentais voltadas

\footnotetext{
${ }^{126}$ Lei $\mathrm{n}^{\circ} .12 .651$ de 25-05-2012, artigo 16, caput.

${ }^{127}$ Lei $n^{\circ} .10 .406$ de 10-01-2002, artigos 1.314 a 1.358.

${ }^{128}$ Lei $\mathrm{n}^{\mathrm{o}}$. 12.651 de 25-05-2012, artigo 12, incisos I e II.
} 
ao planejamento e desenvolvimento dessa região ${ }^{129}$. O Código Florestal de 2012 traz a definição deste conceito em seu artigo $3^{\circ}$, inciso I como sendo uma área que engloba alguns estados brasileiros pertencentes à bacia amazônica, tal como previa o Código Florestal de 1965. $^{130}$

A imposição do percentual de 80\% (oitenta por cento) e 35\% (trinta e cinco por cento) para áreas de floresta e cerrado, respectivamente, localizados nessa região denominada de Amazônia Legal é originária, conforme já mencionado, da Medida Provisória $n^{\circ}$. 2.166-67, que foi editada com base nas altas taxas de desmatamento verificadas pelo Instituto Nacional de Pesquisas Espaciais (INPE). Portanto, tais percentuais tiveram o objetivo precípuo de frear o desmatamento na região amazônica.

Entretanto, o percentual de Reserva Florestal Legal exigido para essa região denominada Amazônia Legal poderá ser reduzido pelo Poder Público, para fins de recomposição, para até $50 \%$ da propriedade, naqueles municípios que possuírem mais da metade de sua área ocupada por unidades de conservação da natureza de domínio público e por terras indígenas homologadas. ${ }^{131}$

Da mesma forma, o Poder Público estadual também poderá realizar tal redução com a oitiva do Conselho Estadual de Meio Ambiente quando o Estado tiver Zoneamento Ecológico-Econômico aprovado e mais de 65\% (sessenta e cinco por cento) do seu território ocupado por unidades de conservação da natureza de domínio público, devidamente regularizadas, e por terras indígenas homologadas. ${ }^{132}$

O percentual de Reserva Florestal Legal das áreas florestais localizadas na Amazônia Legal poderá ser reduzido, ainda, pelo Poder Público federal, quando assim for indicado pelo Zoneamento Ecológico-Econômico estadual, nos imóveis com área rural consolidada, para fins de regularização, mediante recomposição, regeneração ou compensação dessas áreas, excluídas as áreas prioritárias para conservação da biodiversidade e dos recursos hídricos. ${ }^{133}$

Imóveis com área rural consolidada é um conceito novo, introduzido pela Lei $n^{\circ}$. 12.651/2012, visto que o Código Florestal de 1965 não trazia tal conceito, e é definido como

\footnotetext{
${ }^{129}$ Amazônia Legal. Disponível em <http://pt.wikipedia.org/wiki/Amazônia_Legal>. Acessado em 25 de maio de 2012. 130 Lei n⿳. 12.651 de 25-05-2012, artigo 3º inciso I: “Amazônia Legal: os Estados do Acre, Pará, Amazonas, Roraima, Rondônia, Amapá e Mato Grosso e as regiões situadas ao norte do paralelo $13^{\circ} \mathrm{S}$, dos Estados de Tocantis e Góias, e ao oeste do meridiano de $44^{\circ} \mathrm{W}$, do Estado do Maranhão.

${ }^{131}$ Lei $\mathrm{n}^{\circ}$. 12.651 de 25-05-2012, artigo $12, \S 4^{\circ}$.

${ }^{132}$ Lei $n^{\circ} .12 .651$ de 25-05-2012, artigo $12, \S 5^{\circ}$.

${ }^{133}$ Lei $^{\mathrm{o}}$. 12.651 de 25-05-2012, artigo 13, inciso I.
} 
“área de imóvel rural com ocupação antrópica preexistente a 22 de julho de 2008, com edificações, benfeitorias ou atividades agrossilvipastoris, admitida, neste último caso, a adoção do regime de pousio.” ${ }^{134}$ A data de 22 de julho de 2008 foi estabelecida como marco temporal por ser a data de publicação do Decreto $n^{\circ}$. 6.514/2008, que regulamentou as infrações e sanções administrativas como meio ambiente. Assim, tal lei estabelece ainda que as atividades em áreas de Reserva Florestal Legal desmatadas irregularmente após essa data deverão, obrigatoriamente, ser suspensas, ${ }^{135}$ devendo-se iniciar, ainda, o processo de sua recomposição em até dois anos contados da publicação da lei. ${ }^{136}$

Além de tais possibilidades de redução do percentual de reserva na região amazônica, há a previsão de que tal percentual poderá também ser majorado. Nesse sentido, estabelece o artigo 13, inciso II que quando indicado pelo Zoneamento Ecológico Econômico estadual o Poder Público federal poderá ampliar as áreas de Reserva Florestal legal em até 50\% (cinquenta por cento) dos percentuais inicialmente exigidos pela lei com o fim de cumprir metas nacionais de proteção à biodiversidade ou de redução de emissão de gases de efeito estufa.

O Zoneamento Ecológico-Econômico é um instrumento de ordenação do uso e ocupação do solo, o qual será mais adiante estudado, e aqueles Estados que não o possuem poderão elaborá-los dentro do prazo de 5 (cinco) anos contados a partir da publicação da Lei $\mathrm{n}^{\mathrm{o}}$. 12.651/2012, ou seja, até, aproximadamente, 28 de maio de $2017 .^{137}$

Cumpre ressaltar que, com as modificações introduzidas pela lei em comento, o cômputo das Áreas de Preservação Permanente no cálculo do percentual da Reserva Florestal Legal do imóvel passou a ser admitido pelo artigo 15, desde que cumpridos os seguintes requisitos:

"I - o benefício previsto neste artigo não implique a conversão de novas áreas para o uso alternativo do solo;

II - a área a ser computada esteja conservada ou em processo de recuperação, conforme comprovação do proprietário ao órgão estadual integrante do Sisnama; e

III - o proprietário ou possuidor tenha requerido inclusão do imóvel no Cadastro Ambiental Rural CAR, nos termos desta lei." ${ }^{\text {138 }}$

\footnotetext{
${ }^{134}$ Lei no .12 .651 de 25-05-2012, artigo 17, §3º, com redação dada pela Medida Provisória no .571 de 2012.

${ }^{135}$ Lei $n^{\circ}$. 12.651 de 25-05-2012, artigo $3^{\circ}$, inciso IV.

${ }^{136}$ Lei no ${ }^{\circ} .12 .651$ de 25-05-2012, artigo 17, §4º, incluído pela Medida Provisória nº 571 de 2012.

${ }^{137}$ Lei ${ }^{\circ}$. 12.651 de 25-05-2012, artigo 13, §2 ${ }^{\circ}$.

${ }^{138}$ Lei no ${ }^{\circ}$. 12.651 de 25-05-2012, artigo 15, caput, incisos I a III.
} 
Tal cômputo aplica-se a todas as modalidades de cumprimento da Reserva Florestal legal, incluindo-se a regeneração, a recomposição e em caso de instituição dessas áreas em regime de condomínio, também a compensação. ${ }^{139}$

$\mathrm{Na}$ verdade, para uma maior proteção ambiental e em especial da flora brasileira, a disposição do Código de 1965 de que as áreas de preservação permanente não deveriam ser computadas no percentual de Reserva Florestal Legal, a não ser que se somadas excedessem tais percentuais, deveria prevalecer, uma vez que possuem funções ambientais distintas e, conforme nos ensina Maria Luiza Machado Granziera, a ideia que permeia o instituto da Reserva Florestal Legal é, justamente, "buscar a conjugação desses espaços com outras áreas protegidas, como é o caso das Áreas de Preservação Permanente, ou das Unidades de Conservação, formando os chamados corredores ecológicos.”140

É por esse motivo que, apesar de caber ao proprietário instituir a área de Reserva Florestal Legal, a sua localização dependerá de aprovação do órgão estadual integrante do SISNAMA ou por instituição por ele habilitada, que levará em consideração determinados critérios e instrumentos estabelecidos em lei, que serão posteriormente descritos. ${ }^{141}$

As pequenas propriedades e as posses rurais familiares que já recebiam tratamento diferenciado pelo Código Florestal de 1965 foram contempladas mais ainda pela atual legislação, pois, dentre outros benefícios que serão ao longo deste trabalho destacados, para o cumprimento da manutenção da área de Reserva Florestal Legal poderão computar “os plantios de árvores frutíferas ornamentais ou industriais, compostos por espécies exóticas, cultivadas em sistema intercalar ou em consórcio com espécies nativas da região em sistemas agroflorestais”. 142

\subsubsection{Zoneamento Ecológico-Econômico}

A origem do zoneamento está diretamente relacionada à matéria urbanística, uma vez que era tido como um instrumento de regulação e ordenação da ocupação do solo urbano. Atualmente, o seu conceito está alargado ao ser considerado como um instrumento jurídico que além de ordenar a ocupação do solo urbano irá funcionar, também, como uma medida de proteção ambiental. É o que se extrai da inserção desse instituto como um dos instrumentos

\footnotetext{
${ }^{139}$ Lei n $^{\circ} .12 .651$ de 25-05-2012, artigo 15, §3º com redação dada pela Medida Provisória nº 571 de 2012.

${ }^{140}$ GRANZIERA, Maria Luiza Machado. Direito Ambiental. $2^{\mathrm{a}}$ ed. São Paulo: Atlas, 2011. p. 473.

${ }^{141}$ Lei $n^{\circ}$. 12.651 de 25-05-2012, artigo $14, \S 1^{\circ}$.

${ }^{142}$ Lei $^{\circ}$. 12.651 de 25-05-2012, artigo 54, caput.
} 
da Política Nacional do Meio Ambiente, com previsão na Lei 6.938 de 1981 em seu artigo 9º, inciso II.

O zoneamento ambiental é um instrumento de planejamento do território nacional que visa ordenar e regular o uso e a ocupação do meio ambiente, regulando, também, a utilização dos recursos naturais dele provenientes. A sua importância reside no fato de que se ocupa tanto das atividades humanas que usufruem dos espaços naturais para a sua realização, tais como o solo, os biomas e etc., quanto das exigências ecológicas necessárias à proteção de tais espaços, objetivando conciliá-las, de modo que não ocorra a contraposição de tais interesses. $^{143}$

Assim, o Poder Público irá através do zoneamento ambiental delimitar áreas destinadas ao exercício de certas atividades, as quais só poderão ser exercidas dentro desses limites, levando-se em consideração as características ambientais de cada área e atentando-se, ainda, para o interesse e bem-estar geral, de toda a sociedade.

Paulo de Bessa Antunes explica que a imposição de restrições ao uso de determinado espaço geográfico é de observância obrigatória tanto para o Poder Público quanto para o particular e, por este motivo, caracteriza-se como uma limitação administrativa do direito de propriedade. $^{144}$

Já José Afonso da Silva afirma ser o zoneamento ambiental um instrumento de que dispõe o Poder Público de intervir no domínio da propriedade e conformá-la à sua função social, inclusive com a função socioambiental, afastando-se assim da concepção de que o zoneamento ambiental seria mais uma expressão do poder de polícia concedido à Administração Pública. ${ }^{145}$

De fato, o zoneamento ambiental constitui uma limitação imposta pelo Poder Público às propriedades em geral, uma vez que estas deverão respeitar a divisão do território em áreas específicas para a realização de determinadas atividades, adequando, assim, o seu uso, bem como a sua instituição, aos regramentos de ocupação por ele determinados, os quais irão considerar, ainda, as funções ecológicas de cada área e o interesse social, o que configura a função social e socioambiental da propriedade.

\footnotetext{
${ }^{143}$ MILARÉ, Édis. Direito do Ambiente: a gestão ambiental em foco: doutrina, jurisprudência, glossário. $7^{\mathrm{a}}$ ed. São Paulo: Revista dos Tribunais, 2011. p. 452

${ }^{144}$ ANTUNES, Paulo de Bessa. Direito Ambiental. 12a ed. Rio de Janeiro: Lumen Iuris, 2010. p. 192.

${ }^{145}$ SILVA, José Afonso da. Direito Ambiental Constitucional. São Paulo: Malheiros, 2011. p. 278-279.
} 
Como um importante instrumento de proteção ao meio ambiente e prevenção dos danos eventualmente por ele sofridos, o zoneamento ambiental, conforme já mencionado, foi inserido na Política Nacional do Meio Ambiente e, posteriormente, regulamentado pelo Decreto $n^{0}$. 4.297 de 10 de Julho de 2002 com as alterações introduzidas pelos Decretos $n^{\circ}$ s. 6.288 de 2007 e 7.378 de 2010.

O decreto regulamentador estabelece os critérios que deverão ser observados pelo zoneamento ambiental, sendo por ele denominado de Zoneamento Ecológico-Econômico (ZEE). Assim, prevê em seu artigo $2^{\circ}$ que:

"O ZEE, instrumento de organização do território a ser obrigatoriamente seguido na implantação de planos, obras e atividades públicas e privadas, estabelece medidas e padrões de proteção ambiental destinados a assegurar a qualidade ambiental, dos recursos hídricos e do solo e a conservação da biodiversidade, garantindo o desenvolvimento sustentável e a melhoria das condições de vida da população."146

Percebe-se que o ZEE tem por escopo organizar o território conforme suas características ambientais com caráter obrigatório para a implantação de planos, obras e atividades públicas ou privadas. Significa dizer, então, que o ZEE obedece ao princípio do desenvolvimento sustentável, sendo uma materialização deste, pois visa compatibilizar o desenvolvimento econômico com a proteção ambiental de determinados espaços por ele abrangidos.

Por este motivo, ao distribuir espacialmente as atividades econômicas, o ZEE deverá levar em consideração a importância ecológica, as limitações e as fragilidades dos ecossistemas, determinando, inclusive, quando for o caso, a relocalização de atividades incompatíveis com a suas diretrizes gerais. ${ }^{147}$

Ao versar sobre o conteúdo do ZEE, o Decreto $\mathrm{n}^{\circ}$. 4.297 de 2002, em seu artigo 11, caput, reforça a ideia de preservação ambiental e desenvolvimento sustentável ao dispor que “o ZEE dividirá o território em zonas, de acordo com as necessidades de proteção, conservação e recuperação dos recursos naturais e do desenvolvimento sustentável.”

Ademais, o seu processo de elaboração e implementação

"I - buscará a sustentabilidade ecológica, econômica e social, com vistas a compatibilizar o crescimento econômico e a proteção dos recursos naturais, em favor das presentes e futuras gerações, em decorrência do reconhecimento de valor intrínseco à biodiversidade e a seus componentes;

II - contará com ampla participação democrática, compartilhando suas ações e responsabilidades entre os diferentes níveis da administração pública e da sociedade civil; e

\footnotetext{
${ }^{146}$ Decreto $n^{\circ} .4 .297$ de 10-07-2002, artigo $2^{\circ}$.

${ }^{147}$ Decreto $n^{\circ} .4 .297$ de 10-07-2002, artigo $3^{\circ}$, parágrafo único.
} 
III - valorizará o conhecimento científico multidisciplinar."148

Resta comprovado, por este último item, a peculiaridade do bem ambiental, que envolve, necessariamente, diversas áreas do saber científico. Para a elaboração do ZEE, importante instrumento de proteção ambiental, não poderia ser diferente, sendo, então, necessária a atuação de especialistas de diferentes áreas da ciência, bem como a atuação da sociedade civil.

Além disso, o ZEE tem como objetivo geral organizar as decisões dos agentes públicos e privados quanto aos planos, programas e atividades que utilizem direta ou indiretamente os recursos naturais. Tal organização se dará de forma vinculada e deverá assegurar a plena manutenção do capital e dos serviços ambientais dos ecossistemas. ${ }^{149}$

Ao dividir o território em zonas, o ZEE deverá considerar as necessidades de proteção, conservação e recuperação dos recursos naturais e do desenvolvimento sustentável.

A sua elaboração, com observância às diretrizes expostas acima, compete ao Poder Público Federal, nos limites nacional e regional ${ }^{150}$, quando "tiver por objeto biomas brasileiros ou territórios abrangidos por planos e projetos prioritários estabelecidos pelo Governo Federal.”151

Nesse sentido, conforme afirma Maria Luiza Machado Granziera, o zoneamento ambiental está diretamente relacionado à competência material da União Federal de elaborar e executar planos nacionais e regionais de ordenação do território e de desenvolvimento econômico e social, estabelecida pela Constituição Federal em seu artigo 21, inciso IX. ${ }^{152}$

No entanto, a participação dos Estados na elaboração e execução do ZEE poderá ocorrer mediante a celebração do termo apropriado, cumpridos os requisitos previstos no Decreto $n^{\circ} .4 .297$ de 2002.

Conforme observa Édis Milaré, apesar de o Poder Público Municipal ter sido quase ignorados pelo decreto que regulamenta o ZEE, ele “não está, todavia, impedido de desempenhar suas atribuições específicas através do Plano Diretor (...).”153

\footnotetext{
${ }^{148}$ Decreto $^{\circ}$. 4.297 de 10-07-2002, artigo $4^{\circ}$, inciso I a III.

${ }^{149}$ Decreto $n^{\circ}$. 4.297 de 10-07-2002, artigo $3^{\circ}$, caput.

${ }^{150}$ Decreto $n^{\circ}$. 4.297 de 10-07-2002, artigo 6º $-\mathrm{A}, \S 3^{\circ}$, incluído pelo Decreto $\mathrm{n}^{\circ}$. 6.288 de 2007: "Para fins do disposto neste Decreto, considera-se região ou regional a área que compreende partes de um ou mais Estados".

${ }^{151}$ Decreto n $^{\circ} .4 .297$ de 10-07-2002, artigo 6º , caput com redação dada pelo Decreto n ${ }^{\circ} .6 .288$ de 2007.

${ }^{152}$ GRANZIERA, Maria Luiza Machado, Direito Ambiental. $2^{\mathrm{a}}$ ed. São Paulo: Atlas, 2011. p. 430.

153 MILARÉ, Édis. Direito do ambiente: a gestão ambiental em foco: doutrina, jurisprudência, glossário. $7^{\mathrm{a}}$ ed. São Paulo: Revista dos Tribunais, 2011. p. 458.
} 
O Poder Público Federal, então, deverá reunir e sistematizar todas as informações geradas, inclusive pelos Estados e Municípios, bem como disponibilizá-las publicamente. ${ }^{154}$ Além disso, poderá a União Federal reconhecer os ZEE estaduais, regionais e locais, desde que tenham cumprido determinados requisitos estabelecidos pelo Decreto $\mathrm{n}^{\circ}$. 4.297 de 2002, para fins de uniformidade e compatibilização com as políticas públicas federais. ${ }^{155}$

O ZEE da Amazônia Legal, o qual está diretamente relacionado à possibilidade de redução do percentual de Reserva Florestal Legal nessa região, deverá ser elaborado pelo Poder Público Federal sob a coordenação da Comissão Coordenadora do ZEE do Território Nacional ${ }^{156}$, com a participação, ainda, de Estados e Municípios, Comissões Estaduais do ZEE e de representações da sociedade. ${ }^{157}$

Constata-se a importância dessa região para a conservação da biodiversidade brasileira diante dessa imposição especial quanto à forma de elaboração de seu ZEE, que contará com a participação, inclusive, de representações da sociedade civil.

Entretanto, não obstante ter o Código Florestal estabelecido uma situação capaz de reduzir a área protegida na Amazônia Legal, o decreto em comento estabelece em seu artigo 19, $\S 3^{\circ}$ que a alteração do ZEE não poderá reduzir o percentual da reserva legal definido na legislação específica.

\subsection{Localização das áreas de Reserva Florestal Legal}

O artigo 14, $\S 1^{\circ}$ da Lei $n^{\circ}$. 12.651/2012 estabelece que a localização da Reserva Florestal Legal deverá ser aprovada pelo órgão estadual integrante do SISNAMA ou outra instituição por ele habilitada.

Tal aprovação só se dará se forem observados os seguintes estudos e critérios:

"I- o plano de bacia hidrográfica;

II- o Zoneamento Ecológico-Econômico;

III - a formação de corredores ecológicos com outra Reserva Lega, com Área de Preservação Permanente, com Unidades de Conservação ou com outra área legalmente protegida;

IV- as áreas de maior importância para a conservação da biodiversidade; e

$\mathrm{V}$ - as áreas de maior fragilidade ambiental.” ${ }^{158}$

O critério de proximidade da Reserva Florestal Legal com outras áreas ambientalmente protegidas é extremamente relevante do ponto de vista protecionista, pois

\footnotetext{
${ }^{154}$ Decreto $n^{\circ} .4 .297$ de 10-07-2002, artigo 6º ${ }^{\circ} 2^{\circ}$ com redação dada pelo Decreto $n^{\circ}$. 6.288 de 2007.

${ }^{155}$ Decreto $n^{\circ}$. 4.297 de 10-07-2002, artigo 6º-B incluído pelo Decreto ${ }^{\circ}$. 6.288 de 2007.

${ }^{156}$ Decreto $n^{\circ}$. 4.297 de 10-07-2002, artigo 6º-C, caput, incluído pelo Decreto ${ }^{\circ}$. 6.288 de 2007

${ }^{157}$ Decreto $\mathrm{n}^{\circ}$. 4.297 de 10-07-2002, artigo 6º-C, parágrafo único incluído pelo Decreto $\mathrm{n}^{\circ} .6 .288$ de 2007

${ }^{158}$ Lei $\mathrm{n}^{\mathrm{o}}$. 12.651 de 25-05-2012, artigo 14, incisos I a V.
} 
otimiza a função ecológica de ambas as áreas ao possibilitar a formação de grandes espaços de conservação da biodiversidade, evitando-se a fragmentação e o isolamento dos mesmos e garante, conforme nos ensina Maria Luiza Machado Granziera, “a transferência de genes entre as populações de mesma espécie.”159

\subsection{Regime de Manejo Florestal Sustentável}

A Lei nº 12.651/2012, assim como o Código Florestal de 1965, proíbe a supressão da vegetação das áreas instituídas como Reserva Florestal Legal, isto é, é vedado o corte raso da vegetação. No entanto, não inviabiliza a sua utilização, prevendo que poderá ser implantado o uso compatível com a sua razão de ser, qual seja a proteção e preservação ambiental, o qual recebe a denominação de regime de manejo florestal sustentável, de acordo com as modalidades por ela previstas. ${ }^{160}$

O manejo sustentável a ser realizado na pequena propriedade ou posse rural familiar será elaborado, analisado e aprovado através de procedimentos que deverão ser simplificados pelos órgãos integrantes do SISNAMA. ${ }^{161}$

Atualmente, o Plano de Manejo Florestal Sustentável (PMFS) é regulamentado pelo Decreto 5.975 de 30.11.2006. Entretanto, a definição de manejo florestal sustentável utilizada por esse decreto é extraída da Lei $\mathrm{n}^{\circ}$. 11.284 de 02.03.2006, a qual dispõe, dentre outros assuntos, sobre a gestão das florestas públicas para a produção sustentável.

Assim, manejo florestal sustentável é

“a administração da floresta para a obtenção de benefícios econômicos, sociais e ambientais, respeitando-se os mecanismos de sustentação do ecossistema objeto do manejo e considerando-se, cumulativa ou alternativamente, a utilização de múltiplas espécies madeireiras, de múltiplos produtos e subprodutos não madeireiros, bem como a utilização de outros bens e serviços de natureza florestal."162

O PMFS é, então, entendido como o documento técnico básico que contém as diretrizes e procedimentos para a administração da floresta, visando a obtenção de benefícios econômicos, sociais e ambientais observada a definição de manejo florestal sustentável destacada acima. $^{163}$

\footnotetext{
${ }^{159}$ GRANZIERA, Maria Luiza Machado. Direito Ambiental. $2^{\mathrm{a}}$ ed. São Paulo: Atlas, 2011. p. 476.

${ }^{160}$ Lei no ${ }^{\circ} .12 .651$ de 25-05-2012, artigo 17, caput e $\S 1^{\circ}$.

${ }^{161}$ Lei $n^{\circ} .12 .651$ de 25-05-2012, artigo 17, caput e $\S 2^{\circ}$

${ }^{162}$ Lei $\mathrm{n}^{\circ} .11 .284$ de 02-03-2006, artigo $3^{\circ}$, inciso VI.

163 Decreto $\mathrm{n}^{\circ}$. 5.975 de 30-11-2006, artigo $2^{\circ}$, parágrafo único.
} 
Tal documento deverá ser aprovado pelo órgão competente do SISNAMA e deverá observar diversos fundamentos técnicos e científicos estabelecidos pelo decreto, tais como a caracterização do meio físico e biológico, a intensidade da exploração compatível com a capacidade da floresta, o ciclo de corte compatível com o tempo de restabelecimento do volume de produto extraído da floresta, a promoção da regeneração natural da florestal, a adoção de medidas mitigadoras dos impactos ambientais e sociais, dentre outros ${ }^{164}$.

Não obstante as disposições trazidas pelo decreto em questão, a Lei nº 12.651/2012 determina que no manejo sustentável da vegetação florestal da Reserva Florestal Legal serão adotadas práticas de exploração seletiva nas modalidades de manejo sustentável sem propósito comercial para consumo na propriedade e manejo sustentável para exploração florestal com propósito comercial. ${ }^{165}$

Desta forma, o manejo sustentável com propósito comercial dependerá de autorização do órgão competente e deverá atender às diretrizes e orientações de não descaracterizar a cobertura vegetal e não prejudicar a conservação da vegetação nativa da área, assegurar a manutenção da diversidade das espécies, bem como conduzir o manejo de espécies exóticas com a adoção de medidas que favoreçam a regeneração de espécies nativas. ${ }^{166}$

Já o manejo sustentável sem propósito comercial, ou seja, aquele que será realizado para consumo no próprio imóvel, independerá de autorização dos órgãos competentes, devendo apenas ser previamente declarado ao órgão ambiental a motivação da exploração e seu respectivo volume, limitado a exploração anual de 20 (vinte) metros cúbicos. ${ }^{167}$

No que tange às pequenas propriedades ou posse rural familiar o licenciamento ambiental do PMFS comercial deverá ser realizado mediante procedimento simplificado. ${ }^{168}$

Caso o manejo sustentável madeireiro seja realizado nessas propriedades com propósito comercial direto ou indireto a autorização do órgão ambiental será simplificada, mediante a apresentação de algumas informações estabelecidas pela lei. ${ }^{169}$

Já no caso de manejo sustentável eventual e sem propósito comercial direto ou indireto, para consumo no próprio imóvel, ele independerá de autorização dos órgãos ambientais competentes, limitada a retirada anual de material lenhoso a 2 (dois) metros

\footnotetext{
${ }^{164}$ Decreto $^{\circ} .5 .975$ de 30-11-2006, artigo $2^{\circ}$, caput e artigo $3^{\circ}$, inciso I a IX.

${ }^{165}$ Lei $\mathrm{n}^{\circ}$. 12.651 de 25-05-2012, artigo 20.

${ }^{166}$ Lei no ${ }^{\circ}$ 12.651 de 25-05-2012, artigo 22 e incisos I a III.

${ }^{167}$ Lei $n^{\circ}$. 12.651 de 25-05-2012, artigo 23.

${ }^{168}$ Lei no .12 .651 de 25-05-2012, artigo 56, caput.

${ }^{169}$ Lei n $^{\circ} .12 .651$ de 25-05-2012, artigo 57, caput.
} 
cúbicos por hectare, sem exceder 15 (quinze) metros cúbicos de lenha por ano e, ainda, sem seja comprometida mais de 15\% (quinze por cento) da biomassa da Reserva Florestal Legal. 170

Entende-se por manejo eventual, sem propósito comercial, segundo o artigo 56, §3”, “o suprimento, para uso no próprio imóvel, de lenha ou madeira serrada destinada a benfeitorias e uso energético nas propriedades e posses rurais, em quantidade não superior” à 2 (dois) metros cúbicos retirados anualmente por hectare.

Por fim, cabe lembrar que o Decreto $n^{0}$. 6.514 de 2008, que dispõe sobre as infrações e sanções administrativas ao meio ambiente, dentre outras providências, prevê a aplicação de multa de $\mathrm{R} \$ 1.000,00$ (mil reais) por hectare ou fração caso o manejo florestal seja executado sem autorização prévia do órgão ambiental competente e sem a observância dos requisitos técnicos estabelecidos no PFMS ou, ainda, seja executado em desacordo com a autorização concedida. $^{171}$

\subsection{Registro da Reserva Florestal Legal no Cadastro Ambiental Rural}

A área destinada a Reserva Florestal Legal deverá ser registrada no órgão ambiental competente por meio de inscrição no Cadastro Ambiental Rural (CAR), mediante a apresentação de planta e memorial descritivo contendo a indicação das coordenadas geográficas, conforme prevê o artigo 18, caput e $\S 1^{\circ}$ da Lei n ${ }^{\circ} .12 .651 / 2012$.

O Cadastro Ambiental Rural é novidade introduzida pela referida lei e consiste em um

"registro público eletrônico de âmbito nacional, obrigatória para todos os imóveis rurais , com a finalidade de integrar as informações ambientais das propriedades e posses rurais, compondo base de dados para controle, monitoramento, planejamento ambiental e econômico e combate ao desmatamento."172

Extrai-se do dispositivo citado acima que todas as propriedades e posses rurais deverão ser inscritas no CAR, podendo tal inscrição ser requerida no prazo de 1 (um) ano, prorrogável uma única vez por igual período mediante ato do Chefe do Poder Executivo, contado a partir da implantação do cadastrado. ${ }^{173}$

\footnotetext{
${ }^{170}$ Lei $\mathrm{n}^{\mathrm{o}} .12 .651$ de $25-05-2012$, artigo $56, \S \S 1^{\circ}$ e $2^{\circ}$.

${ }^{171}$ Decreto $^{\circ}$. 6.514 de 22-07-2008, artigo 51-A, incluído pelo Decreto $n^{\circ}$. 6.686 de 2008.

${ }^{172}$ Lei $\mathrm{n}^{\circ} .12 .651$ de 25-05-2012, artigo 29, caput.

${ }^{173}$ Lei $\mathrm{n}^{\circ}$. 12.651 de 25-05-2012, artigo 29, §3 ${ }^{\circ}$.
} 
Para tanto, o proprietário ou possuidor de imóvel rural apresentará ao órgão ambiental municipal ou estadual algumas informações estabelecidas em lei, tal como a identificação do imóvel com informações acerca da localização dos remanescentes de vegetação nativa e das áreas de Reserva Florestal Legal. ${ }^{174}$

Entretanto, o fornecimento de tais informações será dispensado caso exista averbação da Reserva Florestal Legal à margem da inscrição da matriculo do imóvel rural junto ao Registro de Imóveis e esta seja suficiente à identificação do perímetro e da localização da área, sendo, entretanto, necessária a apresentação ao órgão ambiental competente da certidão do respectivo Registro de Imóveis como comprovação da averbação ou, no caso de posse rural, a apresentação do termo de ajustamento de conduta. ${ }^{175}$

Em contrapartida, os proprietários ou possuidores rurais que não possuem a área de proteção de seus imóveis devidamente averbada estarão desobrigados de fazê-lo caso requeiram o registro dos mesmos no CAR. ${ }^{176}$

A averbação da Reserva Florestal Legal era prevista pelo Código Florestal de 1965 e segundo o entendimento do Superior Tribunal de Justiça era necessária para dar conhecimentos a terceiros e delimitar a área da propriedade a ser protegida:

“Ao contrário da área de preservação permanente, para a área de reserva legal a legislação traz a obrigatoriedade de averbação na matrícula do imóvel. Tal exigência se faz necessária para comprovar a área de preservação destinada à reserva legal. Assim, somente com a averbação da área de reserva legal na matrícula do imóvel é que se poderia saber, com certeza, qual parte do imóvel deveria receber a proteção do artigo 16, §8º do Código Florestal (...).” ${ }^{177}$

Além disso, a não averbação da área de Reserva Florestal Legal seria considerada infração administrativa ambiental ${ }^{178}$ com aplicação de advertência e multa diária a partir de 11 de junho de 2012, não eximindo, ainda, o proprietário do dever de instituí-la e respeitá$\mathrm{la}^{179}$, pois, conforme manifestado pelo Superior Tribunal de Justiça no julgamento do Recurso Especial $\mathrm{n}^{\circ}$. 1060886/PR ${ }^{180}$, a averbação é um ato meramente declaratório e não constitutivo.

\footnotetext{
${ }^{174}$ Lei n ${ }^{0} 12.651$ de 25-05-2012, artigo 29, §1º, com redação dada pela Medida Provisória nº 571 de 2012.

${ }^{175}$ Lei $n^{\circ}$. 12.651 de 25-05-2012, artigo 30, caput e $\S 1^{\circ}$.

${ }^{176}$ Lei $\mathrm{n}^{\circ}$. 12.651 de 25-05-2012, artigo 18, §4 ${ }^{\circ}$.

177 Superior Tribunal de Justiça. Recurso Especial nº. 1125632/PR. Relator Ministro Benedito Gonçalves. Brasília, 20 de agosto de 2009.

${ }_{178}$ Decreto 6.514/2008, artigo 55.

${ }^{179}$ ANTUNES, Paulo de Bessa. Direito Ambiental. 12a ed. Rio de Janeiro: Lumen Juris, 2011. p. 539.

${ }^{180}$ Superior Tribunal de Justiça. Recurso Especial no ${ }^{\circ}$ 1060886/PR. Relator Ministro Luiz Fux. Brasília, 01 de dezembro de 2009.
} 
Entretanto, com as inovações introduzidas pela Lei $\mathrm{n}^{\circ}$. 12.651/2012, a averbação da Reserva Florestal Legal cedeu lugar ao registro no CAR, sendo necessário, portanto, rever os entendimentos majoritários dos tribunais superiores, bem como a aplicação de sanções e penalidades pelo seu não cumprimento.

De qualquer forma, após a averbação ou o registro no CAR, a área de Reserva Florestal Legal não poderá ter a sua destinação alterada em caso de transmissão, a qualquer título, ou de desmembramento. ${ }^{181}$

Cumpre destacar que tal como era no Código de 1965 ao versar sobre a averbação, a atual legislação florestal prevê a gratuidade do registro das áreas de Reserva Florestal Legal nas pequenas propriedades ou posse rural, devendo o Poder Público prestar apoio técnico e jurídico. Ademais, o procedimento de registro para estes imóveis será simplificado, sendo ambos os dispositivos concessões especiais à estes proprietários rurais por conta de suas singularidades. $^{182}$

Nos casos de posse rural, a obrigação de manter ou instituir a área de Reserva Florestal Legal será assegurada por Termo de Ajustamento de Conduta a ser firmado entre o possuidor e o órgão competente do SISNAMA, o qual terá força de título executivo extrajudicial e deverá conter, no mínimo, informações acerca da localização da área e das obrigações assumidas pelo possuidor. ${ }^{183}$

\subsection{A Reserva Florestal Legal como obrigação}

O Superior Tribunal de Justiça firmou o entendimento de que a Reserva Florestal Legal é uma característica do imóvel, sendo uma obrigação propter rem, ou seja, um ônus real que recai diretamente sobre a coisa, obrigando o proprietário ou qualquer pessoa que venha a adquirir essa condição, independente da forma de aquisição:

"Esta corte Superior tem o entendimento sedimentado no sentido de que os deveres associados à APPs e à Reserva Legal têm natureza de obrigação propter rem, isto é, aderem ao título de domínio ou posse."184

Ainda que tal entendimento tenha sido esculpido com base no Código Florestal de 1965, parece plausível que o mesmo permaneça, uma vez que os dispositivos da Lei $\mathrm{n}^{\circ}$.

\footnotetext{
${ }^{181}$ Lei no. 12.651 de 25-05-2012, artigo 18, caput.

${ }^{182}$ Lei n ${ }^{\circ} .12 .651$ de 25-05-2012, artigo 53, parágrafo único e artigo 55.

${ }^{183}$ Lei no $^{\circ}$. 12.651 de 25-05-2012, artigo 18, §2º.

${ }^{184}$ Superior Tribunal de Justiça. Agravo Regimental no Recurso Especial no ${ }^{\circ}$ 1206484/SP. Relator Ministro Humberto Martins, Brasília, 17 de março de 2011.
} 
12.651/2012 ao alterarem o regime jurídico da Reserva Florestal Legal demonstram ser a mesma uma obrigação que se transfere com a propriedade, independente da pessoa física do proprietário, como por exemplo, o artigo 18, $\S 2^{\circ}$, ao prever que a transferência da posse implica a sub-rogação das obrigações assumidas no termo de ajustamento de conduta e o artigo 66, $\S 1^{\circ}$ ao dispor que a obrigação de regularizar a área de Reserva Florestal Legal consolidada tem natureza real, sendo transmitida ao sucessor em caso de transferência de domínio ou posse.

Portanto, o adquirente de uma propriedade sem demarcação da área de Reserva Florestal Legal não está exonerado da obrigação de instituí-la, visto que adquire a propriedade com todos os ônus nela existentes à época de sua transmissão. ${ }^{185}$

Ademais, caso a propriedade adquirida esteja desmatada, o novo proprietário terá a obrigação de reparar esse dano ambiental, conforme reiterados julgamentos do Superior Tribunal de Justiça:

"Descabe falar em culpa ou nexo causal, como fatores determinantes do dever de recuperar a vegetação nativa e averbar a Reserva Legal por parte do proprietário ou possuidor, antigo ou novo, mesmo se o imóvel já estava desmatado quando de sua aquisição. Sendo a hipótese de obrigação propter rem, desarrazoado perquirir quem causou o dano ambiental in casu, se o atual proprietário ou os anteriores, ou a culpalidade de quem o fez ou deixou de fazer."

\subsection{Recomposição, Regeneração Natural e Compensação da Reserva Florestal Legal}

A Lei $n^{\circ}$. 12.651/2012, conforme já mencionado, instituiu o conceito de áreas rurais consolidadas. Tratam-se, consoante o artigo $3^{\circ}$, inciso IV, de áreas com ocupação antrópica preexistente a 22 de julho de 2008.

Desta forma, a referida lei dedica uma seção às “áreas consolidadas em áreas de Reserva Legal”, sendo estas aquelas que em 22 de julho de 2008 detinham áreas de Reserva Florestal Legal em percentuais inferiores aos estabelecidos pela lei, prevendo medidas que poderão ser adotadas, independentemente de adesão ao Programa de Regularização Ambiental (PRA), isoladas ou conjuntamente, para a sua regularização.

Esta regularização, segundo o artigo $66, \$ 1^{\circ}$, tem natureza real, isto é, transmite-se aos sucessores tanto em caso de transferência de domínio como em caso de transferência de

\footnotetext{
${ }^{185}$ GRANZIERA, Maria Luiza Machado. Direito Ambiental. 2a ed. São Paulo: Atlas, 2011. p. 478 e 479.

${ }^{186}$ Superior Tribunal de Justiça. Recurso Especial nº 948921/SP. Relator Ministro Herman Benjamin. Brasília, 23 de outubro de 2007.
} 
posse, traduzindo o caráter de obrigação propter rem do instituto da Reserva Florestal Legal, o que já foi devidamente explicado.

Antes de adentrar-se ao conteúdo das medidas, cabe tecer alguns esclarecimentos sobre o PRA, por ser este outra novidade introduzida pela lei em comento, previsto em seu artigo 59.

Como seu próprio nome já diz, trata-se de um programa que deverá ser implementado pela União, estados e Distrito Federal no prazo de 1 (um ano) contado da publicação da lei, ou seja, de 28 de maio de 2012 com o objetivo de adequar as propriedades e posses rurais ao termos ambientais estabelecidos por esta nova legislação florestal. ${ }^{187}$

À União caberá a instituição de normas gerais sobre a regularização das propriedades rurais, enquanto que aos Estados e ao Distrito Federal caberá a edição de normas de caráter específico, estabelecendo o detalhamento do programa de acordo com as suas peculiaridades territoriais, climáticas, históricas, culturais, econômicas e sociais. ${ }^{188}$

O registro do imóvel no CAR é condição obrigatória para a sua adesão ao Programa de Regularização Ambiental. Tal adesão poderá ser requerida dentro do prazo de 1 (um) ano contado a partir da implementação do programa e ensejará na elaboração de Termo de Ajustamento de Conduta, no qual o proprietário ou possuidor irá obrigar-se a regularizar sua propriedade de acordo com as condições estabelecidas pelo programa, constituindo título executivo extrajudicial, isto é, a simples apresentação do termo de compromisso em juízo é suficiente para gerar a responsabilização legal de quem o firmou. ${ }^{189}$

O $\S 4^{\circ}$ do artigo 59 da Lei $\mathrm{n}^{\circ}$. 12.651/2012 complementa a normatização do PRA estabelecendo que:

"No período entre a publicação desta Lei e a implementação do PRA em cada Estado e no Distrito Federal, bem como após a adesão do interessado ao PRA e enquanto estiver sendo cumprido o termo de compromisso, o proprietário ou possuidor não poderá ser autuado por infrações cometidas antes de 22 de julho de 2008, relativas à supressão irregular de vegetação em Áreas de Preservação Permanente, de Reserva Legal e de uso restrito.”

Percebe-se, então, que a referida lei criou uma situação de anistia aos proprietários que desmataram áreas de Reserva Florestal Legal antes de 22 de julho de 2008, tendo em vista que os mesmos não poderão ser autuados por tais infrações, o que vai de encontro ao objetivo

\footnotetext{
${ }^{187}$ Lei n ${ }^{\circ} .12 .651$ de 25-05-2009, artigo 59, caput.

${ }^{188}$ Lei $n^{\circ} .12 .651$ de 25-05-2009, artigo 59, $\S 1^{\circ}$.

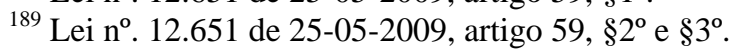


primordial da legislação florestal, qual seja proteger, conservar as florestas e demais formas de vegetação assim como regulamentar a sua exploração.

Nesse mesmo sentido, o $\S 5^{\circ}$ do mesmo artigo amplia o perdão concedido a tais proprietários ao prever a suspensão das sanções decorrentes da infração acima mencionada após a assinatura do termo de compromisso. Caso todas as obrigações estabelecidas neste termo sejam cumpridas dentro de seus limites temporais, as multas serão convertidas em serviços de preservação, melhoria e recuperação da qualidade do meio ambiente, regularizando o uso das áreas consolidadas em conformidade com o PRA. ${ }^{190}$

Não obstante tais disposições, a Lei no . 12.651/2012 prevê ainda outras concessões de anistia à imóveis rurais quanto à manutenção da Reserva Florestal Legal. Assim, dispõe o artigo 67 que a Reserva Florestal Legal das propriedades rurais que em 22 de julho de 2008 não excediam a área de 4 (quatro) módulos fiscais será constituída pela área ocupada com a vegetação nativa existente àquela data, ainda que atualmente possuam remanescentes de vegetação nativa em percentuais inferiores aos estabelecidos por essa lei.

Do mesmo modo, estão desonerados de cumprir com a obrigação de recompor, compensar ou regenerar a Reserva Florestal Legal aqueles proprietários ou possuidores de imóveis rurais que realizaram a supressão de vegetação nativa com respaldo em legislação florestal que vigorava à época da supressão. ${ }^{191}$

Ressalta-se que tais disposições são contrárias ao objetivo do instituto da Reserva Florestal Legal. Permite o aumento de áreas degradadas, uma vez que não serão necessariamente recuperadas, além de possibilitar que ocorram novos desmatamentos nessas propriedades, o que será especialmente discutido no último capítulo da presente monografia.

Após breve exposição sobre o PRA, procede-se agora à análise das medidas propostas pela Lei $n^{\circ}$. 12.651/2012 para a adequação das áreas consolidadas às atuais exigências ambientais.

Assim, a primeira medida consiste na recomposição da área de Reserva Florestal Legal, que deverá ser concluída em até 20 (vinte) anos, abrangendo a cada 2 (dois) anos, no mínimo 1/10 (um décimo) da área total necessária à sua complementação, atendendo, ainda, à critérios estipulados pelo órgão competente do SISNAMA. ${ }^{192}$

\footnotetext{
${ }^{190}$ Lei $n^{\circ}$. 12.651 de 25-05-2009, artigo 59, $§ 5^{\circ}$.

${ }^{191}$ Lei $n^{\circ} .12 .651$ de 25-05-2009, artigo 68.

${ }^{192}$ Lei $\mathrm{n}^{\circ}$. 12.651 de 25-05-2009, artigo 66, inciso I e $2^{\circ}$.
} 
Tal recomposição poderá ser realizada mediante o plantio intercalado de espécies exóticas e nativas, em sistema agroflorestal, desde que o plantio de espécies exóticas seja combinado com as espécies nativas de ocorrência regional e a área recomposta de espécies exóticas não exceda a 50\% (cinquenta por cento) da área total a ser recuperada. ${ }^{193}$

Caso a propriedade em que a recomposição irá ocorrer seja pequena propriedade ou posse rural familiar o poder público estadual estará obrigado a fornecer apoio técnico ${ }^{194}$. Esta disposição denota a preocupação do legislador florestal com as pequenas propriedades rurais ou posse rural familiar, prevendo para elas tratamento diferenciado devido às suas características de exploração e tamanho ${ }^{195}$.

Cumpre observar que essa medida prevista pela legislação florestal não viabiliza a supressão da vegetação das áreas de Reserva Florestal Legal sob o argumento de serem posteriormente recompostas. A recomposição admitida por esse dispositivo normativo referese somente às situações passadas ocorridas antes do marco temporal por ela estabelecido, qual seja, 22 de julho de 2008. Destruir ou danificar florestas plantadas ou nativas, objeto de especial preservação tal como ocorre com a Reserva Florestal Legal é considerado crime ${ }^{196}$.

A segunda medida consiste em permitir a regeneração natural da área de Reserva Florestal Legal $^{197}$. É, na verdade, conforme nos ensina José Afonso da Silva, “um processo de auto-recomposição florística, ou seja, pelo próprio renascimento da flora destruída; mas isso só é possível quando o processo de desmatamento ou outra forma de destruição deixam restos suscetíveis de brotar e desenvolver” ${ }^{198}$.

Portanto, a possibilidade de regeneração da vegetação dependerá do grau de perturbação por ela sofrida, bem como da maneira que o ambiente foi degradado. Caso a perturbação seja muito intensa, a recuperação espontânea da área poderá ser inviável ou ocorrer somente após significativo lapso temporal, desde que os fatores causadores da degradação ambiental sejam reduzidos ou retirados. ${ }^{199}$

Ademais, aquele que impedir ou dificultar a regeneração natural de florestas ou demais formas de vegetação localizadas, dentre outras áreas, na área de Reserva Florestal Legal

\footnotetext{
${ }^{193}$ Lei $n^{\circ}$. 12.651 de 25-05-2009, artigo 59, §3º.

${ }^{194}$ Lei $n^{\circ} .12 .651$ de 25-05-2012, artigo 54, parágrafo único.

${ }^{195}$ Lei $^{\circ}$. 12.651 de 25-05-2012, artigo $3^{\circ}$, inciso V e Lei $n^{\circ}$. 11.326 de 24-07-2006, artigo $3^{\circ}$, inciso I a IV.

${ }^{196}$ Lei 9.605 de 12 de fevereiro de 1998, artigo 50.

${ }^{197}$ Lei n ${ }^{\circ}$. 12.651 de 25-05-2012, artigo 66, inciso II.

198 SILVA, José Afonso da. Direito Ambiental Constitucional. 9a ed. São Paulo: Malheiros, 2011. p. 195.

${ }^{199}$ SÁNCHES, Luis Enrique. Avaliação de Impacto Ambiental: conceito e métodos. São Paulo: Oficina de Textos, 2008. p. 27.
} 
estará sujeito ao pagamento de multa de R\$ 5.000,00 (cinco mil reais), por hectare ou fração, conforme previsto pelo Decreto $\mathrm{n}^{0}$. 6.514 de 22-07-2008 em seu artigo 48, caput, com redação dada pelo Decreto nº 6.686 de 2008.

A terceira e última medida proposta pela Lei $n^{0}$. 12.651/2012 é denominada de compensação. Trata-se da utilização de outra área equivalente em extensão à área de Reserva Florestal Legal a ser compensada, localizada no mesmo bioma e se fora do Estado estar localizada em áreas identificadas como prioritárias pela União ou pelos Estados. ${ }^{200}$

Conforme prevê o $\S 6^{\circ}$ do artigo 66, a identificação de áreas prioritárias por esses entes federativos deverá buscar o favorecimento da "recuperação de bacias hidrográficas excessivamente desmatadas, a criação de corredores ecológicos, a conservação de grandes áreas protegidas e a conservação ou recuperação de ecossistemas ou espécies ameaçados.”

A compensação deverá ser precedida pela inscrição da propriedade no CAR e poderá ser realizada mediante:

"I- aquisição de Cota de Reserva Ambiental - CRA;

II - arrendamento de área sob regime de servidão ambiental ou Reserva Legal;

III - doação ao poder público de área localizada no interior de Unidade de Conservação de domínio público pendente de regularização fundiária;

IV - cadastramento de outra área equivalente e excedente à Reserva Legal, em imóvel de mesma titularidade ou adquirida em imóvel de terceiro, com vegetação nativa estabelecida, em regeneração ou recomposição, desde que localizada no mesmo bioma., ${ }^{201}$

As duas primeiras hipóteses de compensação, quais sejam a Cota de Reserva Ambiental e o regime de servidão ambiental, são instrumentos revestidos de cunho econômico que serão mais a frente trabalhados. Quanto à terceira hipótese, trata-se de norma muito semelhante ao artigo $44, \S 6^{\circ}$ do Código Florestal de 1965 , que previa que o proprietário rural poderia ser desonerado de obrigação de recompor a Reserva Florestal Legal caso realizasse a doação acima descrita ao órgão ambiental.

Édis Milaré ao discorrer sobre a razão de ser do dispositivo original do Código de 1965 destaca a observação realizada por Andrea Vulcanis que afirma que:

“A proteção efetiva de áreas protegidas através de sua incorporação ao patrimônio público possui, do ponto de vista axiomático, valor maior que a recomposição da reserva legal inexistente ou incompleta na propriedade privada.,"202

\footnotetext{
${ }^{200}$ Lei $n^{\circ} .12 .651$ de 25-05-2012, artigo 66, $\S 6^{\circ}$.

${ }^{201}$ Lei $\mathrm{n}^{\circ}$. 12.651 de 25-05-2012, artigo 66, §5º.

${ }^{202}$ MILARÉ, Édis. Direito do ambiente: a gestão ambiental em foco: doutrina, jurisprudência, glossário. $7^{a}$ ed. São Paulo: Revista dos Tribunais, 2011. p. 978.
} 
Já a quarta hipótese trata da compensação típica, ou seja, a utilização de área coberta de vegetação em outro imóvel, desde que localizado no mesmo bioma.

A compensação, então, permite que a área de proteção de uma propriedade seja constituída por um espaço coberto de vegetação de outra propriedade, diversa daquela, o que, no entanto, não a exime de respeitar também os percentuais de Reserva Florestal Legal exigidos para a sua área. ${ }^{203}$

Além disso, a compensação não poderá viabilizar a conversão de novas áreas para uso alternativo do solo. ${ }^{204}$ Entende-se por uso alternativo do solo da substituição da cobertura vegetal do solo por qualquer forma de ocupação humana.

No que se refere aos imóveis públicos devedores de áreas de Reserva Florestal Legal, a Lei $\mathrm{n}^{\circ}$. 12.651/2012 estabelece que a sua compensação poderá ser feita mediante concessão de direito real de uso ou doação de área localizada em Unidade de Conservação de domínio público, a ser criada ou pendente de regularização fundiária. ${ }^{205}$

\subsubsection{Servidão Ambiental}

O instituto da servidão florestal era previsto no artigo 44-A, caput, do Código Florestal de 1965 como a possibilidade de o proprietário rural renunciar voluntariamente em caráter temporário ou permanente o direito de supressão ou exploração da vegetação nativa, localizada fora da Reserva Florestal Legal, instituindo sobre ela o regime de servidão florestal.

Com a promulgação da Lei $\mathrm{n}^{0}$. 12.651/2012, o instituto da servidão florestal foi revogado, existindo hoje somente o instituto da servidão ambiental regido pela Lei $\mathrm{n}^{\circ}$. 6.938/81, que institui a Política Nacional do Meio Ambiente, a qual também sofreu as alterações introduzidas pela nova lei florestal, porém somente no que concerne a este instituto. No entanto, a sua definição não sofreu significativas alterações, conforme se depreende da redação do artigo $9^{\circ}$-A:

“O proprietário ou possuidor de imóvel, pessoa natural ou jurídica, pode, por instrumento público ou particular ou por termo administrativo firmado perante órgão integrante do SISNAMA, limitar o uso de toda a sua propriedade ou de parte dela para preservar, conservar ou recuperar os recursos ambientais existentes, instituindo servidão ambiental."206

\footnotetext{
${ }^{203}$ GRANZIERA,Maria Luiza Machado. Direito Ambiental. $2^{\mathrm{a}}$ ed. São Paulo: Atlas, 2011. p. 481.

${ }^{204}$ Lei $n^{\circ}$. 12.651/2012 de 25-05-2012, artigo 66, §9 .

${ }^{205}$ Lei $n^{\circ} .12 .651$ de 25-05-2012, artigo 66, §8 ${ }^{\circ}$.

${ }^{206}$ Lei no . 6.938/1981 de 31-08-1981, artigo 9-A, com redação dada pela Lei no ${ }^{\circ}$ 12.651/2012.
} 
Conforme o entendimento de José Afonso da Silva, esse instituto não é uma servidão típica definida pelo Código Civil $^{207}$, pois não há a relação entre prédio dominante e prédio serviente, sendo este útil ao primeiro. Segundo o autor, existe, na verdade, "uma aparência de servidão porque existe um vínculo entre o bem serviente (a floresta) e o interesse ambiental, mas ocorre também na reserva legal”. ${ }^{208}$

A servidão ambiental é uma forma de compensação da Reserva Florestal Legal que será realizada mediante o arrendamento da área sobre a qual recaiu a renúncia ao direito de supressão e exploração da vegetação pelo proprietário rural que não possui em sua propriedade área de Reserva Florestal Legal. Para tanto, deverá ser celebrado o contrato de arrendamento entre os proprietários rurais, definido pelo artigo $9^{\circ}$-A, $§ 1^{\circ}$ da Lei 6.938/1981 como instrumento ou termo de instituição de servidão ambiental, materializando, assim, a vontade de ambos.

Tal termo deverá conter, no mínimo, o memorial descritivo da área de servidão ambiental, o seu objeto, bem como os direitos e deveres do proprietário ou possuidor instituidor e o prazo durante o qual a área permanecerá como servidão ambiental. ${ }^{209}$

O cunho econômico desse instituto reside no fato de que o mesmo poderá ser oneroso, isto é, o arrendamento ocorrerá mediante o pagamento de certa quantia por aquele proprietário que não possui área de Reserva Florestal Legal, o que se torna uma alternativa de obtenção de vantagens econômicas para aquele proprietário que renuncia ao direito de supressão ou exploração da vegetação nativa de sua propriedade.

Pode ser visto também como um instrumento de incentivo de proteção ambiental e conservação florestal, uma vez que o valor econômico auferido com o arrendamento pode ser tão satisfatório quanto ao valor econômico que seria obtido com a exploração da vegetação.

Ademais, o uso da vegetação da área que se encontra sob o regime de servidão florestal deverá ser limitado, sendo no mínimo o mesmo uso previsto para as áreas de Reserva Florestal Legal. ${ }^{210}$

A constituição da servidão ambiental deverá ser averbada à margem da inscrição de matrícula do imóvel no registro de imóveis competente, sendo vedada, durante o prazo de sua

\footnotetext{
${ }^{207}$ Lei n $^{\circ} .10 .406 / 2002$, artigos 1.378 a 1.389.

${ }^{208}$ SILVA, José Afonso da. Direito Ambiental Constitucional. 9a. ed. São Paulo: Malheiros, 2011. p. 196.

${ }^{209}$ Lei $n^{\circ}$. 6.938 de 31-08-1981, artigo $9^{\circ}$-A, $\$ 1^{\circ}$, inciso I a IV com redação dada pela Lei ${ }^{\circ}$. 12.651/2012.

${ }^{210}$ Lei $^{\circ}$. 6.938 de 31-08-1981, artigo $9^{\circ}$-A, $\S 3^{\circ}$ com redação dada pela Lei no ${ }^{\circ}$ 12.651/2012.
} 
vigência, a alteração da destinação da área, nos casos de transmissão a qualquer título, de desmembramento ou de retificação dos limites da propriedade. ${ }^{211}$

Ressalta-se que diferentemente do regime de servidão disposto pelo Código Civil, a relação necessária existente na servidão florestal se dá entre os proprietário rurais envolvidos e não entre as propriedades por suas localizações, ${ }^{212}$ não sendo relevante a proximidade destas, ainda que devam obedecer aos critérios estabelecidos para a compensação.

\subsubsection{Cota de Reserva Ambiental}

O título representativo da vegetação nativa que se encontra sob o regime de servidão florestal é denominado de Cota de Reserva Ambiental (CRA). É este termo utilizado também para representar a área de Reserva Florestal Legal instituída voluntariamente sobre a vegetação que exceder os percentuais mínimos para essa área exigidos pela Lei $n^{\circ}$. 12.651/2012, ${ }^{213}$ sendo então uma possibilidade de remuneração para aquele proprietário que voluntariamente mantém área de Reserva Florestal Legal acima dos percentuais exigidos pela legislação.

Desse modo, a CRA é um instrumento revestido de cunho econômico e será adquirido por aqueles proprietários que não possuem área de Reserva Florestal Legal em conformidade com a legislação para fins de compensação ou até mesmo por aqueles interessados apenas em proteger o meio ambiente. Ademais, Maria Luiza Machado Granziera afirma que “de posse desse título, o proprietário poderá comercializá-lo,”214 o que deveria ensejar a criação de um mercado ambientalista.

Rogério da Cruz Caradori ao discorrer sobre o assunto observa que o mercado negociável ambientalista ainda está em criação de forma tímida e promissora e explica que

"possuímos a norma determinante de se constituir a devida Reserva Legal (...), e por outro lado a própria lei, fomentando esse "econegócio", permite a contratualização entre o particular exigido e o outro, desonerado legalmente, de um negócio economicamente viável para ambos e indiscutivelmente benéfico para o meio ambiente, para a sociedade moderna e para suas futuras gerações."215

Entretanto, é possível que com a promulgação da Lei $n^{0}$. 12.651/2012 o mercado ambientalista prospere, já que cumpre com a função de regulamentar a CRA, estabelecendo

\footnotetext{
${ }^{211}$ Lei n ${ }^{\circ}$. 6.938 de 31-08-1981, artigo 9-A, §§ $5^{\circ}$ e $6^{\circ}$ com redação dada pela Lei no ${ }^{\circ}$ 12.651/2012.

${ }^{212}$ GRANZIERA, Maria Luiza Machado. Direito Ambiental. $2^{\mathrm{a}}$ ed. São Paulo: Atlas, 2011. p. 483.

${ }^{213}$ Lei $n^{\circ}$. 12.651 de 25-05-2012, artigo 44, inciso I e II.

${ }^{214}$ GRANZIERA, Maria Luiza Machado. Direito Ambiental. $2^{\mathrm{a}}$ ed. São Paulo: Atlas, 2011. p. 485.

215 CARADORI, Rogério da Cruz. O Código Florestal e a legislação extravagante: a teoria e a prática da proteção florestal. São Paulo: Atlas, 2009. p. 204.
} 
suas características, natureza e mecanismos que a tornem mais segura, o que na vigência do Código Florestal de1965 era transferida a regulamento até então inexistente. 


\section{O Código Florestal de 2012 - Lei nº 12.651 de 25 de maio de 2012}

\subsection{Implicações da Lei $\mathbf{n}^{\circ}$. 12.651 de 25 de maio de 2012 nas áreas de Reserva Florestal Legal}

O Código Florestal de 1965 depois de ensejar a tramitação de diversos projetos oriundos das críticas sobre as suas leis de proteção ambiental foi, finalmente, revogado.

Tal revogação se deu com a tramitação em especial do Projeto de Lei 1.876 de 1999, que após a aprovação em ambas Casas do Congresso Nacional seguiu para a apreciação da Presidente da República, a qual em 25 de maio de 2012 divulgou os seus vetos, sanções e modificações propostas.

Assim sendo, o projeto foi transformado na lei ordinária $\mathrm{n}^{\circ}$. 12.651 de 25 de maio de 2012, publicada em 28 de maio de 2012, substituindo o até então vigente Código Florestal de 1965, instituindo-se uma nova norma de proteção florestal, ainda que não tenha sido sob essa designação.

Conforme mencionado, a Presidente da República, Dilma Roussef, propos diversas modificações à redação original do Congresso Nacional, as quais foram introduzidas na Lei nº. 12.651/2012 com a promulgação da Medida Provisória nº 571 de 25 de maio de 2012, também publicada em 28 de maio de 2012.

O processo legislativo brasileiro permite que os vetos introduzidos pela Presidente ainda sejam objeto de apreciação pelo Congresso Nacional em sessão conjunta, dentro de 30 (trinta) dias a contar de seu recebimento podendo, até mesmo, ser derrubado pelo voto da maioria absoluta de seus membros. ${ }^{216}$

Entretanto, como os referidos vetos não recaíram diretamente sob os artigos que instituem o regime jurídico das áreas de Reserva Florestal Legal, a Lei nº 12.651/2012 foi utilizada como principal fundamento jurídico deste trabalho e por isso será aqui analisada as modificações por ela introduzidas somente no que concerne a tais áreas.

Primeiramente, cumpre mencionar as motivações que desencadearam a tramitação do projeto de lei com a sua posterior aprovação.

Percebe-se que o principal objetivo das alterações da legislação florestal foi aumentar a produtividade agrícola através da diminuição de áreas de proteção florestal com o

\footnotetext{
${ }^{216}$ Constituição Federal de 1988, artigo 66, §4º
} 
argumento de que aquela estaria sendo inviabilizada diante de tamanha proteção ambiental.

A Sociedade Brasileira para Progresso da Ciência (SBPC) e a Academia Brasileira de Ciências (ABC) elaboraram extenso estudo para contribuir com o diálogo sobre a alteração da lei florestal. Neste estudo, essas instituições descartam a existência de qualquer dilema entre conservar o meio ambiente e aumentar a produção de alimentos no Brasil. ${ }^{217}$

Como fundamento para dessa afirmação, destacam que o país possui cerca de 5,5 milhões de $\mathrm{km}^{2}$ de terra "com uso potencial para os mais diversos tipos de cultivos e níveis de adoção de tecnologias." ${ }^{218}$ No entanto, 76\% (setenta e seis por cento) dessas terras encontram-se fragilizadas e que, portanto, a grande limitação do Brasil em expandir a sua produção agrícola deriva da "falta de adequação de sua política agrícola, com tecnificação dos pequenos produtores, políticas de preços agrícolas, incluindo insumos, políticas de estoques reguladores, infraestrutura de escoamento e armazenamento dos produtos agrícolas e etc. 219

Assim, as terras utilizadas tanto para a produção de grãos como as terras utilizadas com a pecuária poderiam ter a sua capacidade de produção aumentada com pequenos investimentos tecnológico, sem que fosse necessário, portanto, novos desmatamentos e diminuição das áreas de proteção ambiental.

O Brasil é um grande exportador de soja, café, açúcar, suco de laranjas e carne bovina, ocupando posição de destaque em diversos outros ramos do agronegócio. Entretanto, o uso irregular do solo, bem como o seu processo de ocupação resultaram em fortes pressões sobre o meio ambiente com o consequente desperdício dos recursos naturais, uma vez que estaimse que 61 milhões de hectares de terras poderiam ser restauradas para torná-las aptas à produção. De todo modo, tal situação necessita urgentemente ser mudada.

Além do mais, segundo as instituições acima mencionadas,

“existe um passivo da ordem de 83 milhões de hectares de áreas de preservação ocupadas irregularmente, de acordo com a legislação ambiental em vigor. Estima-se que o impacto da erosão ocasionado pelo uso agrícola das terras no Brasil é da ordem de $\mathrm{R}$ \$ 9,3 bilhões anuais, que poderiam ser revertidos pelo uso de tecnologias conservacionistas e pelo planejamento de uso da paisagem,

\footnotetext{
${ }^{217}$ O Código Florestal e a Ciência. Sociedade Brasileira para o Progresso da Ciência. Disponível em http://www.sbpcnet.org.br/site/arquivos/codigo_florestal_e_a_ciencia.pdf Acessado em 25 de maio de 2012.

${ }^{218}$ O Código Florestal e a Ciência. Sociedade Brasileira para o Progresso da Ciência. p. 9. Disponível em http://www.sbpcnet.org.br/site/arquivos/codigo_florestal_e_a_ciencia.pdf Acessado em 25 de maio de 2012.

${ }^{219}$ O Código Florestal e a Ciência. Sociedade Brasileira para o Progresso da Ciência. p. 9. Disponível em http://www.sbpcnet.org.br/site/arquivos/codigo_florestal_e_a_ciencia.pdf Acessado em 25 de maio de 2012.
} 
gerando benefícios ambientais."220

Outro argumento utilizado por aqueles que pretendiam ver o Código Florestal reformulado consiste na afirmação de que o mesmo foi votado sem a participação do setor agrícola da sociedade, sendo, por isso, uma imposição do setor ambientalista, o que não possui fundamento algum, visto que a Lei 4.771 de 15 de setembro de 1965 foi assinada por Castello Branco, à época presidente do Brasil, e logo abaixo por Hugo Leme, então Ministro da Agricultura.

De qualquer forma, a solução de reduzir as áreas de proteção ambiental não coincide com o posicionamento adotado pelo governo brasileiro, que tem como principal estratégia para a diminuição de suas emissões de gás carbônico o controle do desmatamento. Inclusive, conforme já mencionado, a majoração dos percentuais para as áreas de Reserva Florestal Legal na Amazônia Legal teve por escopo frear o desmatamento nessa região.

Diante de tamanha contribuição dos cientistas brasileiros e ainda de diversos outros setores da sociedade, tais como os advogados e magistrados, o Código Florestal de 1965 ainda assim foi revogado e a nova lei florestal não preconizou a conservação das áreas de proteção ambiental em suas disposições.

Quanto ao instituto da Reserva Florestal Legal, percebe-se já na sua definição que sua finalidade precípua foi desconstituída, introduzindo destinação econômica ao uso dos recursos naturais do imóvel rural, enquanto que o Código Florestal de 1965 determinava que as áreas de Reserva Florestal Legal eram necessárias ao uso sustentável dos recursos naturais e à conservação da biodiversidade e dos processos ecológicos.

É este o entendimento da Ordem dos Advogados do Rio de Janeiro que ao elaborar nota técnica em defesa do veto ao projeto de lei afirma que "a Reserva Legal passaria a ter a destinação econômica como finalidade. Atualmente a destinação é a conservação e o manejo". ${ }^{221}$

Com relação ao percentual de área de Reserva Florestal Legal, as disposições da Lei $\mathrm{n}^{\circ}$. 12.651/2012 coincidem com o revogado Código Florestal, quais sejam: 80\% para as propriedades situadas em áreas de florestas na Amazônia Legal; 35\% para as propriedades situadas em áreas de cerrado na Amazônia Legal; 20\% para as propriedades situadas em áreas

\footnotetext{
${ }^{220}$ O Código Florestal e a Ciência. Sociedade Brasileira para o Progresso da Ciência. p. 10. Disponível em http://www.sbpcnet.org.br/site/arquivos/codigo_florestal_e_a_ciencia.pdf Acessado em 25 de maio de 2012.

${ }^{221}$ Nota técnica elaborada pela OAB-RJ. Disponível em http://www.oabrj.org.br/detalheConteudo/217/Nota-tecnica-emdefesa-do-veto-ao-Projeto-de-Lei.html. Acessado em 21 de maio de 2012.
} 
de floresta ou outras formas de vegetação nativa nas demais regiões do Brasil e 20\% para as propriedade rurais em área de campos gerais localizadas em qualquer região do Brasil.

Entretanto, a nova legislação florestal permite, em alguns casos, a redução do percentual de $80 \%$ exigido para as propriedades rurais localizadas em áreas de floresta na Amazônia Legal.

Desta forma, conforme já analisado, a Reserva Florestal Legal poderá ser reduzida pelo Poder Público, para fins de recomposição, para até 50\% naqueles municípios que possuírem mais da metade de sua área ocupada por unidades de conservação da natureza de domínio público e terras indígenas homologadas.

Nota-se que tal redução fere diretamente o objetivo da instituição de reserva legal na região amazônica, que figura como um desincentivo ao desmatamento dessa região. Os percentuais foram majorados ao longo dos anos com a edição de diversas medidas provisórias, sendo a última delas a Medida Provisória $\mathrm{n}^{\circ}$. 2.166-67 de 2001, desde que o Instituto de Pesquisas Espaciais iniciou estudos sobre o desmatamento na região amazônica, divulgando seus altos índices.

Poderá ser reduzida, ainda, também para 50\%, quando o Estado tiver Zoneamento Ecológico Econômico aprovado e mais de 65\% do seu território ocupado por unidades de conservação da natureza de domínio público, devidamente regularizadas, e por terras indígenas homologadas, sendo que, neste caso, a redução deverá ser realizada pelo Poder Público Estadual com a oitiva do Conselho Estadual do Meio Ambiente.

O Código Florestal de 1965 já previa a redução para 50\% desde que o Zoneamento Ecológico Econômico assim indicasse. No entanto, tal redução ocorreria apenas para fins de recomposição da Reserva Legal na Amazônia Legal.

Um grande retrocesso para a preservação e conservação das florestas, previsto pela lei recentemente aprovada, consiste na possibilidade de se incluir no cômputo do percentual da Reserva Florestal Legal as áreas de preservação permanente.

O Código Florestal de 1965 permitia tal possibilidade somente se a soma de tais áreas excedesse o percentual de 80\% na propriedade rural localizada na Amazônia Legal, 50\% da propriedade rural localizada nas demais regiões do Brasil e 25\% nas pequenas propriedades, além de não poder implicar em conversão de novas áreas para uso alternativo do solo.

A lei manteve esta última exigência de que o cômputo das áreas de preservação permanente no percentual de Reserva Florestal Legal não pode implicar em conversão de 
novas áreas para o uso alternativo do solo, acrescentando que a área a ser computada deve estar conservada ou em processo de recuperação. Entretanto, ignorou a exigência mais relevante do ponto de vista protecionista, qual seja a de que o cômputo das áreas de preservação permanente na Reserva Florestal Legal só poderá ocorrer caso essa soma não exceda determinados percentuais essenciais para a proteção ambiental.

As áreas de preservação permanente exercem funções distintas das áreas de Reserva Florestal Legal. As primeiras justificam-se por protegerem o solo de fatores naturais, tais como a erosão, bem como por preservarem os recursos hídricos, a paisagem, a estabilidade geológica, a biodiversidade, o fluxo gênico de fauna e flora. ${ }^{222}$ Já as segundas têm como função conservar a biodiversidade e os processos ecológicos, bem como abrigar e proteger a fauna e a flora nativas. Ressalta-se que a fauna e a flora existentes nessas áreas não se confundem, pois são distintas e complementares.

Tal procedimento não possui justificativas científicas. Segundo a ABC e SBPC a inclusão das áreas de preservação permanente no cômputo da Reserva Florestal Legal reduzirá significativamente as áreas de proteção, o que poderá acarretar a extinção de diversas espécies e a redução da biodiversidade, uma vez que cada uma dessas áreas abriga espécies diferentes. Além disso, estabelecem que para a sobrevivência de diversas espécies faz-se necessário a manutenção de no mínimo 30\% da vegetação nativa, o que só é possível com o somatório dessas áreas. ${ }^{223}$

Percebe-se a nítida intenção do projeto de reduzir as áreas de proteção ambiental, sob o notório pretexto de que impossibilitam a expansão da produção agrícola brasileira.

É com esse intuito que a nova legislação prevê ainda a possibilidade de supressão da vegetação em áreas de Reserva Legal, mediante simples declaração do órgão ambiental competente, para a realização de determinadas atividades consideradas de baixo impacto ambiental em propriedades pequenas ou de posse rural familiar, que são aquelas exploradas mediante o trabalho pessoal do agricultor familiar e empreendedor familiar rural.

Contata-se que a Lei $\mathrm{n}^{\circ}$. 12.651/2012 visa também, então, beneficiar especialmente as pequenas propriedades e a agricultura familiar com a previsão de diversos instrumentos mais brandos no que tange às áreas de proteção florestal existentes nessas propriedades, o que não

\footnotetext{
${ }^{222}$ Lei 4.7771/61, artigo $1^{\circ}$, $\S 2^{\circ}$, II, com redação dada pela Medida Provisória $n^{\circ}$. 2.166/67, revogado pela Lei $n^{\circ}$. $12.651 / 2012$.

${ }^{223}$ Contribuições da ABC e da SBPC para o debate sobre o Código Florestal. Sociedade Brasileira para o Progresso da Ciência. Disponível em < http://www.sbpcnet.org.br/site/arquivos/arquivo_295.pdf> Acesso em 25 de maio de 2012.
} 
justifica a alteração do Código Florestal visto que este também concedia tratamento diferenciado às pequenas propriedades rurais, flexibilizando para ela o regime jurídico das áreas de proteção.

À título exemplificativo, destaca-se o revogado $\S 3^{\circ}$ do artigo 16 do Código Florestal de 1965 que possibilitava para o cumprimento da manutenção da área de Reserva Legal nas pequenas propriedades ou nas propriedades de posse rural familiar o cômputo dos plantios de árvores frutíferas, ornamentais ou industriais, compostos por espécies exóticas, cultivadas em sistema intercalar ou em consórcio com espécies nativas da região em sistemas agroflorestais, o que foi mantido pela atual legislação.

Outro retrocesso para a proteção florestal consiste na permissão de se realizar a recomposição da Reserva Florestal Legal mediante o plantio de espécies exóticas em área não superior a 50\% da área total a ser recuperada.

O Código Florestal de 1965 permitia esse modo de recomposição apenas em sua fase inicial. A ABC e a SBPC, no minucioso estudo citado, o qual foi realizado com intuito de colaborar no diálogo sobre a alteração da lei florestal, destacaram que o uso de espécies exóticas prejudica as funções primordiais da Reserva Florestal Legal, quais sejam a conservação da biodiversidade e o uso sustentável dos recursos naturais, uma vez que as espécies nativas não suportarão as condições do ambiente altamente alterado e a predominância de uma espécie de vegetação reduz a biodiversidade de um ecossistema. Destacam, ainda, que, conforme previsão da lei hoje vigente, o uso temporário dessas espécies é um instrumento de viabilização econômica da recuperação dessas áreas ao permitir ao mesmo tempo um ganho econômico e a restauração da Reserva Florestal Legal, mas que devem existir critérios técnicos que regulamentem as espécies e o tempo de sua exploração. 224

Além disso, há, atualmente, a possibilidade de que a compensação das áreas de Reserva Florestal Legal possa ocorrer em Estados diversos, levando-se em consideração apenas a extensão da área a ser compensada e o bioma em que está inserida.

Mais uma vez a lei florestal recentemente aprovada demonstra o seu retrocesso em relação à proteção ambiental. A compensação levando-se em consideração apenas o bioma no

\footnotetext{
${ }^{224}$ PROPOSTAS E CONSIDERAÇÕES DA SOCIEDADE BRASILEIRA PARA O PROGRESSO DA CIÊNCIA (SBPC) E ACADEMIA BRASILEIRA DE CIÊNCIAS (ABC) ACERCA DA REFORMA DO CÓDIGO FLORESTAL (PLC 30/2011). Disponível em < http://www.sbpcnet.org.br/site/arquivos/Documento\%20SBPCABC\%20para\%20SENADORES\%20anexo\%20168.pdf>. Acessado em 21 de maio de 2012.
} 
qual estão inseridas as áreas de Reserva Florestal Legal não garante a equivalência ecológica dessas áreas. Este é o entendimento da ABC e da SBPC que afirmam ainda que não há também equivalência funcional, visto que os serviços ecossistêmicos prestados por determinada vegetação são restritos à área em que está inserida. Se for para considerar tal possibilidade de composição, que seja ressaltada a necessidade de os biomas serem ecologicamente equivalentes, além de possuírem a mesma composição, estrutura e função. ${ }^{225}$

O Código Florestal de 1965 ao permitir a compensação das áreas de Reserva Florestal Legal exigia que a área a ser utilizada para compensar aquela propriedade devedora de Reserva Florestal Legal deveria ser equivalente em importância ecológica e extensão e deveria ainda pertencer à mesma microbacia ${ }^{226}$ e ao mesmo ecossistema ${ }^{227}$. E caso isto não fosse possível previa um critério subsidiário que seria a localização na mesma bacia hidrográfica e no mesmo Estado, atendendo-se, caso existisse, ao Plano de Bacia Hidrográfica. $^{228}$

Edis Milaré, ao discorrer sobre este assunto com base no Código Florestal de 1965, afirma que caso a compensação da área de Reserva Florestal Legal ocorra em bacias hidrográficas diferentes, aquela aonde a área a ser recomposta está localizada poderá ser prejudicada no que tange à proteção de seus recursos hídricos e, consequentemente, irá atingir um dos objetivos da Política Nacional de Recursos Hídricos, instituída pela Lei $n^{\circ}$. 9.433 de 08-01-1997, qual seja, o de assegurar à atual e às futuras gerações a necessária disponibilidade de água em padrões de qualidade adequados aos respectivos usos, conforme previsto no artigo $2^{\circ}$, inciso I. $^{229}$

Percebe-se, então, que a antiga exigência de que a compensação se desse na mesma microbacia hidrográfica, bem como no mesmo ecossistema, era de suma importância para a

\footnotetext{
${ }^{225}$ PROPOSTAS E CONSIDERAÇÕES DA SOCIEDADE BRASILEIRA PARA O PROGRESSO DA CIÊNCIA (SBPC) E ACADEMIA BRASILEIRA DE CIÊNCIAS (ABC) ACERCA DA REFORMA DO CÓDIGO FLORESTAL (PLC 30/2011). Disponível em < http://www.sbpcnet.org.br/site/arquivos/Documento\%20SBPCABC\%20para\%20SENADORES\%20anexo\%20168.pdf>. Acessado em 21 de maio de 2012.

226 "Microbacias são unidades geográficas naturais onde os fatores ambientais, econômicos e sociais encontram-se em condições homogêneas e, por isso, mais apropriadas para o estabelecimento de plano de uso e manejo, monitoramento e avaliação das interferências humanas no meio ambiente”. GRANZIERA,Maria Luiza Machado. Direito Ambiental. $2^{\mathrm{a}}$ ed. São Paulo: Atlas, 2011. p. 481.

${ }^{227}$ Lei 4.771 de 1965, artigo 44, inciso III, com redação dada pela Medida Provisória $n^{\circ}$. 2.166-67 de 2001, revogado pela Lei $n^{\circ} .12 .651 / 2012$.

${ }^{228}$ Lei 4.771 de 1965 , artigo 44, §4 $4^{\circ}$, incluído pela Medida Provisória nº ${ }^{2} .166-67$ de 2001 e revogado pela Lei nº 12.651/2012.

${ }^{229}$ MILARÉ, Édis. Direito ao meio ambiente: a gestão ambiental em foco: doutrina, jurisprudência, glossário. $7^{\mathrm{a}}$ ed. São Paulo: Revista dos Tribunais, 2011. p. 975.
} 
proteção e conservação dos recursos naturais de determinada região e para a preservação das características ecológicas do respectivo ecossistema.

E não é só. A Lei nº 12.651/2012 introduz, consoante já demonstrado, o conceito de área rural consolidada, assim entendida como a "área de imóvel rural com ocupação antrópica preexistente a 22 de julho de 2008, com edificações, benfeitorias ou atividades agrossilvipastoris, admitida, neste último caso, a adoção de regime de pousio.”230

Essas áreas assim denominadas de áreas consolidadas, conforme observado pela OABRJ, estão isentas do pagamento de multas e desoneradas da obrigação de recompor a área de Reserva Florestal Legal, o que anistia as ilegalidades ocorridas antes de 22 de julho de 2008.231

Isto é, todas as multas aplicada até o marco legal de 22 de julho de 2008 foram perdoadas, bastando, para tanto, que o infrator firme um termo de compromisso de regularização da situação de suas áreas de proteção.

É nesse sentido que a lei prevê que os imóveis rurais com vegetação nativa em percentuais inferiores aos estabelecidos pela lei e que até 22 de julho de 2008 detinham área de até 4 módulos fiscais são desobrigados a recompor a área de Reserva Legal, sendo então considerada como tal a área ocupada com vegetação nativa existente em 22 de julho de 2008.

O Instituto de Pesquisa Econômica Aplicada (IPEA) divulgou um comunicado no qual analisa as alterações no que tange às áreas de Reserva Florestal Legal. Com base na disposição acima citada, o IPEA afirma que 29,6 milhões de hectares se tornariam passivo ambiental, pois não serão recuperados, sendo que a maior parte deste passivo, 61\%, estaria localizado na Amazônia, um dos mais importantes biomas brasileiro.

E, ainda, os proprietários ou possuidores rurais que realizaram a supressão da vegetação nativa em observância aos percentuais exigidos pela lei em vigor à época da supressão também não estarão obrigados a constituir, mediante composição, recomposição ou regeneração, as áreas de Reserva Legal nos percentuais exigidos pelo projeto.

Por fim, a averbação da Reserva Florestal Legal deixou de ser exigida, uma vez que foi substituída pela inscrição no Cadastro Ambiental Rural, o que, por si só, desobriga o proprietário de averbar a área protegida junto à matrícula de seu imóvel.

\footnotetext{
${ }^{230}$ Lei $\mathrm{n}^{\mathrm{o}}$. 12.651 de 25-05-2012, artigo 3ㅇ, inciso IV.

${ }^{231}$ Nota técnica elaborada pela OAB-RJ. Disponível em < http://www.oabrj.org.br/detalheConteudo/217/Nota-tecnicaem-defesa-do-veto-ao-Projeto-de-Lei.html> Acessado em 21 de maio de 2012.
} 
Portanto, diante de todo o exposto, e com base nas manifestações da Associação Brasileira dos membros do Ministério Público do Meio Ambiente (ABRAMPA), Associação dos Professores de Direito Ambiental do Brasil (APRODAB) e dos Institutos Brasileiro de Advocacia Pública e o Direito Por um Planeta Verdade, o texto de lei aprovado vai de encontro às disposições constitucionais relativas ao meio ambiente, bem como às obrigações internacionais assumidas pelo Brasil e, ainda, promove um enorme retrocesso na proteção ambiental.

\subsection{Princípio da Vedação ao Retrocesso}

Conforme demonstrado acima, a Lei $\mathrm{n}^{\circ}$. 12.651/2012 de modo geral representa um retrocesso dos níveis de proteção ambiental em comparação àqueles que eram anteriormente consagrados pelo Código Florestal de 1965.

Por este motivo, cabe mencionar o princípio da vedação ao retrocesso ecológico, o qual, apesar de ainda não muito explorado pela doutrina ambiental brasileira, deverá ser levado em consideração tendo em vista a peculiaridade e a relevância do meio ambiente para os seres humanos.

Este princípio traz a orientação de que não é possível retornar a graus de proteção mais baixos do que aqueles já estabelecidos, isto é, deve-se progredir quando se trata de proteger e garantir um direito fundamental e não regredir, diminuindo a sua proteção e garantia.

Patrick de Araújo Ayala explica que este princípio

“aponta para um proibição da reversão no desenvolvimento dos direitos fundamentais e, para um garantia de não-retorno a graus de proteção que já tenham sido ultrapassados. Por outro lado, também veicularia como efeito uma proibição de reversibilidade dos estágios de desenvolvimento e de proteção de várias realidades existenciais, os quais foram proporcionados, por iniciativa do Estado, a uma determinada sociedade, residindo neste aspecto o principal problema de sua admissão.”232

O princípio da vedação ao retrocesso dos níveis de proteção ambiental já atingidos representa, então, uma garantia do direito fundamental ao meio ambiente ecologicamente equilibrado, ao mesmo tempo em que para aqueles que pretendem estimular o desenvolvimento econômico do país representa um obstáculo, uma vez que não poderão tornar as normas de proteção ambiental mais brandas, tal como foi feito, e por isso pretendem

\footnotetext{
${ }^{232}$ AYALA, Patrick de Araújo. A Proteção dos Espaços Naturais, Mudança Climáticas Globais e Retrocessos Existenciais: Por que o Estdo não tem o direito de Dispor sobre os rumos da existência humana?. In: SILVA, Solange Teles; CUREAU, Sandra; LEUZINGER, Márcia Dieguez. Código Florestal: desafios e perspectivas. São Paulo: Fiuza, 2010. P. 325.
} 
não admitir a existência deste princípio.

A Associação Brasileira dos membros do Ministério Público do Meio Ambiente (ABRAMPA) juntamente com outras entidades ligadas à proteção do meio ambiente divulgaram carta por eles redigidas e encaminhada à Presidente da República na qual solicitavam o veto integral do projeto de lei 1.876 de 1999, que deu origem à Lei $n^{\circ}$. $12.651 / 2012$.

Um dos argumentos utilizados como fundamento do pedido de veto, foi justamente o princípio do retrocesso aos níveis de proteção ambiental. Segundo tais instituições,

"todas as convenções e tratados internacionais de proteção dos direitos humanos favoerecem um sentido de aperfeiçoamento dessa proteção não tendo proposto até o momento, uma única realidade que tenha eliminado, diminuído ou mitigado o conjunto de garantias que já foi atingido no plano internacional.,"233

Além do mais, os dispositivos constitucionais referentes ao meio ambiente transparecem que a proteção já atingida deve ser aperfeiçoada e não diminuída ou até mesmo retirada. Assim, as instituições acima mencionadas ao discorrerem sobre o posicionamento constitucional destacam que a Constituição Federal de 1988 não tolera comportamentos que violem os instrumentos de proteção dos direitos humanos e direcionam a carta à Presidente da República afirmando que

"suas escolhas não podem, desse modo, atingir os limites que definiriam um mínimo existencial ecológico (artigo 225, §1 ${ }^{\circ}$, inciso I), ao mesmo tempo em que devem ser capazes de aperfeiçoar e melhorar os níveis de qualidade de vida e dos recursos naturais que já foram atingidos, em consideração a um imperativo de proteção do bem-estar das futuras gerações (artigo 225, caput). ”234

Portanto, percebe-se que a promulgação da Lei $n^{0}$. 12.651/2012 vai de encontro ao princípio da vedação ao retrocesso ecológico, uma vez que ao revogar o Código Florestal de 1965 trouxe para o meio ambiente brasileiro um nível de proteção abaixo daquele já havia sido à ele concedido, o que representa a tolerância do Estado com comportamentos que de alguma forma agridem o bem ambiental. Pode-se explicar que esta tolerância advém da vontade do governo brasileiro de estimular o seu próprio desenvolvimento econômico, excedendo o limite constitucional a este imposto, já que a proteção e preservação do meio ambiente é um dos fundamentos da ordem econômica brasileira.

\section{Conclusão}

\footnotetext{
${ }^{233}$ Carta da ABRAMPA, APRODAB, IBAP e Instituto “O direito por um planeta verde.” Disponível em www.abrampa.org.br/noticias_listar.php?idNoticia=3783. Acesso em 25 de maio de 2012.

234234 Carta da ABRAMPA, APRODAB, IBAP e Instituto “O direito por um planeta verde.” Disponível em www.abrampa.org.br/noticias_listar.php?idNoticia=3783 Acesso em 25 de maio de 2012.
} 
Há pessoas que não percebem a importância do meio ambiente em suas vidas. Entretanto, a análise da ordem constitucional ambiental permite a conclusão de que a tutela do meio ambiente é extremamente relevante para a sadia qualidade de vida dos seres humanos, tal como dispõe o caput do artigo 225 da Constituição Federal de 1988.

Este artigo erigiu o direito ao meio ambiente à categoria de direito fundamental e dispõe ainda que a relação do meio ambiente com a vida humana é uma relação de essencialidade. Foi essa a palavra escolhida pelo constituinte originário. Essencial quer dizer imprescindível, indispensável, condição principal.

Mas, cumpre ressaltar que não é qualquer meio ambiente que é essencial à qualidade de vida do ser humano, capaz de cumprir com esta função e sim o meio ambiente ecologicamente equilibrado, ou seja, protegido, preservado, conservado.

Percebe-se, então, que a tutela do bem ambiental está direta e intimamente ligada ao direito à vida. Este é um direito inviolável e encontra expressão de diversas formas, não só como o simples direito de estar vivo, mas também como um direito de se ter uma vida saudável, que certamente não será possível sem uma efetiva proteção do meio natural.

A preservação do meio ambiente traduz-se na impossibilidade de degradá-lo, de perturbá-lo. Não se pretende com isso impedir a sua utilização ou o seu aproveitamento. O intuito é resguardá-lo daquela ação humana predatória, que altera as suas funções ecológicas e gera impactos na qualidade da vida humana.

Tais impactos transcendem as fronteiras de cidades, estados e até mesmo de países. Além disso, a recuperação do meio ambiente é geralmente de difícil realização ou até mesmo impossível. Isto traduz a necessidade de se dedicar um cuidado maior e especial a ele, uma vez que a sua utilização de forma irracional pode ser irreversível, traduzindo na necessidade de medidas preventivas, anteriores à ocorrência do dano ambiental.

A sua perturbação em um determinado lugar do mundo poderá afetar os seres humanos que se encontram em outro lugar, distinto e muitas vezes distante. Na verdade, ainda que sejam países diferentes, o lugar habitado por todos é comum, qual seja o planeta Terra e é este que deve receber a atenção especial de toda a humanidade. Por isso é que as normas ambientais devem considerar a extensão das conseqüências dos danos ambientais e não somente os problemas locais por eles ocasionados.

No caso do Brasil, o meio ambiente merece resguardo ainda maior, visto que é um país peculiar no que diz respeito a sua paisagem natural. O Brasil abriga uma das maiores 
biodiversidades do mundo, sendo ainda que boa parte de seu território é coberto por vegetação natural.

É por este motivo que o compromisso brasileiro assumido mundialmente de redução da emissão de gases do efeito estufa tem por base a diminuição do desmatamento das florestas brasileiras, sendo que as leis de proteção a estas sempre foram exemplo mundial.

Nesse contexto, a existência de mecanismos capazes de conceder real proteção à flora brasileira, tal como o faz o instituto da Reserva Florestal Legal, é indispensável, não cabendo contra eles qualquer argumento capaz de retirá-los do ordenamento jurídico brasileiro, ou até mesmo de torná-los mais brandos, principalmente o argumento de que inviabilizam o desenvolvimento econômico.

Conforme restou demonstrado, ainda há no território brasileiro vasta extensão de terra com capacidade produtiva, bastando apenas que se promova a sua recuperação.

A Reserva Florestal Legal deve ser vista como uma medida imprescindível à contenção do desmatamento brasileiro, à proteção da flora brasileira e jamais como um impedimento à produtividade agrícola do país.

Não se devem confundir as terras destinadas à proteção do meio ambiente com as terras destinadas à produção de alimentos. A função de cada uma delas não se mistura e não são incompatíveis.

A adoção do princípio do desenvolvimento sustentável torna plenamente viável a coexistência de preservação ambiental com produtividade e desenvolvimento econômico, bastando apenas que se alterem os padrões de consumo dominantes e as técnicas de produção, bem como se inserindo na comunidade brasileira a conscientização ambiental.

Não obstante, a legislação florestal brasileira foi significativamente alterada e tais alterações representaram um enorme retrocesso no que tange à proteção ambiental.

A revogação do Código Florestal ocorreu sem que se observassem as peculiaridades do bem ambiental. Não houve um diálogo entre os diversos setores da sociedade brasileira. Mas, ainda assim, diversas entidades e instituições apresentarem suas manifestações contrárias às modificações que foram introduzidas e isto demonstra o quão inadequado foi a revogação da lei florestal.

O instituto da Reserva Florestal Legal, conforme demonstrado, foi um dos instrumentos de proteção florestal que sofreu alterações negativas, isto é, que foi alterado no 
sentido de ser flexibilizando, criando espaço para novos desmatamentos e menos áreas de proteção florestal.

Portanto, pretendeu-se com o presente trabalho demonstrar a importância do meio ambiente para a humanidade e o papel fundamental desempenhado pelo instituto da Reserva Florestal Legal na concretização do direito ao meio ambiente ecologicamente equilibrado, bem como contestar as modificações que sofreu com a revogação do Código Florestal.

\section{Bibliografia}

- MILARÉ, Édis. Direito do Ambiente: A gestão ambiental em foco: Doutrina, 
jurisprudência, Gloassário. 7ª Ed. São Paulo: Revista dos Tribunais, 2011.

- CARADORI, Rogério da Cruz. O Código Florestal e a legislação extravagante: a teoria e a prática da proteção florestal. São Paulo: Atlas, 2009.

- GRANZIERA, Maria Luiza Machado. Direito Ambiental. 2ª Ed. São Paulo: Atlas, 2011.

- BOFF, Leonardo. Ethos Mundial: um consenso mínimo entre os humanos. Rio de Janeiro: Record, 2009.

- SILVA, José Afonso da. Direito Ambiental Constitucional. 9a Ed. São Paulo: Malheiros, 2011.

- SANCHÉZ, Luis Enrique. Avaliação de Impacto Ambiental: métodos e conceitos. São Paulo: Oficina dos Textos, 2008.

- MACHADO, Paulo Affonso Leme. Direito Ambiental Brasileiro. 14ª Ed. São Paulo: Malheiros, 2006.

- FERREIRA, Heline Sivini. Política Ambiental Constitucional. In: CANOTILHO, José Joaquim Gomes; LEITE, Rubens Morato (org.). Direito constitucional ambiental brasileiro.

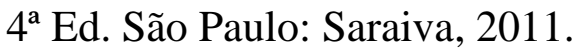

- FERREIRA, Heline Sivini. Competências Constitucionais. In: CANOTILHO, José Joaquim Gomes; LEITE, Rubens Morato (org.). Direito constitucional ambiental brasileiro. $4^{\mathrm{a}}$ Ed. São Paulo: Saraiva, 2011.

- ANTUNES, Paulo de Bessa. Direito Ambiental. 12ª Ed. Rio de Janeiro: Lumen Júris, 2010.

- SILVA, Solange Teles da; CUREAU, Sandra; LEUZINGER, Márcia Dieguez, coordenação. Código Florestal: desafios e perspectivas. São Paulo: Fiúza, 2010.

- COSTA NETO, Nciolado Dino de Castro. Proteção Jurídica do Meio Ambiente: florestas. Belo Horizonte: Del Rey, 2003.

- MORAES, Alexandre. Direitos Humanos Fundamentais: teoria geral: comentários aos artigos $1^{\circ}$ a $5^{\circ}$ da Constituição da República Federativa do Brasil: doutrina e jurisprudência. 9a Ed. São Paulo: Atlas, 2011.

- AMADO, Frederico Augusto Di Trindade. Direito Ambiental esquematizado. $2^{\mathrm{a}}$ Ed. Rio de Janeiro: Forensa; São Paulo: Método, 2011.

- REALE, Miguel. Lições preliminares de direito. 27ª Ed. São Paulo: Saraiva, 2002.

- GUERRA, Isabella Franco; LIMMER, Flávia C. Princípios Constitucionais Informadores do Direito Ambiental. In: PEIXINHO, Manoel Messias, GUERRA, Isabella Franco; 
NASCIMENTO FILHO, Firly (orgs.). Os princípios da Constituição de 1988. Rio de Janeiro: Lumen Júris, 2006.

- LENZA, Pedro. Direito Constitucional esquematizado. 14ª Ed. São Paulo: Saraiva, 2010.

- DI PIETRO, Maria Sylvia Zanella. Direito Administrativo. 25ª Ed. São Paulo: Atlas, 2012.

- LINHARES, Sérgio; GEWANDSZNAKDER, Fernando. Biologia hoje: volume 3. $10^{\mathrm{a}}$ Ed. São Paulo: Ática, 1999.

- HOUAISS, Antônio; VILLAR, Mauro de Salles, Dicionário Houaiss da Língua Portuguesa. $1^{\text {a }}$ ED. Rio de Janeiro: Objetiva, 2001.

- SILVA, José Afonso da. Curso de Direito Constitucional Positivo. 27a Ed. São Paulo: Malheiros, 2006.

- LEITE, José Rubens Morato. Sociedade de Risco e Estado. In: CANOTILHO, José Joaquim Gomes; LEITE, Rubens Morato (org.). Direito constitucional ambiental brasileiro. $4^{\mathrm{a}}$ Ed. São Paulo: Saraiva, 2011.

- AYALA, Patrick de Araújo. A Proteção dos Espaços Naturais, Mudança Climáticas Globais e Retrocessos Existenciais: Por que o Estdo não tem o direito de Dispor sobre os rumos da existência humana?. In: SILVA, Solange Teles; CUREAU, Sandra; LEUZINGER, Márcia Dieguez. Código Florestal: desafios e perspectivas. São Paulo: Fiuza, 2010. P. 325.

- Indicadores de Desenvolvimento Sustentável 2010. IBGE. p. 82, 89 e 96. Disponível em http://www.ibge.gov.br/home/geociencias/recursosnaturais/ids/ids2010.pdf Acesso em 25 de maio de 2012.

- Bioma Mata Atlântica encolheu 13 mil hectares. O Eco. Disponível em http://www.oeco.com.br/noticias/26057-bioma-mata-atlantica-encolheu-13-mil-hectares Acesso em 30 de maio de 2012.

- STF, ADI nº. 3540/DF, Relator Ministro Celso de Mello, Brasília, 01 de setembro de 2005.

- Declaração de Estocolmo (1972). Princípio 1. Ministério do Meio Ambiente. Disponível em HTTP://www.mma.gov.br/estruturas/agenda21/_arquivos/estocolmo.doc Acesso em 19 de abril de 2012.

- Declaração do Rio sobre Meio Ambiente e Desenvolvimento. Princípio 1. Ministério do Meio Ambiente. Disponível em HTTP://www.mma.gov.br/sitio/index.php?ido=conteudo.monta\&idEstrutura=18\&idConteud $\underline{\mathrm{o}=576}$ Acesso em 19 de abril de 2012.

- Relatório Brudtland e a sustentabilidade. Mudanças Climáticas. Disponível em HTTP://www.mudancasclimaticas.andi.org.br/node/91 Acesso em 07 de maio de 2012. 
- PROPOSTAS E CONSIDERAÇÕES DA SOCIEDADE BRASILEIRA PARA O PROGRESSO DA CIÊNCIA (SBPC) E ACADEMIA BRASILEIRA DE CIÊNCIAS (ABC) ACERCA DA REFORMA DO CÓDIGO FLORESTAL (PLC 30/2011). Disponível em < http://www.sbpcnet.org.br/site/arquivos/Documento\%20SBPCABC\%20para\%20SENADORES\%20anexo\%20168.pdf>. Acessado em 21 de maio de 2012.

- Contribuições da ABC e da SBPC para o debate sobre o Código Florestal. Sociedade Brasileira para o Progresso da Ciência. Disponível em <

http://www.sbpcnet.org.br/site/arquivos/arquivo_295.pdf> Acesso em 25 de maio de 2012.

- Carta da ABRAMPA, APRODAB, IBAP e Instituto “O direito por um planeta verde.” Disponível em <http:// www.abrampa.org.br/noticias_listar.php?idNoticia=3783> Acesso em 30 de maio de 2012.

- Nota técnica elaborada pela OAB-RJ. Disponível em $<$ http://www.oabrj.org.br/detalheConteudo/217/Nota-tecnica-em-defesa-do-veto-ao-Projetode-Lei.html>. Acessado em 21 de maio de 2012.

- Supremo Tribunal Federal. ADPF nº 101/DF. Relator Ministra Carmen Lúcia, Brasília, 24 de junho de 2009.

- Superior Tribunal de Justiça. Recurso Especial nº 1116964/PI. Relator Ministro Mauro Campbell Marques, Brasília, 15 de março de 2011.

- Supremo Tribunal Federal, ACO nº 876 MC-Agr/BA, Relator Ministro Menezes Direito, Brasília, 19 de dezembro de 2007.

- Tribunal de Justiça do Estado do Rio de Janeiro. Agravo de Instrumento $n^{0}$. 0004469-702012.8.19.0000. Desembargador Elton Leme. Rio de Janeiro, 16 de fevereiro de 2012.

- Superior Tribunal de Justiça. Recurso Especial nº 948.921/SP. Relator Ministro Herman Benjamin. Brasília, 23 de outubro de 2007.

- Supremo Tribunal Federal, ADPF nº 101/DF, Relatora Ministra Carmen Lúcia, Brasília, 24 de junho de 2009.

- Superior Tribunal de Justiça. Recurso Especial nº. 1179.316/SP, Relator Ministro Teoria Albino Zavascki, Brasília, 15 de junho de 2010.

- Amazônia Legal, Disponível wm HTTP://pt.wikipedia.org/wiki/Amazônia_Legal Acesso em 25 de maio de 2012.

- Superior Tribunal de Justia. Recurso Especial nº 1060886/PR. Relator Ministro Luiz Fux, Brasília, 01 de dezembro de 2009. 
- Superior Tribunal de Justiça, Recurso Especial nº. 1125632/PR, Relator Ministro Benedito Gonçaves, Brasília, 20 de agosto de 2009. 